\title{
Upper Frasnian Tornoceratidae (Ammonoidea) from the Sand Formation (Bergisch Gladbach-Paffrath Syncline, Rhenish Massif)
}

\author{
Till Söte ${ }^{1}\left(\mathbb{D} \cdot\right.$ Ralph Thomas Becker $^{1} \cdot$ Karl Josef Herd $^{2} \cdot J_{\text {ürgen Bockwinkel }}^{3}$
}

Received: 30 March 2020 / Accepted: 29 December 2020 / Published online: 28 May 2021

(c) The Author(s) 2021

\begin{abstract}
Excavations in the Sand district of Bergisch Gladbach (Rhenish Massif, Germany) yielded a rich ammonoid fauna of the upper Frasnian "Archoceras" varicosum Zone (Upper Devonian I-K, interval between the two Kellwasser levels). The previously unknown assemblages include six tornoceratid genera with 20 species, including seven new species (Aulatornoceras steinhauseni sp. nov., Aul. frenklerae sp. nov., Aul. ventrosulcatum sp. nov., Crassotornoceras nudum sp. nov., Cr. hetzeneggeri sp. nov., Retrotornoceras juxi sp. nov., Tornoceras aequilobum sp. nov.) and taxa described in open nomenclature. There are five associated gephuroceratid genera with nine species. The unexpectedly high genus- and species-level diversity at Sand, supported by statistical indices, is unprecedented compared to other contemporaneous ammonoid faunas. It highlights the currently fragmentary knowledge of top-Frasnian ammonoid faunas on a global scale. Phoenixites frechi, the dominant tornoceratid of hypoxic and organic-rich Kellwasser facies of Europe and North Africa, is completely missing at Sand. The local assemblage structure is analyzed statistically and interpreted in terms of palaeoecology. The occurrence of a new type of "Housean Pits", probably caused by parasitism, is found in nine species of five genera, mostly in tornoceratids. The Sand fauna indicates that the species origination rate in tornoceratids remained high after the Lower Kellwasser Event.
\end{abstract}

Keywords Ammonoidea $\cdot$ Goniatitida $\cdot$ Upper Devonian · Frasnian $\cdot$ Rhenish Massif $\cdot$ Kellwasser Crisis

\section{Introduction}

The upper Frasnian Kellwasser Crisis was a 1st order global extinction event (e.g., Raup and Sepkoski 1982; Schindler 1990; Racki 2005; De Vleeschouwer et al. 2017; Carmichael et al. 2019), which was especially severe in pelagic organism groups, and notably in ammonoids (e.g., Becker 1993a, b; Becker and House 1993, 1994). Whilst the order Agoniatida (suborder Gephuroceratina) was wiped out completely, five lineages of the Tornoceratidae (Goniatitida, Tornoceratina) survived. However, all groups apart from the genus Phoenixites (Falcitornoceratinae), the Tornoceratinae (Tornoceras,

Handling Editor: Christian Klug.

Till Söte

t_soet01@uni-muenster.de

1 Institut für Geologie und Paläontologie, Westfälische Wilhelms-Universität Münster, Corrensstraße 24, 48149 Münster, Germany

2 Am Gartenfeld 66, 51519 Odenthal-Holz, Germany

3 Dechant-Feinstraße 22, 51375 Leverkusen, Germany
Linguatornoceras, Crassotornoceras) and Aulatornoceratinae (Aulatornoceras), were affected to such an extent that they disappeared from the fossil record for at least five conodont zones (until the Pa. glabra prima Zone) and therefore representing Lazarus taxa (Flessa and Jablonski 1983; Jablonski 1986; Fara 2001; Schneider 2018).

Various authors claimed that the Kellwasser Crisis is better characterized by a significant reduction of speciation rates, rather than by elevated extinctions, leading indirectly to an absolute decrease in biodiversity (e.g., Bambach et al. 2004; Stigall 2012). In this context, the study of upper Frasnian goniatites, and especially of tornoceratids, becomes an important topic. The revision of old faunas and the description of new and partly rich assemblages enables to clarify aspects of regional and global diversity as well as the timing and patterns of extinctions, survival, and originations. Only detailed morphological comparisons can address the question of whether supposed representatives of upper Frasnian and lower Famennian taxa indeed belonged to single species or whether there was a morphological and taxonomic change in the intervening Lazarus phases. 
Within the Rhenish Massif, the Bergisch GladbachPaffrath Syncline is one of the classical areas for Devonian palaeontology and stratigraphy. It is long-known to the geological community, with earliest research dating back to the eighteenth century (Beuth 1776; Schröter 1777). However, even today substantial gaps of knowledge exist and require ongoing palaeontological research. One of these gaps is the long neglected goniatite fauna of the upper Frasnian Sand Formation. Some specimens have been briefly mentioned in the past but without any taxonomic investigation or documentation (e.g., Jux 1967). Mostly based on unpublished collections by $\mathrm{KJH}, \mathrm{HF}$, and $\mathrm{HS}$, we present a comprehensive survey of the rich and unexpectedly diverse Sand ammonoid fauna, with a focus on the tornoceratids. The results of our study provide a first step towards an understanding of upper Frasnian tornoceratid diversity, extinction, and origination rates. Future steps will concentrate on further unpublished faunas from the eastern Rhenish Massif (e.g., Martenberg), the Eifel Mountains (Büdesheim), and Morocco (Dra Valley, Tafilalt/Maider regions, Meseta).

Abbreviations Ammonoids-"Arch." = "Archoceras", Aul. $=$ Aulatornoceras, $C r .=$ Crassotornoceras, Crick. $=$ Crickites, G. $=$ Goniatites, Lob. $=$ Lobotornoceras, Ling. $=$ Linguatornoceras, $M .=$ Manticoceras, Ph. $=$ Phoenixites, Retro. $=$ Retrotornoceras, Serra.$=$ Serramanticoceras, Sphaero. $=$ Sphaeromanticoceras, $T .=$ Tornoceras, $\mathrm{UD}=$ Upper Devonian, with the ammonoid zonal key of Becker and House (2000a); Conodonts $-A .=$ Ancyrognathus, Pa. $=$ Palmatolepis, Po. $=$ Polygnathus .

\section{Studied section}

The investigated locality is situated at the Herkenrather Straße 70 in the Bergisch Gladbach-Sand district (topographic sheet 5009 Overath; GPS $50^{\circ} 59^{\prime} 18.1^{\prime \prime} \mathrm{N}, 7^{\circ} 09^{\prime}$ $40.9^{\prime \prime}$ E). This area belongs to the Bergisch Gladbach-Paffrath Syncline and lies just E of the Rhine river. During short times in 2003, 2009, 2012 and 2013, excavations for the construction of a supermarket and for an enlargement of its parking lots opened several outcrops of the Sand Formation (Fig. 1). Weber et al. (2013) provided an overview of the fauna collected there. The younger excavations yielded most of the goniatite fauna investigated herein. There is no detailed section log since intensive tectonics (variable strike directions) hindered a simple stratigraphic correlation (Weber et al. 2013). Goniatites come from five of the six collecting sites named as Sand 1 to 5 and Sand A (Fig. 1). The occurrences of individual taxa at each spot are marked in Table 1. Based on the overall dip in the Bergisch GladbachPaffrath Syncline, the more northern collecting spot (Sand 4) should be slightly older than the middle and more southern spots (Sand 3A to 3C and Sand A). In autumn 2019, two laminated marly limestone beds from just S of Sand A were sampled for conodonts. Apart from isolated specimens of Po. alatus, Pa. hassi, and A.triangularis, the samples lacked conodonts. The associated microfauna is rich in entomozoid ostracods, including Entomozoe (Nehdentomis) pseudorichterina. However, there are no forms with concentric ornament that could provide a precise placing in the very detailed upper Frasnian entomozoid zonation. Additionally, the samples yielded orthoconic cephalopods and some juvenile ammonoids.

Rare goniatites of the Sand Formation occur at six other localities: (1) The type locality of the formation at forested streams between Halfen-Dombach and Plätz, ca. $700 \mathrm{~m} \mathrm{~W}$ of the Herkenrather Straße 70. (2) E of Breite, at a forested stream ca. $1.3 \mathrm{~km}$ E of the Herkenrather Straße 70. (3) SW of Wesselsteinbach, at forested streams between Sand and Herkenrath. (4) At the escarpment of the Lerbach brook W of Kaltenbroich and ca. $800 \mathrm{~m}$ SSE of the Herkenrather Straße 70. (5) At the former construction site at Herkenrather Straße 59-61, directly opposite of Herkenrather Straße 70. (6) At the base of the Kreishaus section ca. $2.4 \mathrm{~km} \mathrm{SW}$ of the Herkenrather Straße 70.

The only currently accessible collecting spot is locality 4 at the Lerbach brook. Isolated specimens that cannot be placed in the new succession are listed in Table 1 in the "+" column.

\section{Research history}

Fliegel (1923: 379) was the first to recognize a separate "Mergelschiefer-Stufe" on top of the Hombach Formation, a unit which is roughly correlatable with the Sand Formation. The term "Sander Schichten" was coined much later by Jux and Groos (1967) for sandy and marly shales, including 5-10 m thick, black, bituminous, calcareous "Kellwasser shales" at the top. In the same year, Jux (1967) described the dendroid graptolite ?Palaeodictyota montana (see Hartkopf-Fröder and Weber 2016 for a paratype) from the Sand Formation and mentioned the occurrence of several goniatites belonging to Tornoceras and Manticoceras. Despite a focus on the overlying, lower Famennian Knoppenbissen Formation, Jux and Krath (1974) noticed several fossil groups (e.g., tentaculitoids, ostracods, goniatites, bivalves, and crinoids) and bitumen-bearing calcareous geodes in the Sand Formation. In the annotations to the geological map of sheet Overath, Jux (1982) provided a useful overview of the latter. Jux (1984) focused on acritarch communities in the Bergisch Gladbach area and recognized a diversity peak (more than 40 species) in the Sand Formation. Amirie (1984, 1989) also reported acritarch populations, dominated by baltisphaerids. Queins (1988) studied tentaculitoids and 


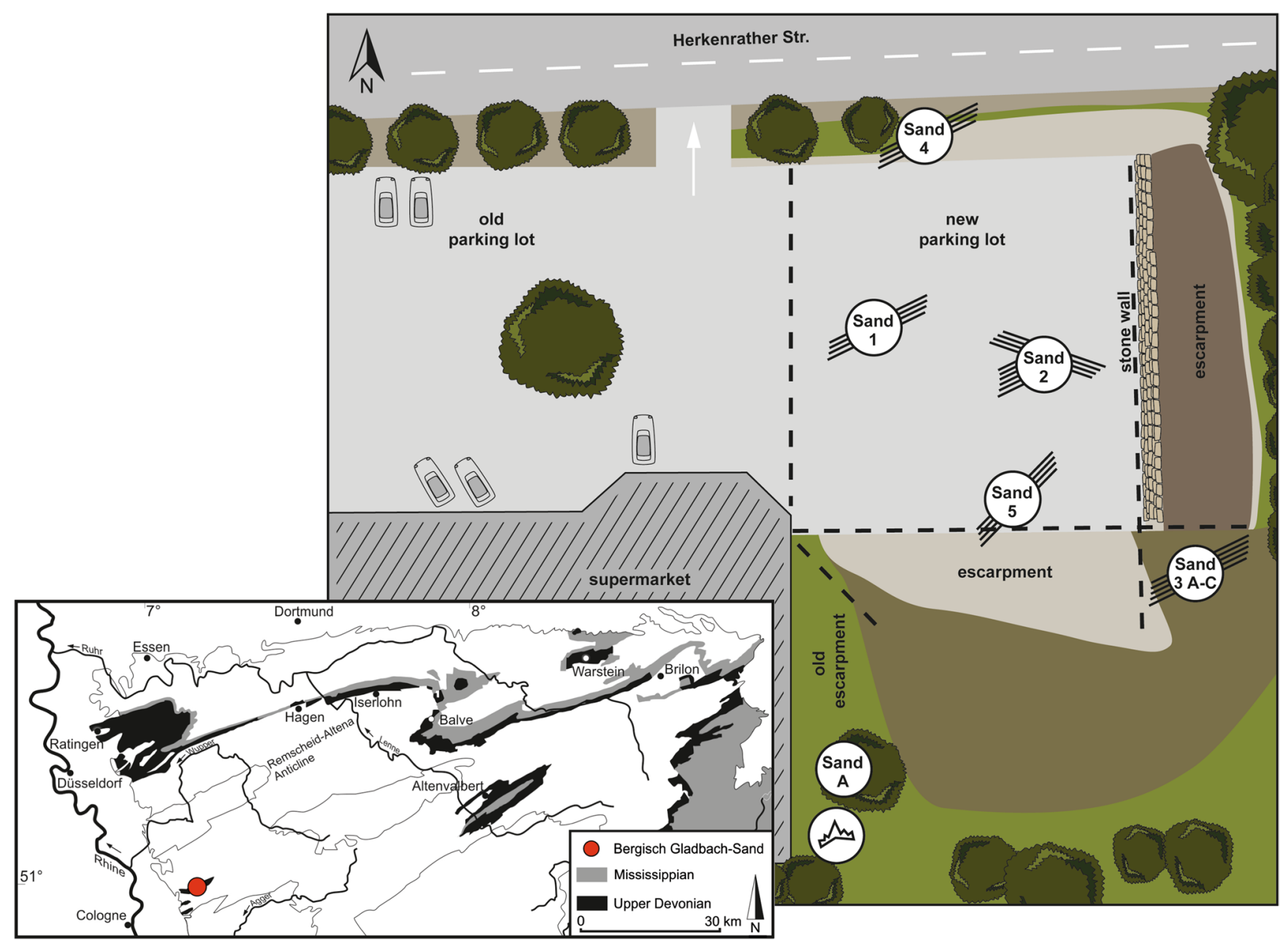

Fig. 1 Collecting spots of goniatites and conodont samples in the Sand Formation of Bergisch Gladbach-Sand (Herkenrather Straße 70: small-scale map of the supermarket and new parking lots) in the frame of the geological map of the northern Rhenish Massif. The general dip of the Bergisch Gladbach-Paffrath Syncline is to the SSE, with the oldest collecting spots in the NNW
Kleinebrinker (1992) conodonts and the coalification of the Devonian of Bergisch Gladbach. An unpublished field trip guidebook by Jux (1991) also describes the Sand Formation and includes a correlation with the topFrasnian Upper Kellwasser beds. Three summaries of the Sand Formation and of the Bergisch Gladbach-Paffrath Syncline, in general, were published by Hartkopf-Fröder et al. (2004), Jux (2008), and Ribbert (2012). HartkopfFröder et al. (2004) provided a regional geological map. Korn et al. (2013) described goniatites from Büdesheim (Eifel) but also mentioned one specimen of "Archoceras" from Sand (leg. KJH; specimen MB.C.29344). Most recently, Hartkopf-Fröder and Weber (2016) outlined the palaeogeographical and facies evolution of the Bergisch Gladbach-Paffrath Syncline, which included data on the Sand Formation.

\section{Stratigraphy and facies}

According to Piecha (2004), the approximately $30 \mathrm{~m}$ thick Sand Formation ranges from the Pa. jamieae to the upper $P a$. linguiformis Zone. The conodont evidence is, however, weak. Kleinebrinker (1992) recorded Pa. foliacea, Pa. gigas, and the long-ranging Po. webbi. The first species enters high in the Pa. feisti Zone (upper MN Zone 11 sensu Klapper 1989) and ranges to the base of the Pa. bogartensis Zone (basal MN Zone 13a, Klapper and Kirchgasser 2016). The second refers to a junior synonym of $P a$. winchelli (or $P a$. subrecta), which ranges from the base of the Pa. winchelli Zone (base MN 12 Zone) right to the Frasnian-Famennian boundary. Our new samples add Pa. hassi, A. triangularis, and Po. alatus to the conodont faunal list. The first ranges from higher parts of the middle to the top of the Frasnian, the second characterizes 
Table 1 Species list of the 11 goniatite genera and 30 species recorded so far from Bergisch Gladbach-Sand (with references to figured representatives of taxa that are not treated in the systematic chapter) and occurrences of taxa at the individual collecting spots

\begin{tabular}{|c|c|c|c|c|c|c|c|c|c|c|}
\hline Tornoceratoidea & 4 & 1 & 2 & 3 & $3 \mathrm{~A}$ & $3 \mathrm{~B}$ & $3 \mathrm{C}$ & A & + & $\sum$ \\
\hline Aulatornoceras auris (Quenstedt, 1846) & - & 5 & - & - & - & - & - & 1 & - & 6 \\
\hline Aulatornoceras constrictum (Steininger, 1849) & - & - & - & - & - & - & - & 6 & - & 6 \\
\hline Aulatornoceras aff. constrictum (Steininger, 1849) & - & 1 & - & - & - & - & - & - & - & 1 \\
\hline Aulatornoceras eifliense (Steininger, 1849) & - & - & - & 1 & - & - & - & 4 & 3 & 8 \\
\hline Aulatornoceras steinhauseni sp. nov. & - & 4 & - & - & - & - & - & - & - & 4 \\
\hline Aulatornoceras frenklerae sp. nov. & 1 & - & - & - & - & 2 & - & 1 & - & 4 \\
\hline Aulatornoceras ventrosulcatum sp. nov. & - & 1 & - & - & - & - & - & - & 1 & 2 \\
\hline Aulatornoceras aff. ventrosulcatum & - & 1 & - & - & - & - & - & - & - & 1 \\
\hline Aulatornoceras sp. & - & 1 & - & - & - & - & - & 1 & - & 2 \\
\hline Crassotornoceras crassum (Matern, 1931a) & 2 & - & - & 1 & - & 1 & - & 8 & - & 12 \\
\hline Crassotornoceras belgicum (Matern, 1931b) & - & - & - & - & 1 & - & 1 & 5 & 2 & 9 \\
\hline Crassotornoceras aff. belgicum (Matern, 1931b) & - & - & - & - & - & - & - & 1 & - & 1 \\
\hline Crassotornoceras nudum sp. nov. & 1 & - & - & - & - & - & - & 3 & - & 4 \\
\hline Crassotornoceras hetzeneggeri sp. nov. & - & - & - & 1 & - & - & - & 3 & - & 4 \\
\hline Crassotornoceras sp. & - & 1 & - & 1 & 1 & - & - & 4 & 1 & 8 \\
\hline Linguatornoceras cf. clausum (Glenister, 1958) & 1 & - & - & 1 & - & - & - & 1 & - & 3 \\
\hline $\begin{array}{l}\text { Linguatornoceras linguum } \\
\text { (Sandberger and Sandberger, 1851) }\end{array}$ & 4 & - & - & 1 & - & - & - & 7 & - & 12 \\
\hline $\begin{array}{l}\text { Linguatornoceras sp. } 1 \\
\text { (Sandberger and Sandberger, 1851) }\end{array}$ & - & - & - & - & - & - & - & 1 & - & 1 \\
\hline Lobotornoceras ausavense (Steininger, 1849) & - & - & - & 2 & - & - & - & 1 & - & 3 \\
\hline Retrotornoceras juxi sp. nov. & 1 & - & - & - & - & - & - & - & - & 1 \\
\hline Tornoceras holwilli (House, 2002) & - & - & - & 3 & 2 & 2 & 1 & 3 & - & 11 \\
\hline Tornoceras aequilobum sp. nov. & 2 & - & - & 1 & - & - & - & 3 & - & 6 \\
\hline Tornoceras sp. & - & - & - & 1 & - & 1 & - & - & - & 2 \\
\hline Gephuroceratoidea & 4 & 1 & 2 & 3 & $3 \mathrm{~A}$ & $3 \mathrm{~B}$ & $3 \mathrm{C}$ & A & + & $\Sigma$ \\
\hline $\begin{array}{l}\text { "Archoceras" varicosum (Drevermann, 1901) } \\
\text { (Fig. 2n, cf. Fig. 2o-p) }\end{array}$ & 1 & - & - & - & 1 & 3 & - & 8 & - & 13 \\
\hline "Archoceras" sp. & - & - & - & 1 & 1 & - & - & 1 & - & 3 \\
\hline Clauseniceras sp. 1 (Figs. 2q, 3a) & - & - & - & - & - & - & - & 3 & - & 3 \\
\hline $\begin{array}{l}\text { Manticoceras aff. lamed } \\
\text { (Sandberger and Sandberger, 1851) (Fig. 3b-c) }\end{array}$ & 1 & - & - & - & - & 5 & - & 6 & - & 12 \\
\hline $\begin{array}{l}\text { Manticoceras cordatum } \\
\text { (Sandberger and Sandberger, 1851) (Fig. 3d-f) }\end{array}$ & - & - & 2 & 6 & 10 & 3 & - & 4 & - & 25 \\
\hline $\begin{array}{l}\text { Manticoceras drevermanni Wedekind, } 1913 \\
\text { (Fig. } 3 \mathrm{~g}-\mathrm{h} \text { ) }\end{array}$ & - & - & - & - & - & - & - & - & 3 & 3 \\
\hline Manticoceras sp. & 2 & - & - & 1 & 7 & 1 & - & 2 & 1 & 14 \\
\hline $\begin{array}{l}\text { Serramanticoceras serratum (Steininger, 1849) } \\
\text { (Fig. 31-o) }\end{array}$ & - & - & 1 & 5 & 6 & 11 & - & 2 & - & 25 \\
\hline $\begin{array}{l}\text { Serramanticoceras cf. obliquesulcatum (Clausen, } \\
\text { 1969) (Fig. 3p) }\end{array}$ & - & - & - & - & - & 1 & - & - & - & 1 \\
\hline Serramanticoceras sp. & - & - & - & 1 & 1 & 1 & - & - & - & 3 \\
\hline $\begin{array}{l}\text { Sphaeromanticoceras affine (Steininger, 1849) } \\
\text { (Fig. 3i) }\end{array}$ & - & - & - & 2 & 3 & 3 & 1 & 3 & - & 12 \\
\hline $\begin{array}{l}\text { Sphaeromanticoceras orbiculum (Beyrich, 1837) } \\
\text { (Fig. } 3 \mathrm{j}-\mathrm{k} \text { ) }\end{array}$ & 1 & - & - & 3 & - & 3 & - & - & - & 7 \\
\hline Sphaeromanticoceras sp. & 1 & - & - & - & 2 & 3 & - & 2 & - & 8 \\
\hline
\end{tabular}

all of the upper Frasnian, and the third ranges through the complete Frasnian (e.g., Klapper 1997). Therefore, the new samples do not constrain the age of the formation and of our goniatite faunas to a discrete conodont zone. It is well possible that the Sand Formation includes all of the upper Frasnian (sensu Becker and House 1999) since the underlying Hombach Formation lacks any upper Frasnian conodonts or goniatites (Hartkopf-Fröder and Weber 2016). 
The lower half of the Sand Formation differs from the underlying strata by the lack of regularly occurring limestone beds. These are replaced by greyish to brownish shales and marls including some concretionary limestone layers (Hartkopf-Fröder et al. 2004). Prominent black calcareous shales and laminated marly horizons mark the upper Sand Formation and represent the Upper Kellwasser beds (Jux and Groos 1967). The macrofauna of the Sand Formation is not abundant but diverse. It consists of inarticulate (lingulids) and articulate brachiopods, goniatites (including anaptychi), tentaculitoids (homoctenids and dacryoconarids), ostracods (mostly entomozoaceans), orthoconic cephalopods, gastropods, bivalves ("Buchiola" and Guerichia), crinoids, dendroid graptolites, trilobites, rare wood remains, and even deep-water rugose corals (e.g., Jux 2008; Weber et al. 2013). Although microfossils have been neglected, many groups are known, such as ostracods, conodonts, acritarchs, other palynomorphs, sponge spicules, and radiolarians (e.g., Jux 2008; Weber et al. 2013). Ammonoids and other molluscs are preserved as small-sized pyritic moulds, which changed during diagenesis into iron oxides, leading to a wide range of brown to bluish secondary colors. The best-preserved specimens are characterized by surrounding, white crystalline seams that have to be removed by mechanical preparation. Most levels are rich in anaptychi with preserved organic films, while large-sized goniatites are almost lacking. As an exception, there was a large fragmentary, calcareous Manticoceras body chamber, in which many smaller, juvenile goniatites were washed in.

In agreement with Kleinebrinker (1992), the environment during the deposition of the Sand Formation was a quiet, distal, outer shelf basin with poor ventilation. Oxygen levels were sufficient to support at least episodically the settlement of a restricted deep-water benthos assemblage. There is no evidence of any photic zone faunal elements or of storm deposition.

Based on the presence of its index species at the most northern, supposedly oldest collecting spot (Sand 4), the complete Sand goniatite fauna is assigned to the "Archoceras" varicosum Zone (Fig. 4; UD I-K sensu Becker and House 1993, 1994, 2000a). This zone starts with the Lower Kellwasser level (Fig. 4; top Pa. winchelli Zone or MN Zone 12, Becker et al. 1993) and ranges to a level in the lower part of the Pa. bogartensis Zone (lower MN Zone 13a). There is no evidence for early Crickites species at Sand, which define the lower part of UD I-L (Crickites genozone, see Fig. 4). However, Crick. holzapfeli, the index species of UD I- $\mathrm{L}_{2}$, has been reported from the Upper Kellwasser level at the top of the Sand Formation (Jux and Krath 1974), from well above our collecting level and far from localities in Sand (Kreishaus section; see spot 6 of the other localities listed above). Based on the association with $M$. drevermanni, older collections from the Sand Formation are also assigned to the upper Frasnian. The type-level of $M$. drevermanni is in the Upper Kellwasser Limestone of Bicken (Wedekind 1913) but relatives enter elsewhere much earlier (UD I-I in the Canning Basin, Becker and House 2009).

\section{Ammonoid diversity and palaeoecology}

The Sand goniatite fauna is characterized by a high alpha diversity (local species richness), which, on a global scale, is only rivalled by the so far incompletely documented Büdesheim Shale faunas (e.g., Clausen 1969; Korn et al. 2013). The eutrophic facies at Sand sustained an unusually diverse population, which was obviously only partially affected by the hypoxic bottom conditions. This resembles goniatite faunas from lower Famennian hypoxic goniatite shales, such as the overlying Knoppenbissen Formation (Jux and Krath 1974; Weber 2016) or from the famous Nehden Goniatite Shale of the eastern Sauerland (Becker 1993a; Becker et al. 2016).

The total number of Sand ammonoid specimens identified at the genus level is 240 and 200 at the species level. The assemblage structure is relatively evenly distributed between members of the Tornoceratoidea $(46.25 \%)$ and Gephuroceratoidea (53.75\%). This differs significantly from upper Frasnian oxic cephalopod limestones, where Gephuroceratoidea are much more dominant (e.g., Rhenish Massif: Wedekind 1913; Matern 1931a; House and Ziegler 1977; Montagne Noire: Becker and House 1994; Timan: Bogoslovskiy 1969; Becker et al. 2000; Rudnyi Altai: Bogoslovskiy 1969; Western Australia: Becker and House 2009). Based on the number of specimens assigned at the species level (not corrected) and on an approach of relative abundance (corrected), which includes statistical projections of specimens allocated to genera only, we calculated the Shannon diversity index $(H)$, the Pilou's evenness $(J)$, and the Simpson diversity index $(D)$.

The Shannon diversity index $(H)$ is given by the following formula (Shannon 1948; Spellerberg and Fedor 2003):

$H=-\sum_{i=1}^{s} p_{i} \times \ln p_{i}$

with $p_{i}=\frac{n_{i}}{n}$.

For the complete Sand fauna, $H$ varies only slightly between 3.00 (not corrected) and 2.97 (corrected), with $H_{\max }=\ln (s)=3.37, s=$ number of species, and $n=$ number of specimens.

The typical value of $H$ ranges between 1.5 and 3.5 and is rarely greater than 4 . Due to our alpha diversity of 29 taxa, our value of $H$ can not exceed 3.37. However, $H$ is 


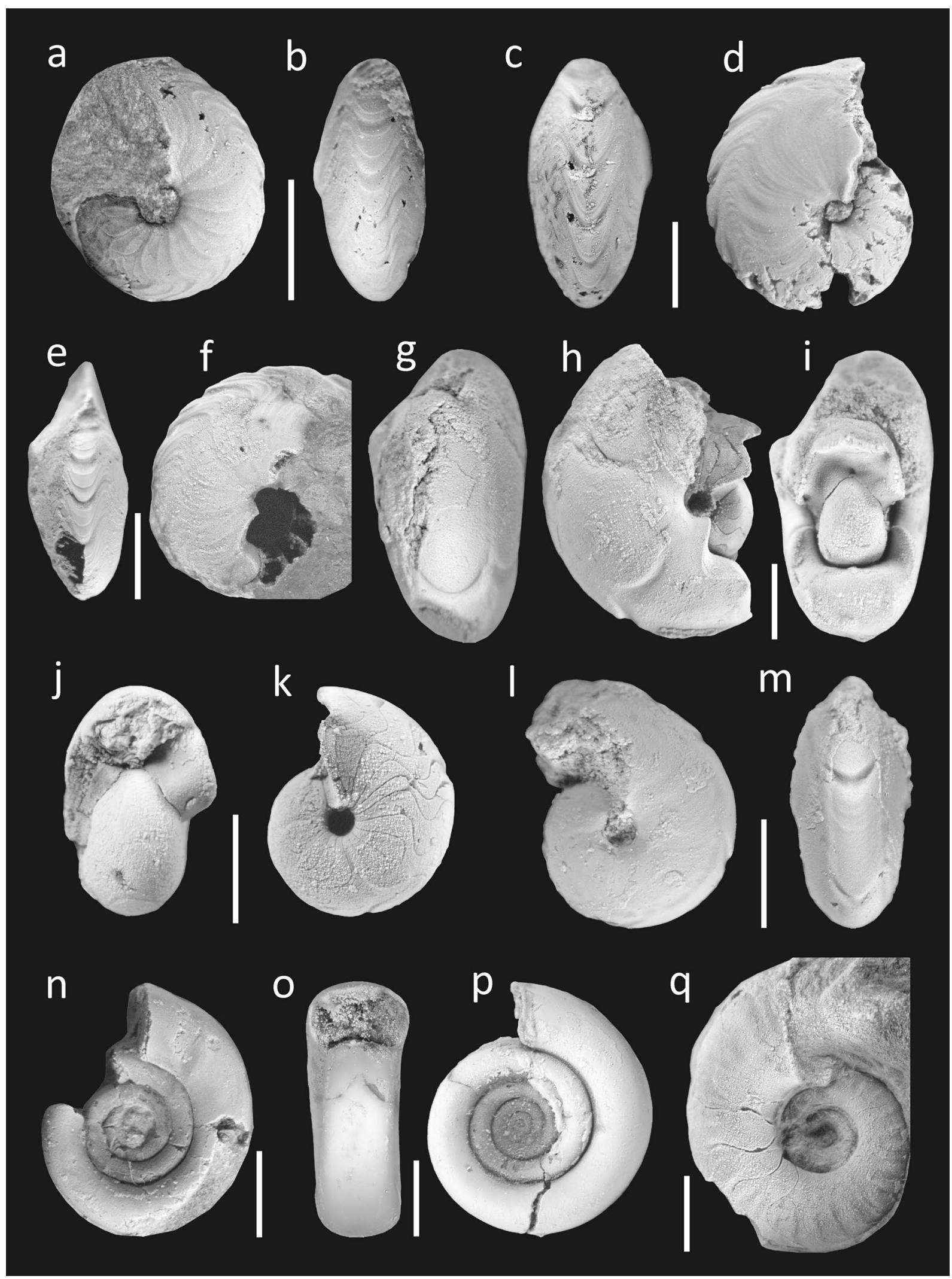


4Fig. 2 Tornoceratidae and Gephuroceratoidea from the upper Frasnian Sand Formation (scale bar $2 \mathrm{~mm}$ ). a, b Aulatornoceras steinhauseni sp. nov., paratype MB.C.29356.4, showing the bundled growth ornament with high ventrolateral projection without a spiral furrow and the ventral band; lateral and ventral views, Sand 1, $\times 11, \mathbf{c}, \mathbf{d}$ Aul. steinhauseni sp. nov., holotype MB.C.29356.1, subadult specimen with typical growth lirae, V-shaped ventral varices, and incipient ventrolateral furrows; ventral and lateral views, Sand 1, ×8, e, f Aul. steinhauseni sp. nov., paratype MB.C.29356.3, showing the typical ornament without ventrolateral furrows; ventral and lateral views, Sand $1, \times 8, \mathbf{g}-\mathbf{i}$ Aul. frenklerae sp. nov., holotype MB.C.29359, showing the typical varices, lateral and inner suture, and the late onset of incipient ventrolateral furrows; ventral, lateral and oral views, Sand A, $\times 7, \mathbf{j}$, k Aul. frenklerae sp. nov., paratype MB.C.29358, juvenile specimen with V-shaped A-lobe and varices, still lacking ventrolateral furrows; oral and lateral views, Sand 4, ×10, I, m Aul. ventrosulcatum sp. nov., holotype MB.C.29360, showing the typical high whorl height, shallow ventrolateral furrows, ventrally restricted varices, and weak ventral band; lateral and ventral views, Dombach-Sander-Straße, $\times 10$, n "Archoceras" varicosum (Drevermann, 1901), MB.C.29345, typical specimen with varices; lateral view, Sand A, $\times 8, \mathbf{o}, \mathbf{p}$ "Arch." cf. varicosum (Drevermann, 1901), MB.C.29344, with characteristic, simple suture but without varices; oral and lateral views, Sand $\mathrm{A}, \times 7, \mathbf{q}$ Clauseniceras sp. 1 , MB.C.29364.1, juvenile of a new species with regular, weak, subconvex lateral ribbing and suture with subsymmetric flank saddle; lateral view, Sand A, $\times 7$

badly usable to compare the biodiversity of different faunas, because the value of $H$ does not differ between a fauna with many species and uneven distribution or less species with a more even distribution.

Therefore, the Pilou's eveness $(J)$ is preferred here and better usable for comparison of different faunas. Generally, $J$ describes the mass of uniform distribution between species in a given sample. It can range between 0 and 1 , where 0 is the maximum uneven distribution and 1 the maximum uniform distribution. It is denoted by $J=H / H_{\max }$. For the Sand goniatite fauna, it ranges between 0.89 (not corrected) and 0.88 (corrected). This is an extraordinarily high value for $J$, proving both a high ammonoid biodiversity and numerical equality of the palaeocommunity. Typically, unequal faunas with a few dominant species and a high number of rare forms are more common.

The Simpson diversity index $(D)$ is given by Simpson (1949):

$$
D=1-\sum_{i=1}^{s} \frac{n_{i}\left(n_{i}-1\right)}{n(n-1)} .
$$

In both approaches (not corrected and corrected), $D$ is around 0.94 . As a measurement of biodiversity, it refers to the probability that two randomly chosen specimens from a given sample do not belong to the same species with $D$ ranging between 0 and 1 . For a given species richness, $D$ increases as equitability increases. With a value of 0.94 , the
Simpson diversity index $(D)$ is exceedingly high and further underlines the high ammonoid biodiversity of the intra-Kellwasser fauna (UD I-K) of the Sand Formation.

There is so far no literature on upper Frasnian ammonoids that provides similar quantitative assemblage data and calculations that could be used for statistical comparisons. Currently, we can only compare simple species counts (alpha diversities) from known localities of the same age (UD I-K), especially, where there is evidence for intensive collecting, partly over many decades:

- Seßacker, Trench II (southern Rhenish Massif, Germany); Matern (1931a): 15 species (5 tornoceratids), Lower Kellwasser Limestone and overlying cephalopod limestones

- Alter Tal (Harz Mountains, Germany); Fuhrmann (1954): 9 species (2 tornoceratids), limestones above the Lower Kellwasser Limestone

- Waterside Cove (Cornwall, U.K.); House (2002): 19 species (9 tornoceratids), goniatite shale

- Coumiac (Montagne Noire, France); Becker and House (1994): 5 or 6 species (2 tornoceratids), Lower Kellwasser Limestone and overlying cephalopod limestones

- Oued Mzerreb (Dra Valley, Morocco); Becker et al. (2004): 2 species (0 tornoceratids), Lower Kellwasser Limestone equivalent

- Płucki (Holy Cross Mountains, Poland); Dzik (2002): 4 species (2 tornoceratids), Lower Kellwasser Limestone equivalent

- Lower Hannover Shale (New York State, USA); Miller (1938), House and Kirchgasser (2008) and new collections: 5 species ( 3 tornoceratids), goniatite shale

- Delphi (Indiana, USA); Miller (1938) and House and Kirchgasser (2008): 3 species (0 tornoceratids), goniatite shale

The much higher total diversity in the Sand Formation may partly reflect a larger sample size than in some of these sections. Furthermore, we use specimens from different collecting spots and not only from one single bed, which can cause an overestimation of the biodiversity. Other aspects such as potential undetected sexual dimorphism, which was, however, never verified for palaeozoic ammonoids, have to be taken into account, but can not be addressed within this study. It is, therefore, necessary to collect more quantitative data from other contemporaneous localities. These can be subject to more detailed statistical treatments, which consider sample size differences relative to variable local assemblage structures. 


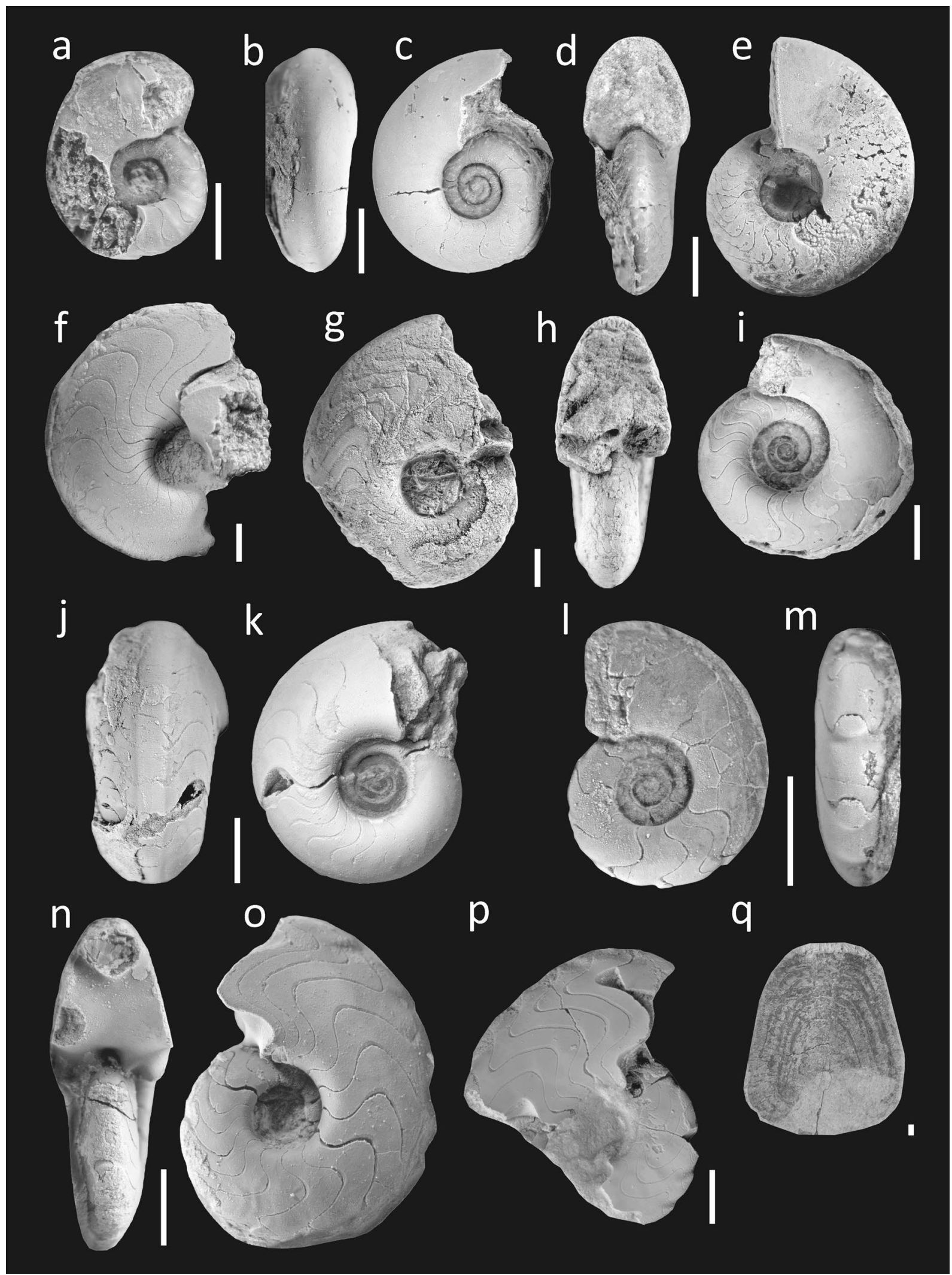


4Fig. 3 Examples of Gephuroceratidae from the upper Frasnian Sand Formation (scale bar $2 \mathrm{~mm}$ ). a Clauseniceras sp. 1, MB.C.29364.2, juvenile specimen showing radial flank ribbing and typical sutures; lateral view, Sand A, ×7, b, c Manticoceras aff. lamed (Sandberger and Sandberger, 1850/51), MB.C.29389, juvenile with visible protoconch and slender cross-section; ventral and lateral views, Sand 4, $\times 6$, d, e $M$. cordatum (Sandberger and Sandberger, 1850/51), MB.C.29391, showing the suture and tegoid whorl form; ventral and lateral views, Sand A, $\times 5.5$, f M. cordatum (G. \& F. Sandberger, 1850/51), MB.C.29390, typical specimen showing the suture with a pronounced dorsolateral saddle; lateral view, Sand $3 \mathrm{~A}, \times 3.5, \mathbf{g}-\mathbf{h} M$. drevermanni Wedekind, 1913, MB.C.29392, with pointed umbilical lobe and triangular flank saddle as typical for the species; lateral and ventral views, Dombach-Sander-Straße, $\times 3.5$, i Sphaeromanticoceras affine (Steininger, 1949), MB.C.29397, juvenile with Ritzstreifung on the mould; lateral view, Sand $3 \mathrm{C}, \times 5, \mathbf{j}, \mathbf{k}$ Sphaero. orbiculum (Beyrich, 1837), MB.C.29398, juvenile with Ritzstreifung and keeled venter as typical for the genus; ventral and lateral, Sand $3, \times 6, \mathbf{l}, \mathbf{m}$ Serramanticoceras serratum (Steininger, 1849), MB.C.29395, small specimen with still rounded venter and characteristic ventral varices; lateral and ventral views, Sand $3 \mathrm{~A}, \times 10$, n, o Serra. serratum (Steininger, 1849), MB.C.29396, with semi-trapezoidal whorl cross section and typical suture; oral and lateral views, Sand 3B, $\times 6$, p Serra. cf. obliquesulcatum (Clausen, 1969), MB.C.29394, with ventral varices extending in the early part of the last whorl onto the flanks; lateral view Sand 3B, $\times 5$, k Anaptychid jaw, specimen Sand3_AnaCH03, squashed, isolated lower jaw with central fractures and concentric, lamellose growth lirae; Sand $3, \times 1$

Interestingly, both the Tornoceratoidea and Gephuroceratoidea independently developed in UD I-K new genera (Retrotornoceras and "Archoceras") with a characteristic, simplified suture. This new feature is possibly an adaptation to ecological changes (high-productivity regime, dysoxic/anoxic conditions) due to the Lower Kellwasser Event. Simple sutures mean a reduced pellicle surface within the chambers and, therefore, probably a less efficient osmotic pump and slow vertical mobility (Mutvei 1967; Klug and Hoffmann 2015). Conveniently, the genus Beloceras, with its complicated, extremely multilobate sutures, is generally rare in hypoxic facies and is actually completely missing in the Sand Formation. However, "Archoceras" (6.6\% in total, $12 \%$ of Sand Gephuroceratoidea) and Retrotornoceras ( $0.4 \%$ in total, $1 \%$ of Sand Tornoceratoidea) represent only minorities in terms of abundance (Fig. 5). Typical for a stratigraphic position above the Lower Kellwasser level is the absence at Sand of members of the Acanthoclymeniidae, oxyconic Virginoceratinae, and of Maternoceratinae (see Becker and House 1993). However, it is remarkable that the Sand fauna apparently lacks Delphiceras, which is a characteristic genus of hypoxic strata of UD I-K in North America, southern Morocco, the Ardennes, SW England, and the Eifel Mountains (Gatley 1983; Becker and House 1993, 2000a; House 2002; new collections).

Another intriguing palaeoecological aspect is the apparent local absence of $P h$. frechi and of any other species of this long-ranging genus. In the upper Frasnian, it was widespread and very common in the black Kellwasser Limestone facies, especially of more shallow, hypoxic, pelagic carbonate platforms (e.g., of southern Morocco), where its streamlined, strongly compressed shell enabled it to cope with currents and storms. Though Ph. frechi was not the only survivor of the Upper Kellwasser Event, it represents the only species blooming enormously directly after the Frasnian-Famennian boundary (Becker 1993a, b). Therefore, it was a typical "disaster taxon" (Fischer and Arthur 1977; Harries et al. 1996). Only after the extinction (gephuroceratids) and disappearance (Aulatornoceratinae and Tornoceratinae) of other ammonoid taxa, it spread opportunistically to the post-crisis (basal Famennian) calm goniatite shale facies, for example of the Montagne Noire (Col du Puech de la Suque, Becker 1993a).

The high alpha diversity of Sand ammonoids and the high amount of new taxa shed new light on the discussion, whether the global Kellwasser Crisis does represent a major mass extinction or just a time of reduced speciation. Our new results indicate a continuing, high speciation rate in tornoceratids with and after the Lower Kellwasser Event

\begin{tabular}{|c|c|c|c|}
\hline Stage & Formation & Ammonoid genozone & Key \\
\hline \multirow{6}{*}{ 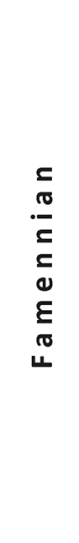 } & \multirow{6}{*}{$\begin{array}{c}\text { Knoppenbissen } \\
\text { Formation } \\
\text { (lower part) }\end{array}$} & & \\
\hline & & Praemeroceras & UD II-E \\
\hline & & Paratorleyoceras & UD II-D \\
\hline & & Cheiloceras & UD II-C \\
\hline & & Compactoceras & UD II-B \\
\hline & & Phoenixites & UD II-A \\
\hline \multirow{7}{*}{\begin{tabular}{l}
$c$ \\
$\pi$ \\
\multicolumn{1}{c}{} \\
$\sim$ \\
$\pi$ \\
$\frac{1}{4}$
\end{tabular}} & Upper & Crickites & UD I-L \\
\hline & Kellwasser Horizon & \multirow{2}{*}{ "Archoceras" } & \multirow[b]{2}{*}{ UD I-K } \\
\hline & Lower & & \\
\hline & \multirow{2}{*}{ Sand Formation } & Neomanticoceras & UD I-J \\
\hline & & Playfordites & UD I-I \\
\hline & Hombach Formation & & \\
\hline & Tonschiefer Formation & Mesobeloceras & UD I-G \\
\hline
\end{tabular}

Fig. 4 Stratigraphy of the Bergisch Gladbach-Paffrath Syncline 
Fig. 5 Bar plots showing the relative ammonoid abundance at genus level. a Relative abundance of Tornoceratoidea genera, b Relative abundance of Gephuroceratoidea genera
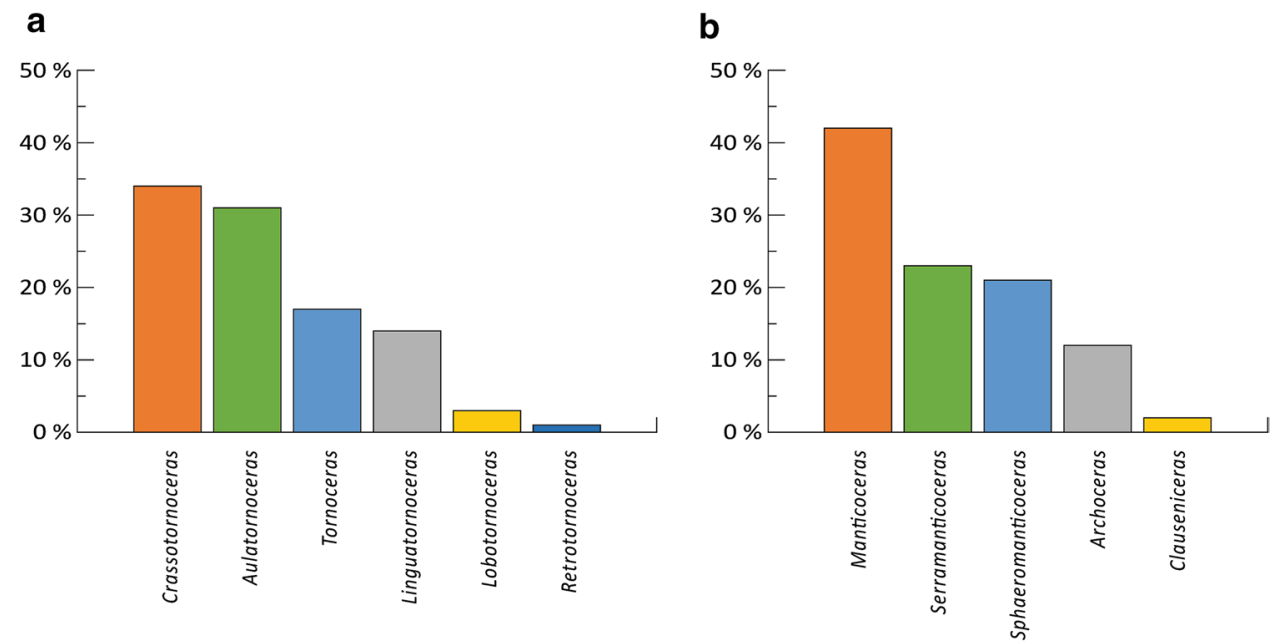

(within UD I-K). This will be further substantiated by comparisons with pre-Kellwasser faunas and with unpublished collections from other regions. The revision of Upper Kellwasser faunas (UD I-L) will eventually provide precision concerning the timing and rates of terminal Frasnian extinctions.

\section{Internal parasitism of ammonoids}

Representative specimens of five genera (Aulatornoceras, Crassotornoceras, Linguatornoceras, Tornoceras and Clauseniceras) of both ammonoid superfamilies display a new type of "Housean Pits" on their steinkerns. "Housean Pits" were first described by House (1960) and denote more or less regularly distributed pits on internal moulds. They occur as a result of internal parasitism (probably by trematodes), which resulted in a subsequent local thickening of the inner shell wall (De Baets et al. 2011). Most occurrences are found in Emsian and Eifelian anarcestid ammonoids, the superfamily which includes the ancestors of both the Tornoceratoidea and Gephuroceratoidea. "Housean Pits" on tornoceratids (Aulatornoceratinae) have so far only been shortly mentioned by De Baets et al. (2015). We present the first observation of "Housean Pits" on gephuroceratid ammonoids (specimen MB.C.29364.3, Pit type 6). A very rare case of "Housean Pits" has been documented in sporadoceratids from the middle Famennian of Poland (Rakocinski 2012). This group derived via the Cheiloceratoidea from tornoceratids (e.g., Becker 1993a). Furthermore, isolated blister pearls are known in Jurassic ammonoids from Germany (Keupp 1986) and blister pearl clusters are known for instance from Silurian nautiloids (Stridsberg and Turek 1997; Manda and Turek 2009; Turek and Manda 2010).

The "Housean Pits" from Bergisch Gladbach-Sand are exclusively circular and occur on the flanks in two ways.
Rarely, they appear as a few pairs (e.g., MB.C.29406.1, Fig. 6g-h), slightly resembling Pit type 4 (Opitzian pits) sensu De Baets et al. (2011) and De Baets et al. (2013). However, in the case of our T. aequilobum sp. nov., the paired pits are neither connected nor were they formed at the aperture. Most of the pits in Bergisch Gladbach-Sand ammonoids are more or less spirally arranged, isolated circular pits on the flanks (e.g., MB.C.29413, Fig. 61-n). We propose a new Pit type 6 extending the nomenclature of De Baets et al. (2011). They differ from Pit type 3 by occurring not only at the end of the body chamber, with more pits per whorl, and from Pit type 2 by being larger, occurring in smaller numbers, and only in a single undulating flank row. At specimen MB.C.29413 (Fig. 61-n) the new Pit type 6 is not formed at the end of the body chamber but at least $170^{\circ}$ away from the last suture. Because it is not clear whether the pits occur at the aperture and since there is no observable effect on shell growth, Type 6 pits are still considered as "Housean Pits" and not as "Opitzian Pits".

The following summary extends the original scheme by De Baets et al. (2011, 2015):

- Pit type 1 (Housean Pits): fairly large oval pits, which are lengthened in a longitudinal direction, predominately ordered in large spiral rows and often paired.

- Pit type 2 (Housean Pits): multiple, small pits, arranged in more or less radial rows or more chaotically.

- Pit type 3 (Housean Pits): rare circular pits with a central deepening.

- Pit type 4 (Opitzian Pits): flat, large, radially arranged, paired pits formed at the front of the body chamber and locally affecting shell growth at the aperture.

- Pit type 5: kidney-shaped pits in the middle of the venter usually at the most posterior points of the hyponomic sinus of their growth lines. Pit type 5 is probably not 
formed due to parasitism (see discussion in De Baets et al. 2015).

- Pit type 6 (Housean Pits, new): multiple, medium-sized pits, arranged in a more or less radial row, and partially formed in the middle of the body chamber without affecting the shell growth at the aperture.

The "Housean Pits" occurring on five different genera of goniatites from the upper Frasnian of Bergisch Gladbach-Sand confirm the discovery of Rakocinski (2012) that ammonoid parasitism was not only a common phenomenon in the Lower and Middle Devonian, but also a recurrent palaeopathological feature in Upper Devonian anarcestid descendents.

\section{Systematics}

The ammonoids were described using the morphological key of Korn (2010). For conch dimensions and morphological terminology see Fig. 7. Concerning the open nomenclature, we follow Bengtson (1988). Although most of the Sand tornoceratids are small in size, the large majority of specimens display all morphological features required for reliable identification and for the introduction of new taxa. Whilst members of the Tornoceratinae may reach moderate size (50-100 mm dm), Crassotornoceras, Aulatornoceras, and Retrotornoceras are very small genera that hardly reach $20 \mathrm{~mm} \mathrm{dm}$, not only in hypoxic goniatite shale facies but also in oxic cephalopod limestones, where environmental conditions should have been optimal.

The Tornoceratidae and all figured Gephuroceratoidea are housed in the Museum für Naturkunde Berlin, with the catalogue numbers MB.C.29344 to MB.C.29413 and MB.C.29434 to MB.C.29435. The remaining Gephuroceratoidea are currently deposited at the Institute of Palaeontology and Geology of the University of Münster. The anaptychids, including the illustrated specimen, are currently stored by $\mathrm{KJH}$.

Institutional abbreviations. WWU-University of Münster, Münster, Germany; OUM-Oxford University Museum, Oxford, UK; MB-Museum für Naturkunde Berlin, Berlin, Germany; SMF-Senckenberg Museum, Frankfurt a.M., Germany; MRHN-Royal Belgian Institute of Natural Sciences, Brussels, Belgium; SedgM-Sedgwick Museum of Earth Sciences, Cambridge, UK; MWNHMuseum Wiesbaden, Wiesbaden, Germany.

Order Goniatitida Hyatt, 1884

Family Tornoceratidae Wedekind, 1910

Subfamily Tornoceratinae Wedekind, 1910

Genus Tornoceras Hyatt, 1884
Tornoceras holwilli (House, 2002), emended

Figures 6a-e, 8a-b, 9a; Tables 1, 2

e.p. 1895 Tornoceras simplex Mut. ovata Münster-Holzapfel: 99-100 [non fig. $6=$ Ling. linguum]

e.p. 1897 Tornoceras simplex —Frech, pl. 32a, fig. 11 [only]

? 1902 Tornoceras simplex mut. ovata-Frech: 47, pl. III, figs. 21a-b

? 1965 Tornoceras (Linguatornoceras) aff. linguum-House: 112-113, fig. 13E, pl. 9, figs. 82-83

v 2000 Tornoceras typum-Becker et al.: 73, 75, 90-92, fig. 7D, pl. 2, figs. 7-8

2002 Linguatornoceras "ovatum" Frech-House: 275, figs. 3D-E

* 2002 Linguatornoceras holwilli-House: 275, fig. 3L, pl. 3, figs. I-J

e.p. 2002 Linguatornoceras sp. -Dzik: figs. 56Q-U [non figs. $54 \mathrm{~N}-\mathrm{S}$, partly $=P h$. frechi $]$

?e.p. 2008 Linguatornoceras aff. linguum-House and Kirchgasser: $167-168$, text-figs. 56A-C, 56E-F (repeated from House 2002), pl. 27, fig. 12, pl. 33, figs. 7-8 [?non text-fig. 56D, pl. 33, figs. 1-2, 5-6]

e.p. 2008 Linguatornoceras linguum-House and Kirchgasser: pl. 27, fig. 14 [non pl. 27, fig. $13=$ L. clausum]

Holotype. OUM D224 (Oxford University Museum, Oxford).

Material. MB.C.29399.1, MB.C.29399.2, MB.C.29399.3, MB.C.29400.1, MB.C.29400.2, MB.C.29401.1, MB.C.29401.2, MB.C.29402, MB.C.29403.1, MB.C.29403.2, MB.C.29403.3.

Type locality. Waterside Cove, South Devon.

Type level. Saltern Cove Goniatite Bed, upper Frasnian, UD $\mathrm{I}-\mathrm{K} / \mathrm{L}$.

Diagnosis (emended). See House (2002: 275), adding as distinctive features a narrow, asymmetrically rounded, deep A-lobe and an arched, moderately wide ventrolateral saddle, which height is $50-80 \%$ of the height of the dorsolateral saddle.

Description. The Sand material contains 11 small, wellpreserved specimens displaying the conch form, sutures, and ornament. Conch shape in intermediate stages thickly discoidal (ww/dm 0.50 at $10 \mathrm{~mm} \mathrm{dm}$ ), with rounded flanks, becoming subsequently thinly discoidal (ww/dm 0.47 just after $10 \mathrm{~mm} \mathrm{dm}$ ) and weakly compressed (ww/wh 0.80-0.95 at $9-12 \mathrm{~mm} \mathrm{dm}$ ). All specimens are involute and the WER is increasing from moderate $(1.75-1.85$ at $3.50 \mathrm{~mm} \mathrm{dm})$ to very high ( 2.50 at $16 \mathrm{~mm} \mathrm{dm})$. Specimen MB.C.29402 is a juvenile of $6.2 \mathrm{~mm} \mathrm{dm}$ with a broad, gently ascending dorsolateral saddle, markedly asymmetric, rounded A-lobe, 

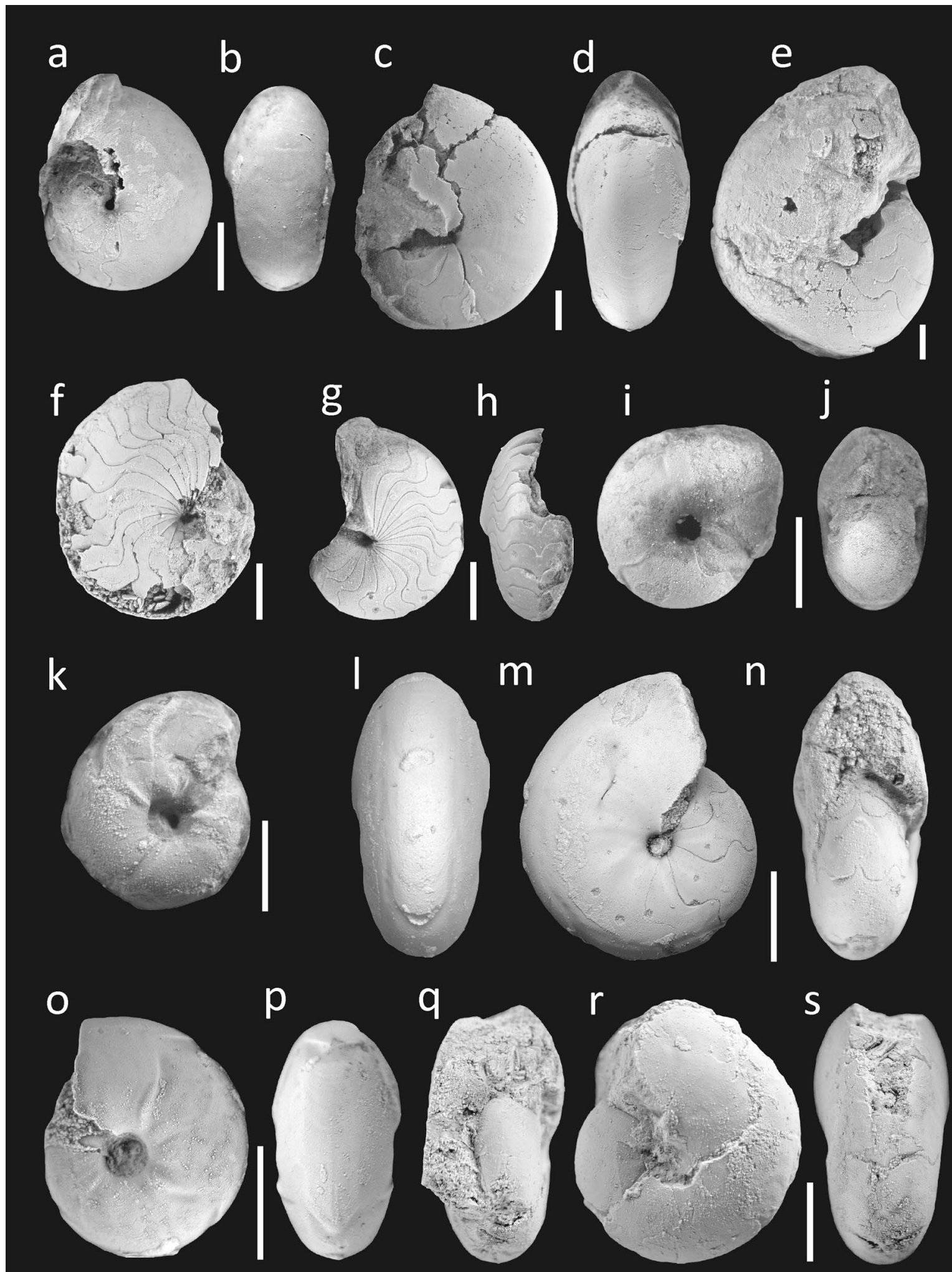
4Fig. 6 Tornoceratinae from the upper Frasnian Sand Formation (scale bar $2 \mathrm{~mm}$ ). a, b Tornoceras holwilli (House, 2002), MB.C.29402, showing the wide ventral sinus of the growth lines and the relatively narrow, slightly asymmetric A-lobe, which is intermediate towards Linguatornoceras; lateral and ventral views, Sand $3 \mathrm{C}, \times 5$, c, d T. holwilli (House, 2002), MB.C.29399.3, showing the smooth rounded flank, and asymmetric A-lobe; lateral and ventral views, Sand 3,×3.5, e T. holwilli (House, 2002), MB.C.29401.1, subadult with narrow, asymmetric A-lobe; lateral view, Sand $3 \mathrm{~B}, \times 3, \mathbf{f} T$. aequilobum sp. nov., paratype MB.C.29406.3, partly squashed specimen with dense septal spacing, showing the wide A-lobe and low ventrolateral saddle; lateral view, Sand A, $\times 5, \mathbf{g}, \mathbf{h}$ T. aequilobum sp. nov., holotype MB.C.29406.1, showing the shallow, symmetric A-lobe of closely spaced septa as well as some irregular "Housean Pits"; lateral and ventral views, Sand A, $\times 5, \mathbf{i}, \mathbf{j}$ Crassotornoceras crassum (Matern, 1931a), MB.C.29370, juvenile with pachyconic conch displaying weak varices and a typical suture with a low ventrolateral saddle; lateral and oral views, Sand $3 \mathrm{~B}, \times 8, \mathbf{k} \mathrm{Cr}$. crassum (Matern, 1931a), MB.C.29372.2, displaying marked, concavo-convex varices, slightly intermediate towards $\mathrm{Cr}$. belgicum due to a rib associated with the last varix; lateral view, Sand A, $\times 8, \mathbf{l}-\mathbf{n} C r$. aff. belgicum (Matern, 1931b), MB.C.29413, displaying weak lateral ribbing, ventral varices, incipient ventrolateral furrows, Crassotornocerastype sutures, and "Housean Pits"; lateral and ventral views, Sand A, $\times 8$, o, p Cr. belgicum (Matern, 1931b), MB.C.29365.1, with typical varices and associated lateral ribbing; lateral and ventral views, Dombach-Sander-Straße, $\times 10, \mathbf{q}-\mathbf{s}$ Cr. nudum sp. nov., holotype MB.C.29373.1, with a typical Crassotornoceras-type suture but lacking varices or ribbing; ventral, lateral and ventral views, Sand $\mathrm{A}, \times 7$

and strongly asymmetric ventrolateral saddle (Fig. 8b). It possesses a closed umbilicus (uw/dm 0.05), short and well-rounded umbilical wall, and gently rounded flanks (Fig. 6a-b). Growth lines of MB.C.29399.3 (at $4.6 \mathrm{~mm}$ wh) are characterized by a low dorsolateral projection, wide, ascending lateral sinus, marked, narrow ventrolateral projection, and a wide, moderately deep, rounded ventral sinus (Fig. 9a). A larger specimen (MB.C.29401.1, $16 \mathrm{~mm} \mathrm{dm}$ ) displays an asymmetrically rounded A-lobe and broad ventrolateral saddle that is slightly lower than the dorsolateral saddle (Figs. 6e, 8a). Specimen MB.C.29401.2 differs by a slightly wider A-lobe. Impressions of the fine biconvex growth lines with a wide ventral sinus are also preserved in MB.C.29399.3 (Fig. 6d). The cross-section is tegoid, with rounded flanks.

Remarks. In the early literature on Devonian ammonoids, our form would have been listed as T. simplex (Buch, 1832), which, however, was originally shown to possess a markedly open umbilicus (for discussion see House 1965: 112, and Becker 1993a). The age of this form, currently a nom. dub., is unclear; it could well represent an Eifelian taxon. Holzapfel (1895) recognized several T. simplex variants ("mutants"), whose names are available as subspecies or species. Specimens with a variably narrow A-lobe and arched ventrolateral saddle were included in his "Mut. ovata Münster". The latter name refers to the much larger Famennian G. ovatus Münster, 1832, another nom. dub. of unresolved taxonomic affinities (for discussion see Becker 1993a: 277). Reading Holzapfel's (1895) description, it becomes clear that he combined under the same name a range of very different tornoceratids, including Linguatornoceras species.

Frech (1902) followed Holzapfel's taxonomic concept and applied it to Büdesheim Tornoceras. But he illustrated under the name "Tornoceras simplex mut. ovata" a suture with an unusually small and narrow ventrolateral saddle that is not typical for the most common Büdesheim form. When House (1965) introduced the subgenus Linguatornoceras, he included the common Büdesheim species and similar North American specimens as T. (Ling.) aff. linguum. The latter is intermediate between Tornoceras and Linguatornoceras and we restrict Linguatornoceras to species with an at least subparallel-sided A-lobe.

House $(1963,1965,2002)$ emphasized that the Büdesheim form occurs also at Waterside Cove in South Devon. He assigned a few specimens characterized by incomplete preservation of the E-lobe, probably caused by an episodic siphuncle shift, to a new species, Ling. holwilli. In all other aspects, it is identical with his Ling. aff. linguum or Ling. "ovatum" Frech. Since we are not convinced about the taxonomic significance of the episodically incomplete E-lobe, holwilli seems to be the available name for the common Tornoceras species of Sand. Specimens with narrower and smaller ventrolateral saddle (Frech 1902; House 1965; House and Kirchgasser 2008) are assigned with an uncertainty: these could represent intraspecific variants. We exclude specimens with a much lower ventrolateral saddle ( $<50 \%$ of height of dorsolateral saddle; e.g., T. cf. typum in Becker and House 1994; House and Kirchgasser 2008). They are intermediate towards T. contractum Glenister, 1958.

Tornoceras holwilli is closely related to T. typum (Sandberger and Sandberger, 1851), which differs in the mature flattening of its converging flanks, lower WER (ca. 2.00), a high relief of the suture, and a less arched ventrolateral saddle. Despite many references in the literature, including old quotations of "T. simplex", T. typum is poorly known apart from its lectotype from Oberscheld (Rhenish Massif). A revision based on the morphometry of topotypes will have to specify the holwilli-typum relationships. The Givetian/ Frasnian North American T. uniangulare-T. iowaense Group differs from $T$. holwilli in their narrower ventrolateral saddle with an obliquely ascending lateral pronge. Rhenish upper Givetian Tornoceras, including T. wunderlichi Bockwinkel and Korn (2015), belong to the T. contractum Group with a low ventrolateral saddle (see Bockwinkel et al. 2013 and Bockwinkel and Korn 2017). The top-lower Frasnian Domanikoceras timidum Becker and House in Becker et al. (2000) is thicker and lacks a lateral sinus of the growth lines. 
Stratigraphic range. Lower Frasnian of the Timan (Becker et al. 2000, upper UD I-D) to the upper Frasnian of South Devon (House 2002, UD I-K/L).

\section{Tornoceras aequilobum sp. nov.}

Figures $6 \mathrm{f}-\mathrm{h}, 8 \mathrm{c}-\mathrm{d}$; Tables 1, 2

Etymology. Named after the subsymmetrically rounded A-lobe.

Holotype. MB.C.29406.1 (Museum für Naturkunde Berlin).

Paratypes. MB.C.29404.1, MB.C.29404.2, MB.C.29405, MB.C.29406.2, and MB.C.29406.3.

Type locality. Loc. Sand A, construction site at the Herkenrather Straße 70 of Bergisch Gladbach-Sand.

Type level. Sand Formation, upper Frasnian, UD I-K.

Diagnosis. Conch thinly discoidal (ww/dm $0.45-0.55$ at 6-8 $\mathrm{mm} \mathrm{dm}$ ), weakly compressed (ww/wh $0.80-0.95$ at 6-8 $\mathrm{mm} \mathrm{dm}$ ), with slightly flattened flanks and high to very high whorl expansion rate (WER ca. 2.40-2.50). Conch always involute (uw/dm 0.05) and smooth. Suture with a wide, asymmetric and low dorsolateral saddle, moderately shallow, subsymmetric, widely rounded A-lobe, low, asymmetrically rounded ventrolateral saddle with almost the same height as the dorsolateral saddle, and small, very narrow, short E-lobe; septal spacing characteristically dense (ca. 20 sutures per whorl).

Description. The Sand specimens range in size between 3.5 to $8.4 \mathrm{~mm} \mathrm{dm}$. Holotype MB.C.29406.1 is still attached to its rock matrix and is a late juvenile with $6.6 \mathrm{~mm} \mathrm{dm}$, but it is the best-preserved specimen. It displays dense septal spacing, the typical, broad, subsymmetric, rounded A-lobe, a thinly discoidal involute conch (ww/dm 0.45 , uw/dm 0.05 ), and a moderately wide, gently rounded venter. The umbilical wall is rounded in the partially crushed paratype MB.C.29406.3. The internal suture and the growth lines are not preserved. There are no furrows or ribbing. All specimens have dense septal spacing in common (e.g., Fig. 6f-h). In the juvenile paratype MB.C.29404.1, it is already developed at $3.5 \mathrm{~mm} \mathrm{dm}$.

Remarks. The species differs from most other named Tornoceras species by the wide, almost symmetrically rounded A-lobe, low relief of suture, and dense septal crowding. The septal crowding being already developed on juveniles is ruling out maturity as a potential reason. While it is observed on each specimen of T. aequilobum sp. nov., it has to be considered that ecological stress can support dense septal crowding. Holzapfel (1895) identified lower/middle Frasnian specimens from many different localities with a subsymmetric saddle and A-lobe, but with higher relief of the suture, as "T. simplex Mut. angustelobata". Only a suture was illustrated. In the absence of any figured type-material, this taxon is currently a nom. dub. More material of T. aequilobum sp. nov. is available from Büdesheim (Eifel) and Boudouda (Morrocan Meseta).

Stratigraphic range. Currently restricted to the upper Frasnian (UD I-I/J to UD I-K).

Genus Crassotornoceras House and Price, 1985

Crassotornoceras crassum (Matern, 1931a), emended Figures 6i-k, 8e, 9b; Tables 1, 2, 3, 4

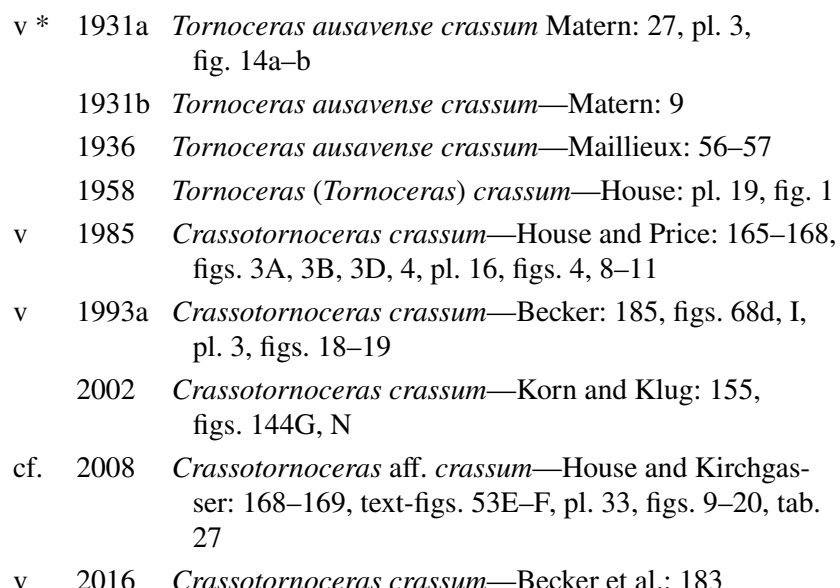

Holotype. SMF XI 342a (Senckenberg Museum, Frankfurt a.M.).

Material. MB.C.29369, MB.C.29370, MB.C.29371.1, MB.C.29371.2, MB.C.29372.1, MB.C.29372.2, MB.C.29372.3, MB.C.29372.4, MB.C.29372.5, MB.C.29372.6, MB.C.29372.7, MB.C.29372.8.

Type locality. Büdesheim, Eifel.

Type level. Büdesheim Goniatite Shale, upper Frasnian, UD $\mathrm{I}-\mathrm{I} / \mathrm{J}$.

Diagnosis (emended). Very small-sized; earliest postembryonic stages until ca. $3 \mathrm{~mm}$ dm cadiconic, moderately depressed (ww/wh ca. 1.50 at $2.5 \mathrm{~mm} \mathrm{dm}$ ), with open umbilicus (uw/dm ca. 0.25 at $2.5 \mathrm{~mm} \mathrm{dm}$ ) and moderate WER (1.75 at $2.5 \mathrm{~mm} \mathrm{dm}$ ); at ca. $7 \mathrm{~mm}$ thickly discoidal (ww/ $\mathrm{dm}$ slightly decreasing to 0.50 ), weakly depressed (ww/wh down to 1.10 ), subinvolute (uw/dm 0.15 ), and with slightly 
increasing WER (ca. 1.80); with 3-5 prominent, biconvex varices per whorl, which follow the undulose, strongly biconvex growth lines characterized by a low dorsolateral salient, widely rounded, asymmetric lateral sinus, high ventrolateral projection, and broadly rounded ventral sinus. Suture with an asymmetrically arched, wide dorsolateral saddle, small, narrowly rounded A-lobe, ventrolateral saddle that is much lower than the dorsolateral saddle, and small, narrow, short E-lobe.

Description. Conch diameters of the Sand specimens range between $3 \mathrm{~mm}$ (MB.C.29371.2) and $6.5 \mathrm{~mm}$ (MB.C.29372.3). The material is relatively consistent in its morphology, which suggests small intraspecific variability. Specimen MB.C.29370 is a representative juvenile $(3.95 \mathrm{~mm} \mathrm{dm})$ that displays regular, strongly biconvex varices with a high ventrolateral projection, an open umbilicus (uw/dm 0.16), and a thinly pachyconic (ww/dm 0.61 ), weakly depressed (ww/wh 1.28) conch form with the narrowly rounded umbilical wall, smoothly rounded flanks and venter (Fig. 6i-j). It displays the typical suture with a wide dorsolateral saddle and small A-lobe (Figs. 6i, 8e). The body chamber is at least $350^{\circ}$ long, occupying originally a complete whorl. Rather undulose biconvex growth lines can be observed near the aperture in specimen MB.C.29372.2 (Fig. 9b). They follow in general the course of the varices (Fig. 6k), with a very low dorsolateral projection, widely rounded, ascending lateral sinus, a very high, subtriangular ventrolateral projection, and wide ventral sinus.

Remarks. Crasstornoceras crassum is one of just a few ammonoid species, which survived the Kellwasser Crisis. Lower Famennian specimens (Be1061 and Be703 sensu Becker 1993a) from the eastern Rhenish Massif are identical in terms of conch morphology, suture and growth lines compared to upper Frasnian material. The species is easy to distinguish from associated $\mathrm{Cr}$. belgicum by the lack of flank ribs. The contemporaneous $C r$. anissi House and Price, 1985 from South Devon differs by its higher number of varices, which have a low ventrolateral projection. Specimens from the Point Breeze Goniatite Bed of the Angola Shale of New York (UD I-I/J) identified by House and Kirchgasser (2008) as $C r$. aff. crassum also develop a higher number of varices per whorl during ontogeny, but with a very prominent, strong ventrolateral projection.

Stratigraphic range. Ranges from the upper Frasnian (UD I-J) to the lower Famennian (UD II-C).

Crassotornoceras belgicum (Matern, 1931b), emended Figures 6o-p, 8g, 9c; Tables 1, 2, 4, 5
* 1931b Tornoceras belgicum Matern: 9-11, fig. 2

1936 Tornoceras belgicum-Maillieux: 57, fig. 2

aff. 1958 Tornoceras (?Aulatornoceras) aff. belgicum-House: 190-191, pl. 21, figs. 6, 7, 11

v 1985 Crassotornoceras belgicum-House and Price: 169, text-fig. 3C, pl. 16, figs. 1-3 [re-illustration of holotype]

2002 Crassotornoceras belgicum - Korn and Klug: 155

non 2002 Aulatornoceras belgicum-Dzik: figs. 52B-C, 53P-R, $54 \mathrm{I}-\mathrm{M}, 56 \mathrm{~N}-\mathrm{P}[=$ Aul. cf. constrictum $]$

Holotype. MRHN, unnumbered (Royal Belgian Institute of Natural Sciences, Brussels).

Material. MB.C.29365.1, MB.C.29365.2, MB.C.29366, MB.C.29367, MB.C.29368.1, MB.C.29368.2, MB.C.29368.3, MB.C.29368.4, MB.C.29368.5.

Type locality. Quarry behind the church at Boussu en Fagne, Belgium.

Type level. Upper Matagne Shale (F3b), upper Frasnian, UD I-L.

Diagnosis (emended). Very small-sized; conch wellrounded, changing from thinly pachyconic (ww/dm 0.65), weakly depressed (ww/wh ca. 1.20), with moderate to high WER (1.90-2.05), and open umbilicus (uw/dm 0.15) at 3-4 mm dm to thickly discoidal (ww/dm 0.45), weakly compressed (ww/wh 0.90-1.00), with high WER (2.00-2.10) and narrow umbilicus (uw/dm 0.10) at $6.5 \mathrm{~mm} \mathrm{dm}$; per whorl with 3-4, widely-spaced, strongly biconvex varices and around six parallel, prominent ribs on the flank. Suture with wide, asymmetric highly arched dorsolateral saddle, small, narrowly rounded, slightly asymmetric A-lobe, small, low, rounded ventrolateral saddle, and small, short E-lobe.

Description. The Sand material demonstrates that the conch shape is shifting during ontogeny from thinly pachyconic (ww/dm 0.64 in MB.C.29368.2) in juveniles to thickly discoidal (ww/dm <0.60). MB.C.29365.1 $(4.3 \mathrm{~mm} \mathrm{dm}$, Fig. 6o-p) resembles the Belgium holotype with respect to conch size, the small, open umbilicus (uw/dm 0.16) with short, rounded wall, ribbing on the flanks, and the strictly biconvex varices. However, it is slightly thinner and the ribs do not reach the ventrolateral projection. Around $270^{\circ}$ of the body chamber is preserved. Growth lines show a very low dorsolateral salient, wide, ascending lateral sinus, a very narrow, strong ventrolateral projection, and a wide, moderately deep ventral sinus (Fig. 9c). Even juvenile specimens of only $3.2 \mathrm{~mm} \mathrm{dm}$, such as MB.C.29368.2, display the typical sutures and regular ribs. MB.C.29365.1 displays 

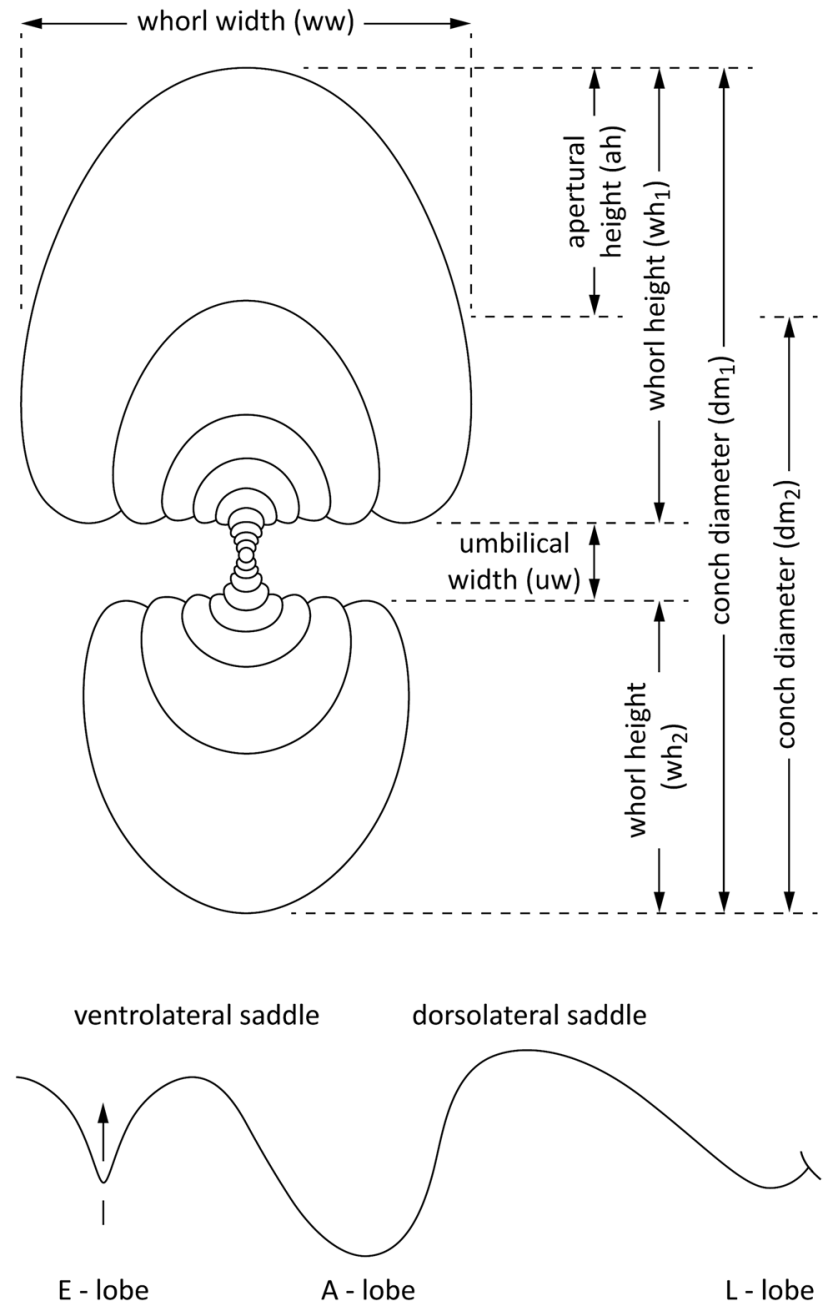

Fig. 7 Measured conch dimensions applying the morphological key of Korn (2010) and terminology of a typical tornoceratid suture

the suture with an arched dorsolateral saddle, small rounded A-lobe, and a ventrolateral saddle that is much lower than the dorsolateral saddle (Fig. 8g).

Remarks. The species is easy to distinguish from all other crassotornoceratids due to its prominent ribs.

Stratigraphic range. Restricted to the upper Frasnian (UD $\mathrm{I}-\mathrm{K} / \mathrm{L})$.

Crassotornoceras aff. belgicum (Matern, 1931b)

Figures 61-n, 8f; Tables 1, 2, 4

Material. MB.C.29413.

Description. Specimen MB.C.29413 has an ovoid, thinly discoidal conch shape (ww/dm 0.45 at $6.3 \mathrm{~mm} \mathrm{dm}$ ) with a very narrow umbilicus (uw/dm 0.07), fast-expanding whorls (WER 2.38), widely-spaced, deeply rounded ventral varices (Fig. 61, n), and seven weak, straight ribs on the inner flanks (Fig. $5 \mathrm{~m}$ ). There is a faint ventrolateral furrow. It also displays more or less regularly distributed "Housean Pits" (Pit type 6, Fig. 6m). The suture possesses a highly arched, asymmetrically rounded dorsolateral saddle, an asymmetric, narrowly rounded A-lobe, and a small, low ventrolateral saddle (Fig. 8f).

Remarks. This currently unique specimen differs from $\mathrm{Cr}$. belgicum in its more compressed conch, the absence of lateral varices, and the presence of an incipient ventrolateral furrow, which is normally typical for Aulatornoceras. For example, Aul. ventrosulcatum sp. nov. (see below) lacks ribs on the flanks, is wider umbilicate, and displays a weak ventral band, as typical for the genus. Since the latter is absent in MB.C.29413, it conforms neither with Aulatornoceras, nor with typical Crassotornoceras. Because we have only one specimen, we place it in open nomenclature until further material becomes available.

Stratigraphic range. Restricted to the upper Frasnian (UD $\mathrm{I}-\mathrm{K})$.

Crassotornoceras nudum sp. nov.

Figures 6q-s, 8h, 10; Tables 1, 2, 4

Etymology. From the latin nudus = naked, due to the lack of any ornamentation on flanks and venter.

Holotype. MB.C.29373.1 (Museum für Naturkunde Berlin).

Paratypes. MB.C.29374, MB.C.29373.2, MB.C.29373.3.

Type locality. Sand A, construction site at the Herkenrather Straße 70 of Bergisch Gladbach-Sand.

Type level. Sand Formation, upper Frasnian, UD I-K.

Diagnosis. Very small-sized; conch at 5.0 to $6.5 \mathrm{~mm} \mathrm{dm}$ thickly discoidal (ww/dm 0.47-0.49), weakly compressed (ww/wh 0.90-1.00), involute (uw/dm 0.10-0.15), with high whorl expansion rate (WER 2.00-2.10), and well-rounded venter; no varices. Suture with an arched, wide dorsolateral saddle, narrow, subsymmetric A-lobe, ventrolateral saddle that is markedly lower than the dorsolateral saddle, and a small, short, divergent, pointed E-lobe.

Description. The holotype has a conch diameter of $6.45 \mathrm{~mm}$ and preserves a short part of the body chamber $\left(\mathrm{ca} .50^{\circ}\right)$. Its flanks and venter are smoothly rounded (Fig. 6s). Despite some incrustation (Fig. 6r), it is clear that the umbilicus is small and open. There is a typical crassotornoceratid-type 
a

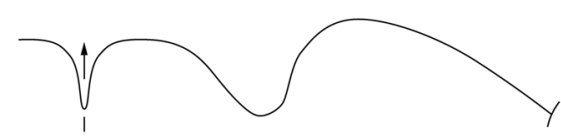

b

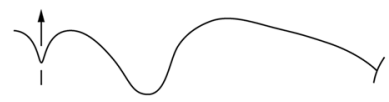

C

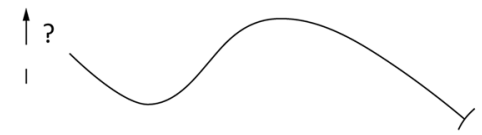

d

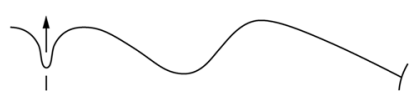

e

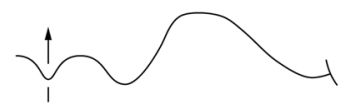

$\mathbf{f}$

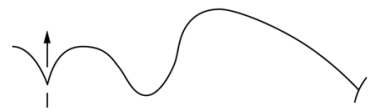

g

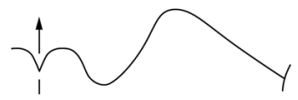

h

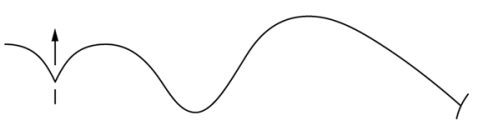

i

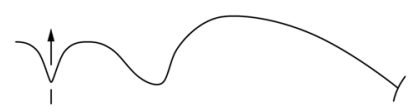

j

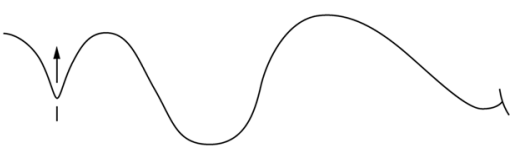

$\mathbf{k}$

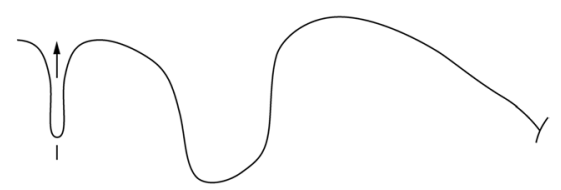

I

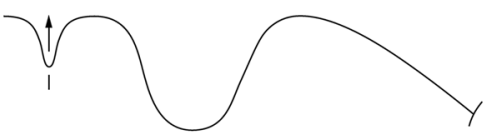

m

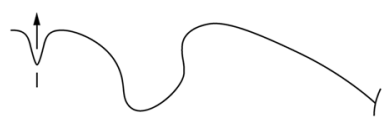

n

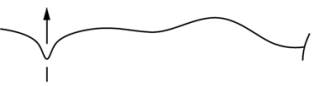

Sander-Straße, at $1.15 \mathrm{~mm}$ wh, h Cr. nudum sp. nov., holotype MB.C.29373.1, Sand A, at $2.86 \mathrm{~mm}$ wh, i Cr. hetzeneggeri sp. nov., holotype MB.C.29375, Sand 3, at $2.25 \mathrm{~mm}$ wh, j Lobotornoceras ausavense (Steininger, 1849), MB.C.29388.1, Sand 3, at $3.50 \mathrm{~mm}$ wh, k Linguatornoceras cf. clausum (Glenister, 1958), MB.C.29381, Sand 3, at $9.20 \mathrm{~mm}$ wh, 1 Ling. linguum (Sandberger and Sandberger, 1850/51), MB.C.29386.2, Sand A, at $3.50 \mathrm{~mm}$ wh, m Ling. sp. 1, MB.C.29387, Sand A, at $2.25 \mathrm{~mm}$ wh, n Retrotornoceras juxi sp. nov., holotype MB.C.29393, Sand 4, at $1.30 \mathrm{~mm}$ wh

and is more rotund, with higher whorl widths (Fig. 10). More material of Cr. nudum sp. nov. is available from Büdesheim (Eifel).

Stratigraphic range. Currently restricted to the upper Frasnian (UD I-I/J to UD I-K).

Crassotornoceras hetzeneggeri sp. nov.

Figures 8i, 9d, 10, 11a-b; Tables 1, 2, 4

Etymology. Named after the owner of the local supermarket, Markus Hetzenegger (Bergisch Gladbach), who was always very supportive for the fossil collecting.

Holotype. MB.C.29375 (Museum für Naturkunde Berlin). Crassotornoceras hetzeneggeri sp. nov. displays weak ribs, 
a

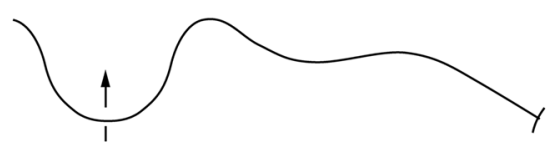

b

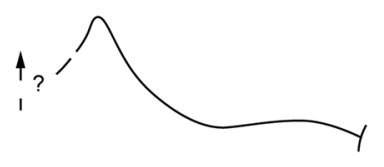

C

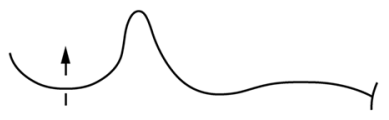

d

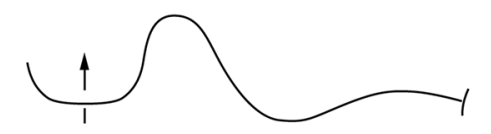

e

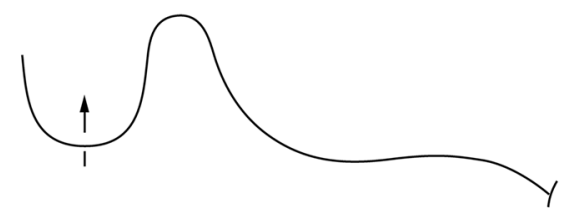

f

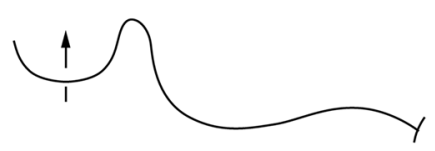

g

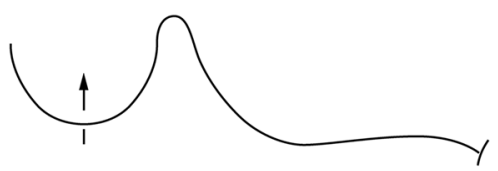

h

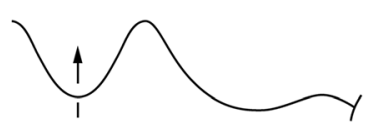

i

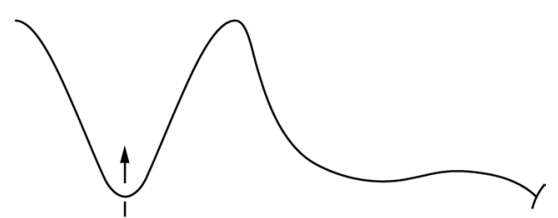

j

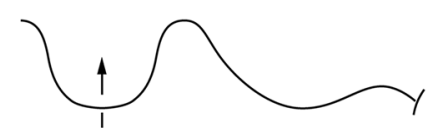

Fig. 9 Growth lines of Tornoceratidae from Bergisch GladbachSand. a Tornoceras holwilli (House, 2002), MB.C.29399.3, Sand 3, at $4.60 \mathrm{~mm}$ wh, b Crassotornoceras crassum (Matern, 1931a), MB.C.29372.2, Sand A, at $2.30 \mathrm{~mm}$ wh, c Cr. belgicum (Matern, 1931b), MB.C.29365.1, Dombach-Sander-Straße at $1.90 \mathrm{~mm}$ wh, d Cr. hetzeneggeri sp. nov., holotype MB.C.29375, Sand 3, at $3.20 \mathrm{~mm}$ wh, e Aulatornoceras auris (Quenstedt, 1846), MB.C.29346.5,

Paratypes. MB.C.29434.1, MB.C.29434.2, MB.C.29434.3.

Type locality. Sand 3, construction site at the Herkenrather Straße 70 of Bergisch Gladbach-Sand.

Type level. Sand Formation, upper Frasnian, UD I-K.

Diagnosis. Very small-sized; conch at $6 \mathrm{~mm}$ dm thinly pachyconic (ww/dm ca. 0.60), weakly depressed (ww/wh 1.051.35 ), involute (uw/dm 0.08), with high whorl expansion rate (WER 2.00-2.10); faint, undulose ribbing near the umbilicus, no varices, growth lines biconvex, with a tongue-shaped, high ventrolateral projection, and deep, wide ventral sinus. Suture with a wide, arched, moderately high, asymmetric dorsolateral saddle, a narrow, small, asymmetrically rounded A-lobe, small ventrolateral saddle that is much lower than the dorsolateral saddle, and narrowly V-shaped, short E-lobe.

Description. The holotype shows a well-rounded, thickly discoidal conch shape at $6.45 \mathrm{~mm} \mathrm{dm}$. The umbilicus is small but open (uw/dm 0.08), with a short, steeply rounded umbilical margin. The flanks are slightly converging towards
Sand 1, at $6.50 \mathrm{~mm}$ wh, f Aul. constrictum (Steininger, 1849), MB.C.29349.1, Sand A, at $3.20 \mathrm{~mm}$ wh, g Aul. eifliense (Steininger, 1849), MB.C.29353.1, Sand A, at $2.90 \mathrm{~mm}$ wh, h Aul. aff. ventrosulcatum, specimen MB.C.29354, Sand 1, at $1.40 \mathrm{~mm}$ wh, i Aul. steinhauseni sp. nov., holotype MB.C.29356.1, Sand 1, at $3.15 \mathrm{~mm}$ wh, j Aul. ventrosulcatum sp. nov., holotype MB.C.29360, DombachSander-Straße, at $2.00 \mathrm{~mm}$ wh

the rounded venter (Fig. 11b), lacking any edges or spiral furrows. There are very weak, undulose ribs on the inner flanks (Fig. 11a). The strongly biconvex, undulose growth lines possess a very low dorsolateral salient, a moderately wide sinus on the flanks, a high ventrolateral projection, and a moderately deep ventral sinus (Fig. 9d). The suture is typical for Crassotornoceras, with a very broad, asymmetrically arched but not very high dorsolateral saddle, small, asymmetric A-lobe characterized by a steeper lateral than ventral limb, and a short, slightly asymmetric ventrolateral saddle that reaches more than $50 \%$ of the height of the dorsolateral saddle. The inner suture is not accessible.

Remarks. The new species differs from Cr. nudum sp. nov. in its more rotund, thicker conch form at comparable size, weak ribs, and lower WER in juveniles (Fig. 10). All other crassotornoceratids possess varices on the inner moulds. Apart from its closed umbilicus, $T$. holwilli differs at the same size in a slightly higher dorsolateral saddle and a lower ventrolateral projection of the growth lines. More material of Cr. hetzeneggeri sp. nov. is available from Büdesheim (Eifel). 
Table 2 Conch dimensions of Bergisch Gladbach-Sand Tornoceratinae [in mm]

\begin{tabular}{|c|c|c|c|c|c|c|c|c|c|c|}
\hline specimen & $\mathrm{dm}$ & wh & ah & ww & uw & ww/wh & $\mathrm{uw} / \mathrm{dm}$ & $\mathrm{ww} / \mathrm{dm}$ & WER & IZR \\
\hline \multicolumn{11}{|c|}{ Tornoceras holwilli (House, 2002) from the Sand Formation } \\
\hline MB.C.29404.1 & 3.28 & 1.70 & 0.85 & - & 0.40 & - & 0.12 & - & 1.82 & 0.50 \\
\hline MB.C.29402 & 6.20 & 3.52 & - & 3.12 & 0.28 & 0.89 & 0.05 & 0.50 & - & - \\
\hline MB.C.29403.1 & 8.70 & 4.85 & - & 4.10 & - & 0.85 & - & 0.47 & - & - \\
\hline MB.C.29403.3 & 9.30 & 5.20 & - & 4.35 & 0.50 & 0.84 & 0.05 & 0.47 & - & - \\
\hline MB.C.29399.3 & 12.00 & 6.50 & - & 5.90 & 0.50 & 0.91 & 0.04 & 0.49 & - & - \\
\hline MB.C.29401.1 & 16.00 & 9.00 & 5.90 & - & - & - & - & - & 2.51 & 0.34 \\
\hline \multicolumn{11}{|c|}{ Tornoceras aequilobum sp. nov. from the Sand Formation } \\
\hline MB.C.29406.1 & 6.60 & 3.66 & - & 3.00 & 0.30 & 0.82 & 0.05 & 0.45 & - & - \\
\hline MB.C.29405 & 7.87 & 4.50 & - & 4.05 & 0.30 & 0.90 & 0.04 & 0.51 & - & - \\
\hline MB.C.29406.3 & 8.40 & 4.80 & - & - & 0.35 & - & 0.04 & - & - & - \\
\hline \multicolumn{11}{|c|}{ Crassotornoceras crassum (Matern, 1931b) from the Sand Formation } \\
\hline MB.C.29370 & 3.95 & 1.87 & - & 2.40 & 0.65 & 1.28 & 0.16 & 0.61 & - & - \\
\hline MB.C.29369 & 4.10 & 2.14 & - & 2.45 & 0.65 & 1.14 & 0.16 & 0.60 & - & - \\
\hline MB.C.29372.3 & 6.56 & - & 1.60 & 3.05 & 1.00 & - & 0.15 & 0.46 & 1.75 & - \\
\hline \multicolumn{11}{|c|}{ Crassotornoceras belgicum (Matern, 1931a) from the Sand Formation } \\
\hline MB.C.29368.2 & 3.19 & 1.73 & - & 2.05 & 0.41 & 1.18 & 0.13 & 0.64 & - & - \\
\hline MB.C.29368.4 & 3.59 & 1.70 & 1.00 & 2.08 & 0.35 & 1.22 & 0.10 & 0.58 & 1.92 & 0.26 \\
\hline MB.C.29365.2 & 3.75 & 1.85 & 1.10 & 2.20 & 0.60 & 1.19 & 0.16 & 0.59 & 2.00 & 0.30 \\
\hline MB.C.29368.5 & 3.80 & 1.95 & 1.15 & 2.25 & 0.60 & 1.15 & 0.16 & 0.59 & 2.06 & 0.31 \\
\hline MB.C.29365.1 & 4.30 & 2.06 & 1.25 & 2.27 & 0.70 & 1.10 & 0.16 & 0.53 & 1.99 & 0.39 \\
\hline MB.C.29368.3 & 4.52 & 2.35 & 1.40 & 2.75 & 0.40 & 1.17 & 0.09 & 0.61 & 2.10 & 0.40 \\
\hline MB.C.29368.1 & 6.46 & 3.18 & 1.95 & - & 0.58 & - & 0.09 & - & 2.05 & 0.39 \\
\hline \multicolumn{11}{|c|}{ Crassotornoceras aff. belgicum (Matern, 1931a) from the Sand Formation } \\
\hline MB.C.29413 & 6.30 & 3.45 & 2.22 & 2.83 & 0.44 & 0.82 & 0.07 & 0.45 & 2.38 & 0.36 \\
\hline \multicolumn{11}{|c|}{ Crassotornoceras nudum sp. nov. from the Sand Formation } \\
\hline MB.C.29373.2 & 4.87 & 2.32 & - & 2.41 & 0.65 & 1.04 & 0.13 & 0.49 & - & - \\
\hline MB.C.29373.1 & 6.45 & 3.10 & 2.00 & 3.00 & 0.90 & 0.97 & 0.14 & 0.47 & 2.10 & 0.31 \\
\hline \multicolumn{11}{|c|}{ Crassotornoceras hetzeneggeri sp. nov. from the Sand Formation } \\
\hline MB.C.29434.1 & 5.57 & 2.57 & 1.60 & 3.50 & 0.45 & 1.36 & 0.08 & 0.63 & 1.97 & 0.38 \\
\hline MB.C. 29375 & 6.45 & 3.46 & 2.00 & 3.55 & 0.50 & 1.03 & 0.08 & 0.55 & 2.10 & 0.42 \\
\hline \multicolumn{11}{|c|}{ Lobotornoceras ausavense (Steininger, 1849) from the Sand Formation } \\
\hline MB.C.29388.1 & 7.78 & 4.50 & 2.85 & 3.40 & 0.35 & 0.76 & 0.04 & 0.44 & 2.49 & 0.37 \\
\hline MB.C.29388.2 & 8.40 & 5.00 & 2.90 & 3.45 & 0.25 & 0.69 & 0.03 & 0.41 & 2.33 & 0.42 \\
\hline \multicolumn{11}{|c|}{ Linguatornoceras cf. clausum (Glenister, 1958) from the Sand Formation } \\
\hline MB.C.29383 & 7.13 & 4.00 & - & - & 0.50 & - & 0.07 & - & - & - \\
\hline MB.C.29381 & 16.50 & 10.30 & 6.40 & 10.00 & 1.00 & 0.97 & 0.06 & 0.61 & 2.67 & 0.38 \\
\hline \multicolumn{11}{|c|}{ Linguatornoceras linguum (G. \& F. Sandberger 1850/56) from the Sand Formation } \\
\hline MB.C.29384.2 & 5.60 & 3.00 & - & 3.30 & 0.50 & 1.10 & 0.09 & 0.59 & - & - \\
\hline MB.C.29386.2 & 7.85 & 4.61 & - & 4.00 & 0.25 & 0.87 & 0.03 & 0.51 & - & - \\
\hline MB.C.29386.4 & 9.10 & 5.37 & 3.20 & 5.10 & 0.30 & 0.95 & 0.03 & 0.56 & 2.38 & 0.40 \\
\hline MB.C.29385 & 10.00 & 6.00 & - & 4.50 & 0.30 & 0.75 & 0.03 & 0.45 & - & - \\
\hline \multicolumn{11}{|c|}{ Linguatornoceras sp. 1 from the Sand Formation } \\
\hline MB.C.29387 & 5.40 & 2.30 & 1.50 & 2.25 & 0.40 & 0.98 & 0.07 & 0.42 & 1.92 & 0.35 \\
\hline
\end{tabular}


Stratigraphic range. Currently restricted to the upper Frasnian (UD I-I/J to UD I-K).

Genus Lobotornoceras Schindewolf, 1936

Lobotornoceras ausavense (Steininger, 1849), emended Figures 8j, 11c-f; Tables 1, 2

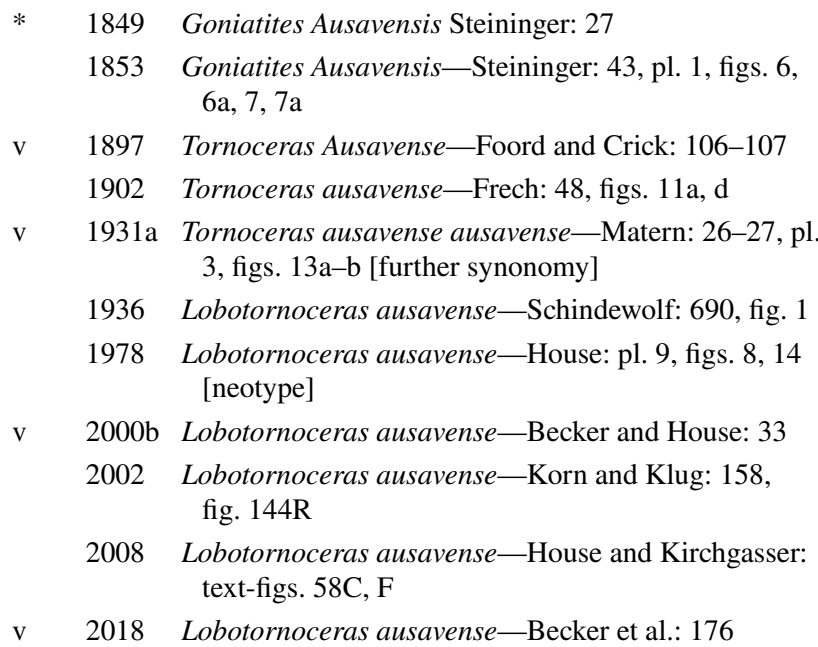

Neotype. SedgM H9932 (Sedgwick Museum of Earth Sciences, Cambridge), designated by House (1978).

Material. MB.C.29388.1, MB.C.29388.2, MB.C.29435.

Type locality. $250 \mathrm{~m}$ SSE of the Büdesheim Church, Eifel.

Type level. Büdesheim Goniatite Shale, upper Frasnian, UD $\mathrm{I}-\mathrm{I} / \mathrm{J}$.

Diagnosis (emended). Small-sized; conch thinly discoidal and weakly compressed (ww/dm $0.40-0.45$ and ww/wh 0.70 at $8 \mathrm{~mm} \mathrm{dm}$ ), involute (uw/dm $<0.10$ ), with very high whorl expansion rate (WER $2.30-2.50$ at $8 \mathrm{~mm} \mathrm{dm}$ ), with flattened flanks, narrowly rounded venter, and 4-6 weakly biconvex, later prorsiradiate and nearly convex varices per whorl that begin on the inner flanks and are strongest on the venter. Suture with moderately deep and wide, rounded, slightly divergent I-lobe, shallow and wide, internal $\mathrm{L}_{\mathrm{i}}$-lobe, small, low saddle at the umbilical seam, small, asymmetrically rounded $\mathrm{L}_{\mathrm{e}}$-lobe just outside the umbilicus, asymmetrically arched, high dorsolateral saddle, subsymmetric, moderately wide, well rounded A-lobe, high, narrow, asymmetrically rounded ventrolateral saddle, and small, narrow, short E-lobe.

Description. MB.C.29388.1 and MB.C.29388.2 display the $\mathrm{L}_{\mathrm{e}}$-lobe just outside the umbilicus as typical for Lobotornoceras (Figs. 8j, 11d-e). In the last septum of MB.C.29388.1, the $\mathrm{L}_{\mathrm{e}}$-lobe is deeper and closer to the umbilicus than the internal $\mathrm{L}_{\mathrm{i}}$-lobe (Fig. 11d). The secondary saddle dividing the L-lobe is, therefore, asymmetric, and thus not as in the illustration of Schindewolf (1936, compare his fig. 1). It is more symmetric in the second specimen, which fully displays the inner suture on the last septal face (Fig. 11f). There is no change of sutures between 4.5 and $8.3 \mathrm{~mm} \mathrm{dm}$. MB.C.29388.1 possesses a first biconvex varix with a shallow lateral sinus and subsequent subconvex and prorsiradiate varices (Fig. 11d). In MB.C.29435, the varices are rather weak. The cross-section is always weakly tegoid, with maximum ww on the inner flanks, and with a narrowly rounded venter. The umbilicus of the moulds is punctiform (uw/dm 0.03-0.04) and was probably sealed by shell.

Remarks. Matern (1931a) mentioned that biconvex varices following the growth lines occur only at later ontogenetic stages (ca $16 \mathrm{~mm} \mathrm{dm}$ ) but the neotype has four marked, weakly biconvex varices on the half whorl before ca. $9 \mathrm{~mm} \mathrm{dm}$ (from ca. $3.5 \mathrm{~mm}$ wh on). Specimens from Sand possess only subconvex varices except for the first in MB.C.29388.1. The Sand representatives are identical with the type material from Büdesheim. The older Lob. hassoni House, 1978 lacks varices, whilst the Russian Lob. strangulatum (Keyserling, 1844) is characterized by sutures with a

Table 3 Conch ontogeny of Crassotornoceras crassum (Matern, 1931b)

\begin{tabular}{|c|c|c|c|}
\hline $\mathrm{dm}$ & Conch shape & Whorl cross-section shape & Whorl expansion \\
\hline $2.5 \mathrm{~mm}$ & $\begin{array}{l}\text { Thinly pachyconic; subinvolute } \\
\text { (ww/dm } \sim 0.70 ; \mathrm{uw} / \mathrm{dm}=0.25 \text { ) }\end{array}$ & $\begin{array}{l}\text { Moderately depressed; - } \\
(\mathrm{ww} / \mathrm{wh} \sim 1.50 ;-)\end{array}$ & $\begin{array}{l}\text { Moderate } \\
(\text { WER 1.75) }\end{array}$ \\
\hline $4 \mathrm{~mm}$ & $\begin{array}{l}\text { Thinly pachyconic; subinvolute } \\
\text { (ww/dm } \sim 0.60 ; \mathrm{uw} / \mathrm{dm}=0.15 \text { ) }\end{array}$ & $\begin{array}{l}\text { Weakly depressed; strongly embracing } \\
\text { (ww/wh } \sim 1.15-1.30 ; \text { IZR } \sim 0.40 \text { ) }\end{array}$ & $\begin{array}{l}\text { Moderate } \\
\text { (WER } \sim 1.85-1.95)\end{array}$ \\
\hline $7 \mathrm{~mm}$ & $\begin{array}{l}\text { Thickly discoidal; subinvolute } \\
(\text { ww/dm } \sim 0.45-0.60 ; \text { uw/dm }=0.15 \text { ) }\end{array}$ & $\begin{array}{l}\text { Weakly depressed; very strongly embracing } \\
\text { (ww/wh } \sim 1.10 \text {; IZR } \sim 0.50 \text { ) }\end{array}$ & $\begin{array}{l}\text { Moderate } \\
\text { (WER } \sim 1.75-1.90)\end{array}$ \\
\hline
\end{tabular}


strongly asymmetric A-lobe and ventrolateral saddle (see Becker et al. 2000).

Stratigraphic range. Within the upper Frasnian, the Sand specimens extend the range of the species from UD I-I/J (Büdesheim; Tafilalt, Becker and House 2000b; Becker et al. 2018) to UD I-K. Close relatives (Lob. ausavense n. ssp. of Becker et al. 2004) occur, however, even earlier, in the upper part of the middle Frasnian (UD I-H).

\section{Genus Linguatornoceras House, 1965}

Linguatornoceras cf. clausum (Glenister, 1958), emended Figures 8k, 11g-h; Tables 1, 2

\footnotetext{
* 1958 Tornoceras (Tornoceras) clausum Glenister: 92-93, text-fig. 16A, C, pl. 15, figs. 7-9

v non 2000 Linguatornoceras aff. clausum-Becker et al.: 75, 77, 91, 93, fig. 7E (not 7D as stated in fig. caption), pl. 2, figs. $9-10$

v 2000 Linguatornoceras clausum-Becker et al.: 78, 79, 80, 93, 94, 96, 97, fig. 7F (not 7E as stated in fig. caption)

2002 Linguatornoceras clausum-Korn and Klug: 158, figs. $144 \mathrm{C}, \mathrm{P}$

non 2002 Linguatornoceras $\mathrm{sp}$. aff. L. clausum-Dzik: figs. $53 \mathrm{~K}-\mathrm{N}$ [= compressed Tornoceras $]$

cf. 2006 Linguatornoceras aff. clausum-Woroncowa-Marcinowska: 135-137, figs. 29A, 32A-B

e.p. 2008 Linguatornoceras linguum-House and Kirchgasser: 167, pl. 27, fig. 13 [non fig. $14=$ T. holwilli]
}

Holotype. 1756 (Geoscience Australia, formerly BMR, Canberra).

Material. MB.C.29381, MB.C.29382, MB.C.29383.

Type locality. Section RS 190, McWhae Ridge area, SE of Bugle Gap, Canning Basin of Western Australia.

Type level. Virgin Hills Formation, upper Frasnian. Glenister (1958) noted its co-occurrence with Ponticeras retorquatum, which enters at the base of UD I-J (Becker et al. 1993; Becker and House 2009).

Diagnosis (emended). Small-sized (up to ca. $50 \mathrm{~mm} \mathrm{dm}$ ); earliest stages until ca. $3 \mathrm{~mm} \mathrm{dm}$ cadiconic, with ww/dm decreasing from 0.80 to 0.70 , ww/wh decreasing from 2.50 to 1.60 , low whorl expansion rate (WER 1.60-1.70), and uw/dm reaching 0.20 ; after the third whorl gradually weakly depressed (until $6 \mathrm{~mm} \mathrm{dm}$ ) to increasingly compressed (ww/ wh down to $0.80-1.10$ ), thinly pachyconic, with umbilicus completely closing after the third whorl, at $20 \mathrm{~mm} \mathrm{dm}$ extremely high, slightly tegoid conch (WER 2.50-2.70), weakly compressed (ww/wh 0.70-0.90), with rounded umbilical wall, highest whorl width in the midflank area, and weakly rounded venter. Growth lirae strongly biconvex, with a wide lateral sinus, broad and high ventrolateral projection, and a deep, moderately wide, U-shaped ventral sinus. Suture with a moderately broad, asymmetrically arched, high dorsolateral saddle, deep, lingulate, markedly outwards curved A-lobe, high, asymmetric, obliquely rounded ventrolateral saddle with the same height as dorsolateral saddle, and a subparallel, narrow, short E-lobe.

Description. MB.C.29381 is the best-preserved specimen among the Sand material and fully septate at $16.5 \mathrm{~mm} \mathrm{dm}$ (Fig. 11g-h). In general, it resembles the larger Canning Basin types, especially in terms of sutures (Fig. 8k), whorl height (WER 2.67), and cross-section. However, it is somewhat more rotund, with a ww/wh of 0.97 , whilst the figured cross-section of Canning Basin paratype 1757 (Glenister 1958 ) suggests a rate of only $0.75-0.80$ at ca. the same size. A similar suture as in the types is visible on MB.C.29382 at only $4.6 \mathrm{~mm} \mathrm{dm}$. In contrast, MB.C.29383 is a partially preserved internal mould, which differs in a slightly shorter A-lobe. However, it is still deeper than the A-lobe of Tornoceras and slightly asymmetrical. All specimens are strictly involute, have rounded and slightly converging flanks, a rounded venter, and lack ventrolateral furrows. "Housean Pits" are preserved in MB.C.29383.

Remarks. The emended diagnosis employs the paratype cross-section of Glenister (1958). However, the intraspecific variability of the Canning Basin species has not yet been established and it is not clear whether there are possibly morphometric changes from zone to zone within the upper Frasnian. Due to the whorl width difference between our Sand specimens and the sectioned Australian paratype, we assign our material with a cf. to Ling. clausum. In Ling. linguum, the A-lobe is more symmetric. In Ling. yudinae it is very similar as in Ling. clausum but the species is characterized by a narrow ventrolateral furrow and dense ventral varices. Varices characterize also the poorly known Ling. restrictum (Eichwald, 1851). Based on the re-examination of its holotype, Ling. nummularium (Roemer, 1843) is much more compressed. All named Famennian linguatornoceratids possess a hook-shaped, subangular A-lobe. The middle Frasnian Ling. aff. clausum sensu Becker et al. (2000) and Becker and House (2009) combines Ling. linguum-type sutures with a rounded, tegoid cross-section; this form is intermediate between T. holwilli and Ling. clausum. 
Table 4 Adult characteristics of species within the genus Crassotornoceras

\begin{tabular}{|c|c|c|c|c|c|}
\hline Species & Cross-section & Size of umbilicus & Ribs & Varices & Furrows \\
\hline anissi & Weakly depressed & Open & None & 6-8 p. wh. & None \\
\hline belgicum & Weakly compressed & Open & Lateral & $3-5$ p. wh. & None \\
\hline aff. belgicum & Weakly compressed & Punctiform & Lateral & $3-5$ p. wh. & Weak \\
\hline crassum & Weakly depressed & Open & None & $3-5$ p. wh. & None \\
\hline hetzeneggeri sp. nov. & Weakly depressed & Punctiform & Weak, lateral & None & None \\
\hline isolatum & Weakly depressed & Open & Lateral & None & None \\
\hline nitidum & Weakly depressed & Open & None & $3-5$ p. wh., ventral & None \\
\hline nudum sp. nov. & Weakly compressed & Punctiform & None & None & None \\
\hline
\end{tabular}

Table 5 Conch ontogeny of Crassotornoceras belgicum (Matern, 1931b)

\begin{tabular}{llll}
\hline $\mathrm{dm}$ & Conch shape & Whorl cross-section shape & Whorl expansion \\
\hline $3 \mathrm{~mm}$ & Thinly pachyconic; subinvolute & Weakly depressed; moderately embracing & Moderate \\
& $($ ww/dm $\sim 0.65 ;$ uw/dm $=0.15-0.20)$ & $($ ww/wh $\sim 1.10-1.30 ;$ IZR $\sim 0.30)$ & $($ WER $\sim 1.90-1.95)$ \\
$6.5 \mathrm{~mm}$ & Thinly discoidal; involute & Weakly compressed; strongly embracing & High \\
& $($ ww/dm $\sim 0.45 ;$ uw $/ \mathrm{dm}=0.10-0.15)$ & $($ ww/wh $\sim 0.90-1.00 ;$ IZR $\sim 0.40)$ & $($ WER $\sim 2.00-2.10)$ \\
\hline
\end{tabular}

Stratigraphic range. In the Canning Basin type-region, the species enters at the base and ranges almost to the top of the upper Frasnian (UD I-I $\mathrm{I}_{1}$ to $\mathrm{I}-\mathrm{L}_{1}$ ). The same lower range is observed in the Timan (Becker et al. 2000). Unpublished material from the lower Famennian of the Cox Quarry in Bergisch Gladbach and from Nehden (both UD II-D) suggests that Ling. clausum or close relatives belonged to the few survivors of the global Kellwasser Crisis, but with a Lazarus Phase for the first six Famennian conodont zones (UD II-A to C).

Linguatornoceras linguum (Sandberger and Sandberger, 1851/52), emended

Figures 81, 11i, j; Tables 1, 2

\begin{tabular}{|c|c|c|}
\hline * & & $\begin{array}{l}\text { Goniatites retrorsus var. lingua Sandberger and Sand- } \\
\text { berger 1851: pl. 10, figs. 20-21; 1852: } 109\end{array}$ \\
\hline e.p. & 1895 & $\begin{array}{l}\text { Tornoceras simplex Mut. ovata Münster-Holzapfel: } \\
\text { fig. } 6 \text { [only] }\end{array}$ \\
\hline & 1908 & $\begin{array}{l}\text { Goniatites retrorsus var. lingua-Schöndorf: } 47 \\
\text { [lectotype] }\end{array}$ \\
\hline ion & 1965 & $\begin{array}{l}\text { Tornoceras (Linguatornoceras) aff. linguum-House: } \\
\text { 112-113, fig. 13E, pl. 9, figs. 82-83 [=T. holwilli] }\end{array}$ \\
\hline & $1993 a$ & $\begin{array}{l}\text { Linguatornoceras linguum-Becker: 188, figs. } 69 \mathrm{a}, \\
\text { 70d, pl. 3, figs. 13-14 [lectotype] }\end{array}$ \\
\hline & & $\begin{array}{l}\text { Linguatornoceras lingua-Korn and Klug: } 158 \text {, [non } \\
\text { figs. } 144 \mathrm{E}, \mathrm{H}=\text { L. haugi] }\end{array}$ \\
\hline
\end{tabular}

non 2008 Linguatornoceras aff. linguum-House and Kirchgasser: 167-168, text-figs. 56A-F, pl. 27, fig. 12, pl. 33, figs. $1-2,5-8$. tab. $26[=T$. holwilli and relatives]

non 2008 Linguatornoceras linguum-House and Kirchgasser: 167, pl. 27, figs. 13-14 [fig. 13= Ling. clausum, fig. $14=T$. holwilli $]$

Lectotype. MWNH-PA-SDB-55 (Museum Wiesbaden, Wiesbaden), designated by Becker (1993a).

Material. MB.C.29384.1, MB.C.29384.2, MB.C.29384.3, MB.C.29384.4, MB.C.29385, MB.C.29386.1, MB.C.29386.2, MB.C.29386.3, MB.C.29386.4, MB.C.29386.5, MB.C.29386.6, MB.C.29386.7.

Type locality. Büdesheim, Eifel.

Type level. Büdesheim Goniatite Shale, upper Frasnian, UD $\mathrm{I}-\mathrm{I} / \mathrm{J}$.

Diagnosis (emended). Small-sized; conch changing from thinly pachyconic and weakly depressed (ww/dm 0.65 and ww/wh 1.10 at $4 \mathrm{~mm} \mathrm{dm}$ ) gradually to thinly discoidal and increasingly compressed (ww/dm 0.40 and ww/wh 0.70 at $25 \mathrm{~mm} \mathrm{dm}$ ), with flattened, slightly converging flanks and a slender, rounded venter, and very high (WER 2.40 at $9 \mathrm{~mm} \mathrm{dm}$ ) to high (WER 2.10 at $25 \mathrm{~mm} \mathrm{dm}$ ) whorl expansion 

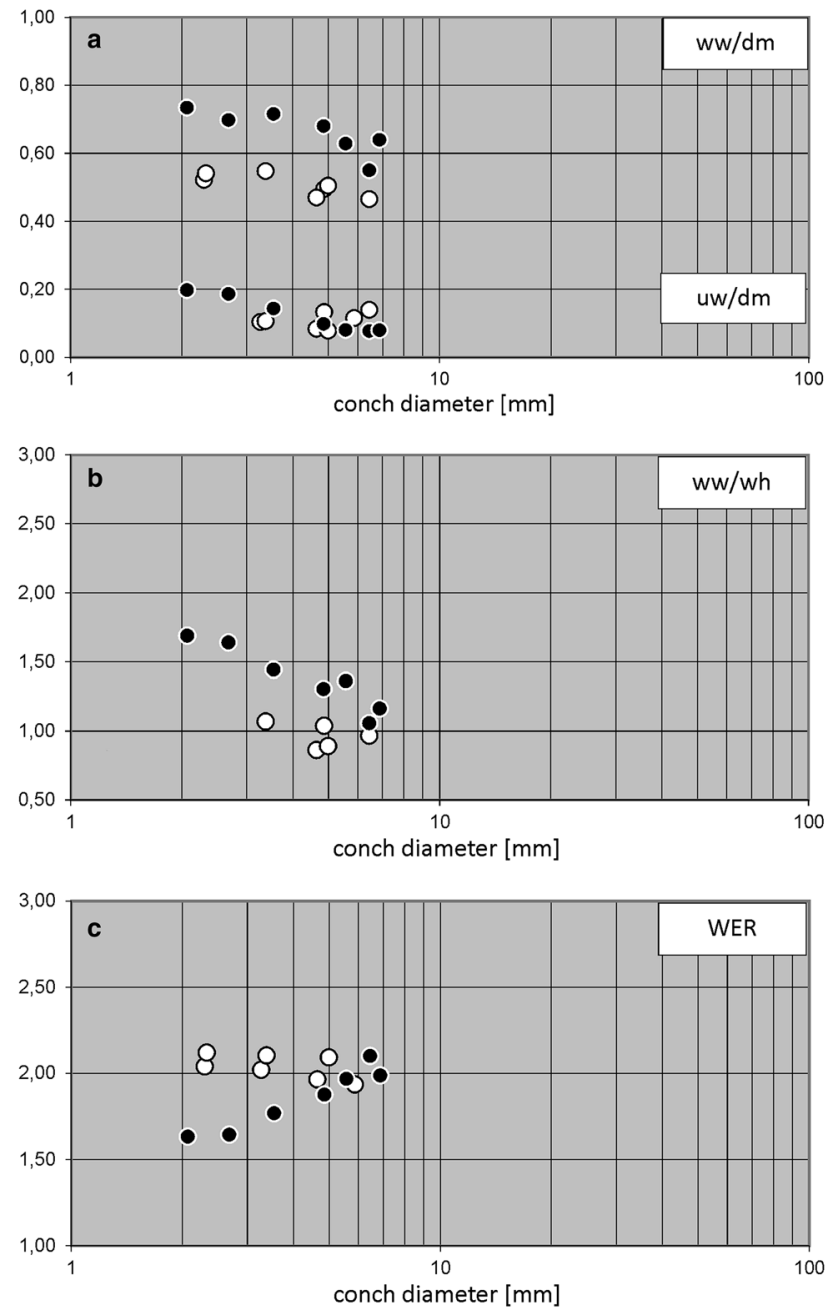

Fig. 10 Conch ontogeny of Crassotornoceras nudum sp. nov. (white circles) and $\mathrm{Cr}$. hetzeneggeri sp. nov. (black circles). a conch width index (ww/dm) and umbilical width index (uw/dm), b whorl width index (ww/wh), c whorl expansion rate (WER)

rate; umbilicus probably closed at maturity (uw/dm $<0.05)$ and no varices. Growth lines biconvex, with a broadly rounded lateral sinus, narrow, high ventrolateral projection, and relatively narrow ventral sinus. Suture with a broad, asymmetrically arched dorsolateral saddle, subsymmetric, deep, lingulate A-lobe, narrow, high, asymmetrically rounded ventrolateral saddle, and small, short, and narrow E-lobe.

Description. The Sand specimens range in size between $5.6 \mathrm{~mm}$ (MB.C.29384.2) and ca. $25 \mathrm{~mm}$ diameter (fragmentary MB.C.29386.5), the same size as the lectotype (Becker 1993a). Despite its limited preservation, MB.C.29386.5 can confirm that the species becomes thinly discoidal towards maturity. The best preserved specimens are MB.C.29386.2 (Fig. 11i-j) and MB.C.29386.4. The first is fully septate at $7.85 \mathrm{~mm} \mathrm{dm}$ and shows a deep, moderately wide, symmetrically rounded, lingulate A-lobe and a slightly divergent, short, narrow E-lobe (Fig. 81). Its umbilical margin is very short, from where the flanks converge towards a moderately narrow venter with rounded edges. MB.C.29386.4 is somewhat thicker (Table 2) and fully preserved at $9.1 \mathrm{~mm} \mathrm{dm}$. The body chamber occupies at least $180^{\circ}$. Partly, it displays the inner suture with a deep, narrowly rounded I-lobe. "Housean Pits" are preserved in MB.C.29386.3. Growth lines could not be observed on any specimen.

Remarks. Ontogenetic changes and intraspecific variability of the Büdesheim type population is part of ongoing research. In the Büdesheim lectotype, the A-lobe is somewhat narrower than in our specimens and slightly asymmetric whilst the ventrolateral saddle becomes as high as the dorsolateral saddle; this may reflect size differences and variability. Linguatornoceras aff. linguum sensu House (1965) and House and Kirchgasser (2008) lack a true lingulate A-lobe and are related to T. holwilli. In the middle Frasnian, Russian Ling. aff. clausum sensu Becker et al. (2000) the flanks are better rounded than in Ling. linguum and the ventrolateral saddle is slightly lower.

Stratigraphic range. UD I-I/J of Büdesheim to UD I-K of Sand, possibly ranging to the Frasnian top (UD I-L).

\section{Linguatornoceras $\mathrm{sp} .1$}

Figures 8m, 11k-1; Tables 1, 2

\section{Material. MB.C.29387.}

Description. The fully septate specimen MB.C.29387 is a well-preserved internal mould of $5.4 \mathrm{~mm}$ in diameter that shows shell form and sutures. The umbilicus is punctiform (uw/dm 0.07, Fig. 11k), with a very short, rounded umbilical wall. The conch is thinly discoidal and weakly compressed (ww/dm 0.42 and ww/wh 0.98), with a maximum whorl width on the inner flanks, converging from there with gentle curvature towards the slightly edged venter (Fig. 111). The whorl expansion rate is moderate (WER 1.92). There are no ribs, varices or impressed growth lines. The suture is distinctive because of the moderately wide, asymmetrically rounded A-lobe and the ventrolateral saddle that remains slightly lower than the strongly asymmetric, broad dorsolateral saddle. The sutural relief is moderate and the septal spacing of the last three sutures is reduced. Only a short part of the body chamber is preserved.

Remarks. The dense spacing of the last three sutures reflects slowed growth despite the small size, probably due to the onset of unfavourable environmental conditions (Davis et al. 1996; Kraft et al. 2008; Klug et al. 2015). Noteworthy are 


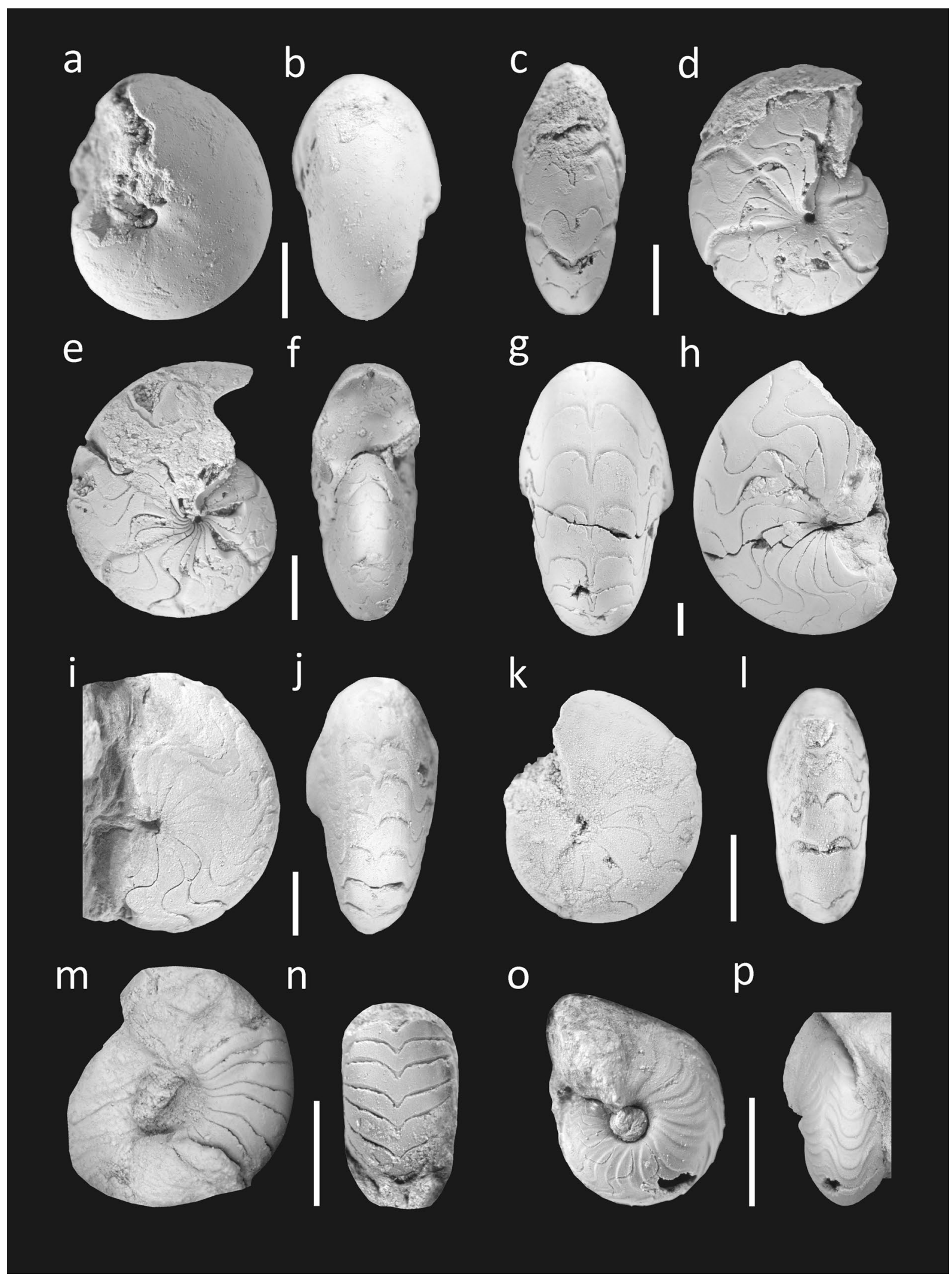


4Fig. 11 Tornoceratidae from the upper Frasnian Sand Formation (scale bar $2 \mathrm{~mm}$ ). a, b Crassotornoceras hetzeneggeri sp. nov., holotype MB.C.29375, showing the punctiform umbilicus, a wellrounded, pachyconic conch form, incipient dorsolateral ribbing, and traces of growth ornament with high ventrolateral projection; lateral and ventral views, Sand $3, \times 7$, c, d Lobotornoceras ausavense (Steininger, 1849), MB.C.29388.1, displaying five weakly biconvex to subconvex varices, an asymmetric subdivision of the L-lobe at the umbilical seam, and deep, symmetrical A-lobe; ventral and lateral views, Sand 3, ×6.5, e, f Lob. ausavense (Steininger, 1849), MB.C.29388.2, showing a symmetric subdivision of the L-lobe at the umbilical seam and the deep I-lobe; lateral and ventral views, Sand 3, ×6, g, h Linguatornoceras cf. clausum (Glenister, 1958), MB.C.29381, relatively thick specimen displaying the deep, asymmetrically lingulate A-lobe; ventral and lateral views, Sand 3, $\times 3, \mathbf{i}, \mathbf{j}$ Ling. linguum (Sandberger and Sandberger, 1850/51), MB.C.29386.2, weakly compressed mould with flattened flank and deep, lingulate A-lobe; lateral and ventral views, Sand A, $\times 6, \mathbf{k}, \mathbf{l}$ Ling. sp. 1, MB.C.29387, with slightly edged venter and asymmetrical A-lobe; lateral and ventral views, Sand A, $\times 8$, m, n Retrotornoceras juxi sp. nov., holotype MB.C.29393, with open umbilicus and simple suture lacking an A-lobe; lateral and ventral views, Sand 4, $\times 11, \mathbf{o}$, p Aulatornoceras auris (Quenstedt, 1846), MB.C.29346.4, with characteristic ventral festoons following the lateral growth line bundles; lateral and ventral views, Sand $1, \times 10$

"Housean Pits", which occur on both sides on the mid- and outer flanks. Linguatornoceras sp. 1 belongs to the group of early linguatornoceratids that lack varices, such as Ling. linguum, Ling. aff. clausum, and Ling. clausum. All three taxa are thicker at the same size $(\mathrm{ww} / \mathrm{dm}>0.50)$, still slightly depressed, and lack subangular ventral edges. The asymmetric shape of the A-lobe resembles Ling. clausum but the ventrolateral saddle is lower, which, however, could be a juvenile feature. In $T$. holwilli and the closely related $T$. typum, which shares with Ling. sp. 1 the flattened flanks, the A-lobe is more rounded and divergent, not lingulate. We prefer to put this species in open nomenclature, because only one specimen with signs of ecological stress ist available. More and better-preserved material from the Büdesheim locality is available.

Stratigraphic range. Restricted to the upper Frasnian (UD $\mathrm{I}-\mathrm{K})$.

Genus Retrotornoceras House, 2002

Retrotornoceras juxi sp. nov.

Figures 8n, 11m-n; Tables 1, 6

Etymology. After the late Prof. Ulrich Jux (Bergisch Gladbach, University of Cologne), who contributed during his lifetime a considerable amount to the knowledge of the Sand Formation.

Holotype. MB.C.29393 (Museum für Naturkunde Berlin).
Type locality. Sand 4, construction site at the Herkenrather Straße 70 of Bergisch Gladbach-Sand.

Type level. Sand Formation, upper Frasnian, UD I-K.

Diagnosis. Very small-sized; conch at ca. $5 \mathrm{~mm} \mathrm{dm}$ subinvolute (uw/dm 0.28), discoidal (ww/dm 0.45), weakly depressed (ww/wh 1.25), with rounded inner flanks and broad, gently rounded venter; indistinctive, concave flank varices. Suture simplified, with a shallow, widely rounded, dorsolateral L-lobe, low, broadly rounded dorsolateral saddle, an incipient, wide (reduced) A-lobe descending obliquely towards the small, narrow, V-shaped E-lobe.

Description. The holotype is a small, incomplete, fully septate internal mould representing ca. a half whorl. Its simple suture is very distinctive (Figs. 8 n, 11m-n) and characterized by a L-lobe extending considerably on the rounded umbilical wall. The A-lobe is very wide and extremely shallow in the first septa and completely reduced in later ones. The small E-lobe is pointed and divergent. Growth lines could not be observed. A shallow, concave flank varix occurs at the end of the preserved phragmocone (Fig. 11m).

Remarks. Despite its incomplete preservation, the morphology of our new form is very distinctive and unlike as in any other described Frasnian goniatite. The reduced A-lobe and general conch shape leads to an assignment to Retrotornoceras, a rare form that was previously only described from SW England (House 2002). The British Retro. alobatum is more slender and weakly compressed at $6 \mathrm{~mm} \mathrm{dm} \mathrm{(ww/wh}$ 0.81 ) and possesses a smaller umbilicus (uw/dm 0.15). Furthermore, its sutures seem to be even more reduced. Paratype NHM C18451 of Retro. alobatum (House 2002: pl. 3, fig. D) shows a dorsolateral L-lobe, as in our Retro. juxi sp. nov., but unlike as in the drawing of the holotype suture.

Stratigraphic range. Restricted to the upper Frasnian (UD I-K).

Subfamily Aulatornoceratinae Becker, 1993a (nom. transl. Korn and Klug 2002)

Genus Aulatornoceras Schindewolf, 1922

Remarks. Within Aulatornoceras, there are several species groups (see discussion in House and Kirchgasser, 2008), which need to be re-fined: In the Aul. auris Group, including also Aul. paucistriatum (D'Archiac and De Verneuil, 1842), Aul. rhysum (Clarke, 1898), Aul. bickense (Wedekind, 1918), Aul. constrictum (Steininger, 1849), Aul. serriense Becker, 1993a, Aul. steinhauseni sp. nov., Aul. frenklerae sp. nov. and Aul. tumidum House, 2002, the A-lobe is mostly lingulate, the ventral band often strong, and WER 
Table 6 Conch dimensions of Bergisch Gladbach-Sand Tornoceratidae [in mm]

\begin{tabular}{|c|c|c|c|c|c|c|c|c|c|c|}
\hline Specimen & $\mathrm{dm}$ & wh & ah & ww & uw & ww/wh & $\mathrm{uw} / \mathrm{dm}$ & $\mathrm{ww} / \mathrm{dm}$ & WER & IZR \\
\hline \multicolumn{11}{|c|}{ Retrotornoceras juxi sp. nov. from the Sand Formation } \\
\hline MB.C.29393 & 4.80 & 1.73 & - & 2.14 & 1.35 & 1.24 & 0.28 & 0.45 & - & - \\
\hline \multicolumn{11}{|c|}{ Aulatornoceras auris (Quenstedt, 1846) from the Sand Formation } \\
\hline MB.C.29346.1 & 3.41 & 1.74 & - & - & 0.53 & - & 0.16 & - & - & - \\
\hline MB.C.29346.4 & 3.55 & 1.73 & 1.00 & - & 0.70 & - & 0.20 & - & 1.94 & 0.35 \\
\hline MB.C.29346.3 & 4.63 & 2.40 & - & - & 0.72 & - & 0.16 & - & - & - \\
\hline MB.C. 29346.5 & 13.60 & 7.10 & - & 5.40 & 2.25 & 0.76 & 0.17 & 0.40 & - & - \\
\hline \multicolumn{11}{|c|}{ Aulatornoceras constrictum (Steininger, 1849) from the Sand Formation } \\
\hline MB.C.29349.2 & 2.35 & 1.20 & - & 1.60 & 0.45 & 1.33 & 0.19 & 0.68 & - & 0.38 \\
\hline MB.C.29348.1 & 5.39 & 2.37 & - & 3.10 & 1.20 & 1.31 & 0.22 & 0.58 & - & - \\
\hline MB.C.29348.2 & 6.80 & 3.09 & - & 3.85 & 1.46 & 1.25 & 0.21 & 0.57 & - & - \\
\hline MB.C.29349.1 & 7.06 & 3.34 & 2.00 & 3.00 & 1.26 & 0.90 & 0.18 & 0.42 & 1.95 & 0.40 \\
\hline \multicolumn{11}{|c|}{ Aulatornoceras aff. constrictum (Steininger, 1849) from the Sand Formation } \\
\hline MB.C.29355 & 3.10 & 1.45 & 0.93 & 1.70 & 0.52 & 1.17 & 0.17 & 0.55 & 2.05 & 0.36 \\
\hline \multicolumn{11}{|c|}{ Aulatornoceras eifliense (Steininger, 1849) from the Sand Formation } \\
\hline MB.C.29351.1 & 5.33 & 3.05 & 1.75 & 2.70 & 0.30 & 0.89 & 0.06 & 0.51 & 2.22 & 0.43 \\
\hline MB.C.29351.2 & 6.00 & 3.45 & 2.20 & 3.10 & 0.40 & 0.90 & 0.07 & 0.52 & 2.49 & 0.36 \\
\hline \multicolumn{11}{|c|}{ Aulatornoceras steinhauseni sp. nov. from the Sand Formation } \\
\hline MB.C.29356.4 & 3.77 & 2.00 & - & 1.85 & 0.60 & 0.93 & 0.16 & 0.49 & - & - \\
\hline MB.C. 29356.2 & 5.21 & 2.80 & - & - & 0.77 & - & 0.15 & - & - & - \\
\hline MB.C. 29356.3 & 5.67 & 3.00 & - & 2.50 & 0.60 & 0.83 & 0.11 & 0.44 & - & - \\
\hline MB.C.29356.1 & 5.83 & 3.24 & 2.00 & 3.00 & 0.60 & 0.93 & 0.10 & 0.51 & 2.32 & 0.38 \\
\hline \multicolumn{11}{|c|}{ Aulatornoceras frenklerae sp. nov. from the Sand Formation } \\
\hline MB.C.29359 (internal) & 3.80 & 2.20 & 1.25 & 2.62 & 0.55 & 1.19 & 0.14 & 0.69 & 2.22 & 0.43 \\
\hline MB.C.29357.2 & 4.00 & 2.00 & - & - & 0.40 & - & 0.10 & - & - & - \\
\hline MB.C.29359 (external) & 7.71 & 3.87 & 1.90 & 4.20 & 0.80 & 1.09 & 0.10 & 0.54 & 1.76 & 0.51 \\
\hline \multicolumn{11}{|c|}{ Aulatornoceras ventrosulcatum sp. nov. from the Sand Formation } \\
\hline MB.C.29360 & 4.05 & 2.10 & 1.32 & 2.20 & 0.60 & 1.05 & 0.15 & 0.54 & 2.20 & 0.37 \\
\hline \multicolumn{11}{|c|}{ Aulatornoceras aff. ventrosulcatum from the Sand Formation } \\
\hline MB.C.29354 & 3.00 & 1.50 & 0.85 & 1.80 & 0.60 & 1.20 & 0.20 & 0.60 & 1.95 & 0.43 \\
\hline
\end{tabular}

moderately high to high. The very poorly known $G$. discus Roemer, 1850 (re-named as G. simile by Giebel 1852 due to homonymy with a Carboniferous species) and G. ammonitoides Trenkner, 1867 may belong here, too (see discussion in Clarke, 1884). In the Aul. eifliense Group, including also Aul. posterior Becker, 1993a, Aul. schurbuschense Becker in Becker et al. (2016), and Aul. ventrosulcatum sp. nov. the umbilicus is narrower, the A-lobe also lingulate, the ventral band often weak, and WER high to extremely high. In advanced Famennian species, such as Aul. lepiferum Becker, 1993a and Aul. compressum (Grüneberg, 1925), the A-lobe is deep and wide, transitional towards Polonoceras. Some of the Sand specimens put in open nomenclature (Aul. aff. constrictum, Aul. aff. ventrosulcatum) could belong to a fourth, probably more ancestral group characterized by a wide A-lobe and low relief of the suture.
Aulatornoceras auris (Quenstedt, 1846), emended Figures 9e, 11o-p, 12a-b, 13a-b; Tables 1, 6, 7

\footnotetext{
* 1846 Goniatites auris Quenstedt: 64, pl. 3, figs. 7a-c

1958 Tornoceras (Aulatornoceras) auris auris-House: 181-183, pl. 20, figs. 1-2, 4, 6-8; pl. 22, fig. 4 [further synonomy there]

v 1985 Aulatornoceras auris-House and Price: pl. 16, figs. 5-7; pl. 17, figs. $1-7$. [pl. 17, figs. $1-4=$ neotype]

v cf. $\quad 2000$ Aulatornoceras cf. auris-Becker et al.: 78, fig. 4

cf. $\quad 2002$ Aulatornoceras cf. auris-Dzik: fig. 51D

2002 Aulatornoceras auris-Korn and Klug: 161, fig. 149A

e.p. 2002 Aulatornoceras auris-House: 276, figs. 3A-B, pl. 3, figs. B, C [fig. 3C =Aul. cf. auris]

2008 Aulatornoceras auris-House and Kirchgasser: 176, text-fig. 60G, pl. 31, figs. 2-3
} 
a

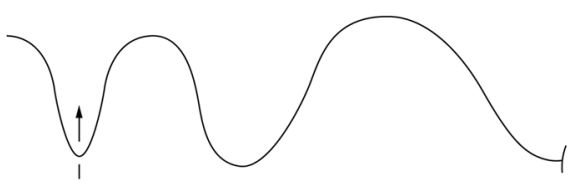

b

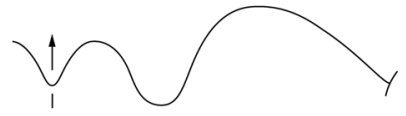

C

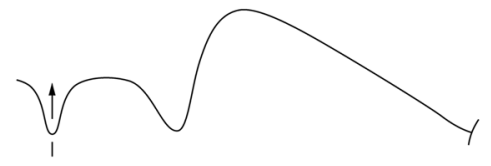

d

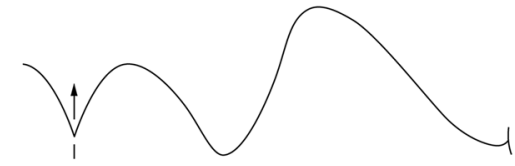

e

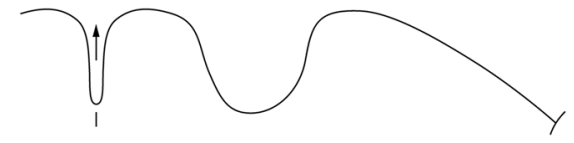

$\mathbf{f}$

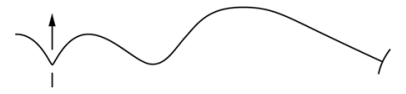

g

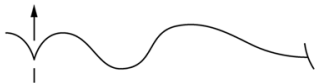

Fig. 12 Sutures of Aulatornoceratinae from Bergisch Gladbach-Sand. a Aulatornoceras auris (Quenstedt, 1846), MB.C.29346.5, Sand 1, at $4.00 \mathrm{~mm}$ wh, b Aul. auris (Quenstedt, 1846), MB.C.29346.4, Sand 1, at $1.10 \mathrm{~mm}$ wh, c Aul. constrictum (Steininger, 1849), MB.C.29348.2, Sand A, at $2.05 \mathrm{~mm}$ wh, d Aul. constrictum (Steininger, 1849), MB.C.29349.1, Sand A, at $2.14 \mathrm{~mm}$ wh, e Aul. eifliense (Steininger, 1849), MB.C.29353.1, Sand A, at $2.31 \mathrm{~mm}$ wh, f Aul. aff. ventrosulcatum, specimen MB.C.29354, Sand 1, at $1.05 \mathrm{~mm}$ wh, g Aul. aff. constrictum (Steininger, 1849), specimen MB.C.29355, Sand 1, at h

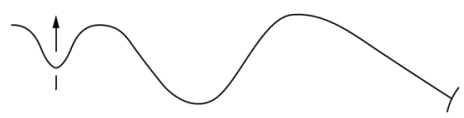

i

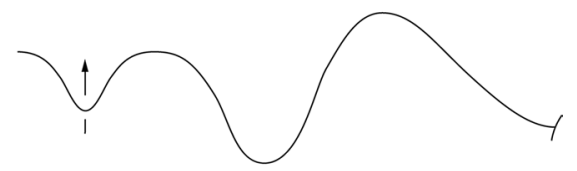

j

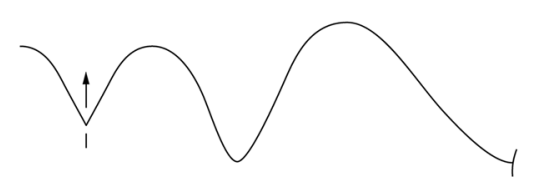

$\mathbf{k}$

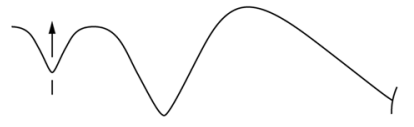

I

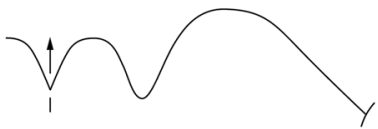

m

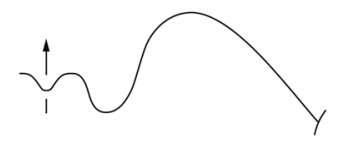

Table 7 Conch ontogeny of Aulatornoceras auris (Quenstedt, 1846)

\begin{tabular}{|c|c|c|c|}
\hline $\mathrm{dm}$ & Conch shape & Whorl cross-section shape & Whorl expansion \\
\hline $2.5 \mathrm{~mm}$ & $\begin{array}{l}\text { Thinly pachyconic; subinvolute } \\
\text { (ww/dm } \sim 0.65 ; \mathrm{uw} / \mathrm{dm}=0.20-0.25 \text { ) }\end{array}$ & $\begin{array}{l}\text { Moderately depressed; strongly embracing } \\
\text { (ww/wh 1.60; IZR 0.35) }\end{array}$ & $\begin{array}{l}\text { Moderate } \\
\text { (WER 1.80) }\end{array}$ \\
\hline $10 \mathrm{~mm}$ & $\begin{array}{l}\text { Thickly discoidal; subinvolute } \\
\text { (ww/dm } \sim 0.50 ; \mathrm{uw} / \mathrm{dm}=0.15-0.20 \text { ) }\end{array}$ & $\begin{array}{l}\text { Weakly depressed; strongly embracing } \\
\text { (ww/wh } \sim 1.00-1.20 ; \text { IZR } \sim 0.35-0.40 \text { ) }\end{array}$ & $\begin{array}{l}\text { Moderate } \\
(\text { WER 1.75-1.85) }\end{array}$ \\
\hline $16 \mathrm{~mm}$ & $\begin{array}{l}\text { Thinly discoidal; subinvolute } \\
(\mathrm{ww} / \mathrm{dm} \sim 0.40-0.45 ; \mathrm{uw} / \mathrm{dm}=0.15)\end{array}$ & $\begin{array}{l}\text { Weakly compressed;- } \\
\text { (ww/wh } \sim 0.75-0.80 ;- \text { ) }\end{array}$ & $\begin{array}{l}\text { Moderate } \\
\text { (WER 1.85) }\end{array}$ \\
\hline
\end{tabular}

Neotype. SedgM H9943 (Sedgwick Museum of Earth Sciences, Cambridge), designated by House and Price (1985).
Material. MB.C.29346.1, MB.C.29346.2, MB.C.29346.3, MB.C.29346.4, MB.C.29346.5, MB.C.29347. 
Table 8 Conch ontogeny of Aulatornoceras constrictum (Steininger, 1849)

\begin{tabular}{llll}
\hline $\mathrm{dm}$ & Conch shape & Whorl cross-section shape & Whorl expansion \\
\hline $2.5 \mathrm{~mm}$ & Thinly pachyconic; subinvolute & Weakly depressed; moderately embracing & Moderate \\
& $($ ww/dm $\sim 0.70 ;$ uw/dm $=0.20)$ & $($ ww/wh $\sim 1.45 ;$ IZR $\sim 0.25)$ & (WER $\sim 1.85)$ \\
$7 \mathrm{~mm}$ & Thinly discoidal; subinvolute & Weakly compressed; strongly embracing & $\begin{array}{l}\text { Moderate } \\
\end{array}$ \\
& $($ ww/dm $\sim 0.40-0.50 ;$ uw $/ \mathrm{dm}=0.15)$ & $($ ww/wh $\sim 0.90-1.00 ;$ IZR $\sim 0.40)$ & $($ WER $\sim 1.95)$ \\
\hline
\end{tabular}

Type locality. Büdesheim, Eifel.

Type level. Büdesheim Goniatite Shale, upper Frasnian, UD I-I/J.

Diagnosis (emended). Very small-sized; early stages thinly pachyconic and moderately depressed (ww/dm 0.65 and ww/ wh 1.60 at $2.5 \mathrm{~mm} \mathrm{dm}$ ), becoming gradually thinly discoidal and weakly compressed (ww/dm $0.40-0.45$ and ww/wh $0.75-0.80$ at $16 \mathrm{~mm} \mathrm{dm}$ ), subinvolute (uw/dm $0.15-0.25$ between 5 and $15 \mathrm{~mm} \mathrm{dm}$ ), relatively constant whorl expansion rates (WER 1.75-1.95), with short, rounded umbilical wall, gently rounded flanks, and flattened venter, bordered at maturity by ventrolateral edges; no varices. Strongly biconvex, bundled growth lines with low and broad dorsolateral salient, wide lateral sinus, very prominent, narrow ventrolateral projection lying in a spiral furrow, and a deep, U-shaped ventral sinus. The lateral bundles continue on the venter as festoons of a marked ventral band; bundle density and festoon numbers increase with growth. Suture with a broad, asymmetrically ascending dorsolateral saddle, deep and narrow, lingulate, slightly asymmetric A-lobe, moderately broad, asymmetrically rounded ventrolateral saddle that remains slightly lower than the dorsolateral saddle, and very narrow, slightly divergent E-lobe.

Description. MB.C.29346.5 is the largest representative from Sand reaching $13.6 \mathrm{~mm} \mathrm{dm}$, which is larger than the neotype $(9 \mathrm{~mm} \mathrm{dm})$ but smaller than an incomplete topotype figured by House and Price (1985: pl. 17, figs. 5-7, 19-20 mm dm). Our specimens display the characteristic, strongly biconvex, bundled growth lines with broad lateral sinus, very high, tongue-shaped ventrolateral projection, and deep, moderately wide ventral sinus (Figs. 9e, 12a-b). In MB.C.29346.5, the ventral festoons are weaker and more closely spaced than in the neotype, resembling the ornament of the mentioned larger topotype. There are three finer lirae between the main lirae marking individual chapters of the ventral band. Other, smaller specimens display variably similar (MB.C.29347) or stronger bundles and festoons (MB.C.29346.4, Fig. 11o-p). In general, the ornament tends to get finer with growth. There is a limited intraspecific variation of umbilical width, where MB.C.29346.5 is a typical specimen (uw/dm 0.17), while the umbilicus of MB.C.29346.4 is slightly wider at a smaller size (uw/dm
0.20). The comparison of juvenile (MB.C.29346.4, Fig. 12b) and adult (MB.C.29346.5, Fig. 12a) sutures show that the ventrolateral saddle rises during ontogeny, but without reaching the height of the dorsolateral saddle.

Remarks. Aulatornoceras auris is defined by the lack of true varices. In the neotype of House and Price (1985), the strong flank bundles and festoons produce 12 shallow depressions per whorl that slightly resemble varices. But this type of ornament is different from the much more widely-spaced regular varices on the mould of the otherwise similar Aul. constrictum and of the much thicker Aul. tumidum. Some specimens of Aul. auris from Büdesheim suggest, that the umbilicus can be more open in juvenile stages (uw/dm up to 0.30). Aulatornoceras paucistriatum is even more evolute (uw/dm >0.30). The North American Aul. rhysum is very close, if not conspecific with Aul. auris, and displays even stronger flank bundles and ventral festoons.

Stratigraphic range. So far restricted to the upper Frasnian (UD I-I to UD I-L).

Aulatornoceras constrictum (Steininger, 1849)

Figures 9f, 12c-d, 13c-j; Tables 1, 6, 8

* 1849 Goniatites constrictus Steininger: 27

1853 Goniatites constrictus-Steininger: 43, pl. 1, fig. 9

1902 Tornoceras constrictum - Frech: 49, figs. 11b-c

1918 Tornoceras constrictum -Wedekind: 136

non 1925 Tornoceras (Aulatornoceras) ?constrictum-Grüneberg: 67, pl. 1, fig. 11 [= juvenile Ling. guestphalicum]

v cf. 2000 Aulatornoceras bickense-Becker et al.: fig. 9F; pl. 4, figs. 7-8

cf. 2002 Aulatornoceras belgicum-Dzik: figs. 52B-C, 53P-R, $54 \mathrm{I}-\mathrm{M}, 56 \mathrm{~N}-\mathrm{P}$

cf. 2002 Aulatornoceras bickense-House: 276, pl. 2, figs. M-N

Type. The Steininger Collection has been lost. A neotype from Büdesheim is required.

Material. MB.C.29348.1, MB.C.29348.2, MB.C.29349.1, MB.C.29349.2, MB.C.29349.3, MB.C.29349.4.

Type locality. Büdesheim, Eifel. 
Type level. Büdesheim Goniatite Shale, upper Frasnian, UD $\mathrm{I}-\mathrm{I} / \mathrm{J}$.

Diagnosis. see Steininger (1849).

Description. The early juvenile MB.C.29349.2 is weakly pachyconic, weakly depressed (ww/dm ca. 0.70 and ww/ wh ca. 1.35 at $2.35 \mathrm{~mm} \mathrm{dm}$ ), and subinvolute (uw/dm $0.19)$. An ontogenetic change of the conch is expressed by MB.C.29349.1 (Fig. 13g-h), which has a subevolute (uw/ $\mathrm{dm} 0.18$ at $7 \mathrm{~mm} \mathrm{dm}$ ), weakly compressed (ww/wh 0.90 ), discoidal (ww/dm 0.42) conch with a short umbilical wall, gently rounded flanks, and moderately wide, slightly edged venter. It displays four distinctive varices on the last whorl, which follow the biconvex growth lines characterized by a high and very narrow ventrolateral projection lying in a moderately developed ventrolateral furrow. The ventral sinus is $\mathrm{U}$-shaped, with a relatively flat base, and not as deep as the lateral sinus (Fig. 9f). The last whorl is mostly (ca. $280^{\circ}$ ) occupied by the body chamber; the specimen was mesodomic. The suture (Fig. 12d) contains a L-lobe extending onto the umbilical wall, a broad, very highly arched, asymmetrically rounded dorsolateral saddle, a deep, slightly asymmetric and rounded-subtriangular A-lobe, a curved, moderately broad ventrolateral saddle that reaches roughly $2 / 3$ of the height of the dorsolateral saddle, and a divergent, V-shaped E-lobe. MB.C.29349.4 (Fig. 13i-j) differs from typical specimens by its rather chevron-shaped varices on the venter. Its cross-section is tegoid, the umbilicus more punctiform, but the weakly compressed, discoidal conch (ww/dm 0.50 at ca. $6 \mathrm{~mm} \mathrm{dm}$ ) fits into the ontogenetic trend. Both specimens, MB.C.29348.1 (Fig. 13c-d) and MB.C.29348.2 (Fig. 13e-f), represent slightly thicker variants of Aul. constrictum (see Table 6).

Remarks. The original illustration by Steininger (1853) showed a strongly involute, ca. $11.5 \mathrm{~mm}$ large goniatite from Büdesheim with slightly compressed, tegoid cross-section, high whorl expansion rate (WER 2.00), and three marked, biconvex varices on the last whorl. The illustration by Frech (1902) agrees in terms of whorl expansion rate, varices, and sutures. A correct understanding and emended diagnosis of Aul. constrictum depends on a future neotype. Until this neotype and a new type for Aul. bickense are selected, both species can not be distinguished properly. The small, lower Famennian Aul. schurbuschense (Aul. auriforme in Becker 1993a) differs in a very small (punctiform) umbilicus, lamellose ornament, weaker ventrolateral furrows, irregular spacing of the varices, and even smaller, lower ventrolateral saddle.

Stratigraphic range. Currently restricted to the upper Frasnian (UD I-I/J to UD I-K).
Aulatornoceras aff. constrictum (Steininger, 1849)

Figures 12g, 13p-q; Tables 1, 6

Material. MB.C.29355.

Description. The only available specimen MB.C.29355 possesses a thickly discoidal and weakly depressed conch (ww/ $\mathrm{dm} 0.55$ and ww/wh 1.17 at ca. $3 \mathrm{~mm} \mathrm{dm}$ ). It is subinvolute (uw/dm 0.17) and the whorl expansion rate is high (WER 2.05). The small specimen shows a tegoid whorl form with a maximum whorl width on the dorsolateral part of the flanks near the short, rounded umbilicall wall. Its body chamber occupies at least $190^{\circ}$ (Fig. 13p-q). The rounded venter is bordered by ventrolateral double furrows, with weak U-shaped varices forming a weak ventral band displaying several intercalated growth lirae on each field (Fig. 13q). Impressions of the growth lines could not be observed on the internal mould. The suture is only moderately well preserved (Fig. 13p) and has a generally low relief, a dorsolaterally extended L-lobe, a low, broadly rounded dorsolateral saddle, a moderately wide and shallow, subsymmetric A-lobe, a small and low ventrolateral saddle, and a short, pointed, divergent E-lobe (Fig. 12g).

Remarks. The specimen differs from the closely related Aul. constrictum and Aul. aff. ventrosulcatum by its characteristic ventrolateral double furrows. Furthermore, no other aulatornoceratid possesses similar sutures even at juvenile stages. We prefer to put it in open nomenclature until more material allows to better characterize this probably new species.

Stratigraphic range. Restricted to the upper Frasnian (UD $\mathrm{I}-\mathrm{K})$.

Aulatornoceras eifliense (Steininger, 1849), emended Figures 9g, 10e, 13k-m; Tables 1, 6, 9

\begin{tabular}{|c|c|c|}
\hline$*$ & 1849 & Goniatites eifliensis Steininger: 27 \\
\hline e.p. & 1853 & $\begin{array}{l}\text { Goniatites eifliensis-Steininger: pl. 1, figs. 2, 2a } \\
\text { [non pl. 1, figs. 3, 3a=Aul. cf. auris; see Foord } \\
\text { and Crick 1897, Wedekind 1918, and Becker } \\
\text { 1993a] }\end{array}$ \\
\hline v e.p. & $1850 / 51$ & $\begin{array}{l}\text { Goniatites retrorsus var. undulatus - Sandberger } \\
\text { and Sandberger: 103, 109, pl. 10, figs. 19a-c } \\
\text { [neotype; ?pl. 10, fig. 18, non pl. 10, fig. 17, } \\
\text { 17a = lectotype of Truyolsoceras sandbergeri, non } \\
\text { pl. 10a = ?Falcitornoceras korni] }\end{array}$ \\
\hline e.p. & 1902 & Tornoceras undulatus -Frech: 49, figs. 12a, b [only] \\
\hline $\mathrm{v}$ & 1908 & $\begin{array}{l}\text { Goniatites retrorsus var. undulatus-Schöndorf: } 47 \\
\text { [neotype] }\end{array}$ \\
\hline & 1918 & Tornoceras eifliense-Wedekind: 137 \\
\hline & 1993 & $\begin{array}{l}\text { Aulatornoceras eifliense-House and Kirchgasser: } \\
276\end{array}$ \\
\hline
\end{tabular}


Table 9 Conch ontogeny of Aulatornoceras eifliense (Steininger, 1849)

\begin{tabular}{llll}
\hline $\mathrm{dm}$ & Conch shape & Whorl cross-section shape & Whorl expansion \\
\hline $5.5 \mathrm{~mm}$ & Thickly discoidal; involute & Weakly compressed; strongly embracing & Very high \\
& $($ ww $/ \mathrm{dm} \sim 0.50 ;$ uw $/ \mathrm{dm}=0.05-0.10)$ & $($ ww/wh $\sim 0.80-1.00 ;$ IZR $\sim 0.35-0.45)$ & $($ WER $\sim 2.30-2.50)$ \\
$8 \mathrm{~mm}$ & Thickly discoidal; involute & Weakly compressed; strongly embracing & Very high \\
& $($ ww $/ \mathrm{dm} \sim 0.55-0.60 ;$ uw $/ \mathrm{dm} \sim 0.10)$ & $($ ww/wh $\sim 0.80-0.90 ;$ IZR $\sim 0.35)$ & $($ WER $\sim 2.45-2.50)$ \\
\hline
\end{tabular}

Table 10 Conch ontogeny of Aulatornoceras steinhauseni sp. nov.

\begin{tabular}{llll}
\hline $\mathrm{dm}$ & Conch shape & Whorl cross-section shape & Whorl expansion \\
\hline $4 \mathrm{~mm}$ & $\begin{array}{l}\text { Thickly discoidal; subinvolute } \\
(\text { ww/dm } \sim 0.50 ; \text { uw/dm }=0.15)\end{array}$ & Weakly compressed;- & - \\
& $\begin{array}{l}\text { Thinly discoidal; involute } \\
(\text { ww } / \mathrm{dm} \sim 0.45 ; \text { uw } / \mathrm{dm}=0.10)\end{array}$ & Weakly compressed; strongly embracing & Very high \\
& $($ ww/wh $\sim 0.85 ;$ IZR $\sim 0.40)$ & $($ WER $\sim 2.30)$ \\
\hline
\end{tabular}

1993a Aulatornoceras eifliense eifliense-Becker: 216, pl.
9, figs. 4-6 [neotype]
$2008 \quad \begin{gathered}\text { Aulatornoceras eifliense-House and Kirchgasser: } \\ \text { 176-177, pl. 31, figs. 7-13, 16-20; tab. 31 }\end{gathered}$

Neotype. MWNH-PA-SDB-54 (Museum Wiesbaden, Wiesbaden), selected by Becker (1993a).

Material. MB.C.29350, MB.C.29351.1, MB.C.29351.2, MB.C.29352, MB.C.29353.1, MB.C.29353.2, MB.C.29353.3, MB.C.29353.4.

Type locality. Büdesheim, Eifel.

Type level. Büdesheim Goniatite Shale, upper Frasnian, UD $\mathrm{I}-\mathrm{I} / \mathrm{J}$.

Diagnosis (emended). Small-sized; median stages (5-6 mm dm) thickly discoidal (ww/dm 0.50-0.55), weakly compressed (ww/wh ca. 0.90), involute (uw/dm ca. 0.07), with high whorls (WER 2.25-2.50), towards maturity increasingly compressed, thickly discoidal (ww/wh 0.70 0.75 and ww/dm ca. 0.45 at ca. $19 \mathrm{~mm} \mathrm{dm}$ ), with punctiform umbilicus, and very high whorls (WER ca. 2.50), tegoid cross-section (max. ww near the short, rounded umbilical wall), with weakly rounded venter bordered by canaliculate, narrow, ventrolateral furrows forming a minor, outer spiral ridge; no varices. Growth lines strongly biconvex, with short and low dorsolateral salient, wide lateral sinus, narrow and very high ventrolateral projection, and deep, U-shaped, moderately wide ventral sinus. Suture with an asymmetric, broad, highly arched dorsolateral saddle, deep, symmetrically rounded, lingulate A-lobe, high and slender ventrolateral saddle, and deep, narrowly rounded E-lobe.
Description. All sand specimens share a very high whorl expansion rate (WER 2.20-2.50) as well as a thickly discoidal and involute conch shape. Based on the comparison with the Büdesheim neotype, it seems that WER rates increase with growth whilst the umbilicus becomes extremely narrow. MB.C.29351.1 (Fig. 13k-m) closely resembles the neotype. As shown in Fig. 131, its body chamber exceeds $220^{\circ}$ (ca. $270^{\circ}$ in the neotype). Growth lines are dense, weakly bundled (undulose) and display a high and narrow ventrolateral projection and broad, U-shaped ventral sinus (Fig. 9g). There is no marked ventral band; the ventral growth lirae are relatively closely spaced. The suture of MB.C.29353.1 (Fig. 11e) displays a broad, highly arched dorsolateral saddle, a subsymmetric, deeply rounded A-lobe, and a relatively narrow ventrolateral saddle, which reaches the height of the dorsolateral saddle. All Sand specimens show a very narrow and deep, scarcely rounded E-lobe, as in the neotype.

Remarks. The Sand specimens are very close to the neotype from Büdesheim. Aulatornoceras eifliense is part of a separate lineage within Aulatornoceras defined by high apertures and small umbilici (Becker 1993a). This lineage seems to have survived the Frasnian-Famennian boundary in parallel with the Aul. auris Group, giving rise in the lower Famennian to Aul. posterior.

Stratigraphic range. Ranges from the middle Frasnian (UD I-F) to upper Frasnian (UD I-K); but probably survived the Frasnian-Famennian boundary.

Aulatornoceras steinhauseni sp. nov. Figures 2a-f, 9i, 12h; Tables 1, 6, 10 
Etymology. After Harald Steinhausen (Cologne), for collecting some of the specimens of this publication and for his long, dedicated work in the regional palaeontological community.

Holotype. MB.C.29356.1 (Museum für Naturkunde Berlin).

Paratypes. MB.C.29356.2, MB.C.29356.3, MB.C.29356.4.

Type locality. Sand 1, construction site at the Herkenrather Straße 70 of Bergisch Gladbach-Sand.

Type level. Sand Formation, upper Frasnian, UD I-K.

Diagnosis. Very small-sized; conch changing between ca. 4-6 mm dm from thickly (ww/dm 0.50) to thinly discoidal (ww/dm 0.45), becoming increasingly compressed (from ww/wh 0.95 down to 0.85 ), more involute (uw/dm from 0.15 down to 0.10 ), always with strongly tegoid cross-section, very high whorls (WER ca. 2.30), and narrowly rounded venter bordered by weak to only incipient ventrolateral furrows. Strongly biconvex, undulose or bundled growth lines with short and low dorsolateral salient, wide lateral sinus, very high, narrow, subtriangular ventrolateral projection, and very deep, divergent, nearly V-shaped ventral sinus lying in a ventral band demarcated by fine lirae and prominent ventral varices that follow the course of the growth lines. Suture with a broad, asymmetrically arched dorsolateral saddle, moderately wide, asymmetrically rounded A-lobe, a moderately narrow, asymmetrically rounded ventrolateral saddle that is lower than the dorsolateral saddle, and short, divergent E-lobe.

Description. Holotype MB.C.29356.1 (Figs. 2c-d, 12h) is an internal mould of ca. $6 \mathrm{~mm} \mathrm{dm}$ that shows the suture, the typical tegoid cross-section, the narrow umbilicus (uw/ $\mathrm{dm} 0.10$ ) bordered by a short, rounded umbilical wall, and the ventrolateral furrow that become only distinctive on the body chamber, which occupies ca. the last half whorl. It shows well the characteristic, bundled, strongly biconvex growth lines with the high ventrolateral projection and deep, divergent, near $\mathrm{V}$-shaped ventral sinus. There are seven, more or less equally spaced, also V-shaped ventral varices on the body chamber, which define festoons of the ventral band that correspond strictly to the lateral growth line bundles. Each festoon bears one or two, widely spaced, fine growth lirae. The suture is characterized by a moderately broad dorsolateral saddle that ascends obliquely from the umbilicus, a relatively wide and asymmetric, Tornocerastype A-lobe, and the ventrolateral saddle that remains lower than the dorsolateral saddle during ontogeny.

On paratype MB.C.29356.4 (Fig. 2a-b), the lateral growth line bundles resemble those of Aul.auris but on the venter they are divergent, again with ca. two distinctive and widely spaced growth lirae per festoon. The ventrolateral projections do not lie in a distinctive furrow. The uw/dm ratio of 0.16 at ca. $3.8 \mathrm{~mm}$ dm suggests that the umbilicus does not open with growth in the species, resulting in decreasing relative proportions. Sutures are similar as in the holotype, again with a relatively wide A-lobe and low, asymmetric, obliquely rising ventrolateral saddle. Paratypes MB.C.29356.2 and MB.C.29356.3 (Fig. 2e-f) are similar to each other, display the typical suture, and, in constrast to larger specimens, both lack ventrolateral furrows at a small size. All specimens share isolated ventral growth lirae sitting in variably positions of a longer festoon (Fig. 2b-c, e).

Remarks. In terms of ornament, some variants of Aul. auris resemble Aulatornoceras steinhauseni sp. nov. (Fig. 11o-p) but these lack ventral varices and posses a narrower, lingulate A-lobe. The lower Famennian Aul. lepiferum can be easily distinguished by its tabulate venter with ventral edges and sutures with a higher, narrow ventrolateral saddle. Aulatornoceras ventrosulcatum sp. nov. lacks a prominent festoon-like ornament and the varices of Aul. constrictum reach the umbilicus.

Stratigraphic range. Restricted to the upper Frasnian (UD $\mathrm{I}-\mathrm{K})$.

Aulatornoceras frenklerae sp. nov. Figures 2g-k, 12i-l; Tables 1, 6, 11

Etymology. Named after Helga Frenkler (Odenthal) for collecting and providing some of the specimens of this publication and for her ongoing contributions to the regional palaeontological community.

Holotype. MB.C.29359 (Museum für Naturkunde Berlin).

Paratypes. MB.C.29357.1, MB.C.29357.2, MB.C.29358.

Type locality. Sand 1, construction site at the Herkenrather Straße 70 of Bergisch Gladbach-Sand.

Type level. Sand Formation, upper Frasnian, UD I-K.

Diagnosis. Very small-sized; conch changing between ca. 4 and $8 \mathrm{~mm} \mathrm{dm}$ from thinly pachyconic (ww/dm 0.65-0.70) to thickly discoidal (ww/dm $0.50-0.55$ ), becoming gradually less depressed (from ww/wh 1.15-1.20 down to 1.051.10), always involute (uw/dm 0.10), with decreasing whorl expansion rates (WER 2.20 down to 1.80), well-rounded flanks and venter, developing only late in ontogeny incipient ventrolateral furrows; with widely spaced, strongly biconvex varices on the flanks and venter and weak ventral band. Suture with a deep, pointed I-lobe, rounded L-lobe 


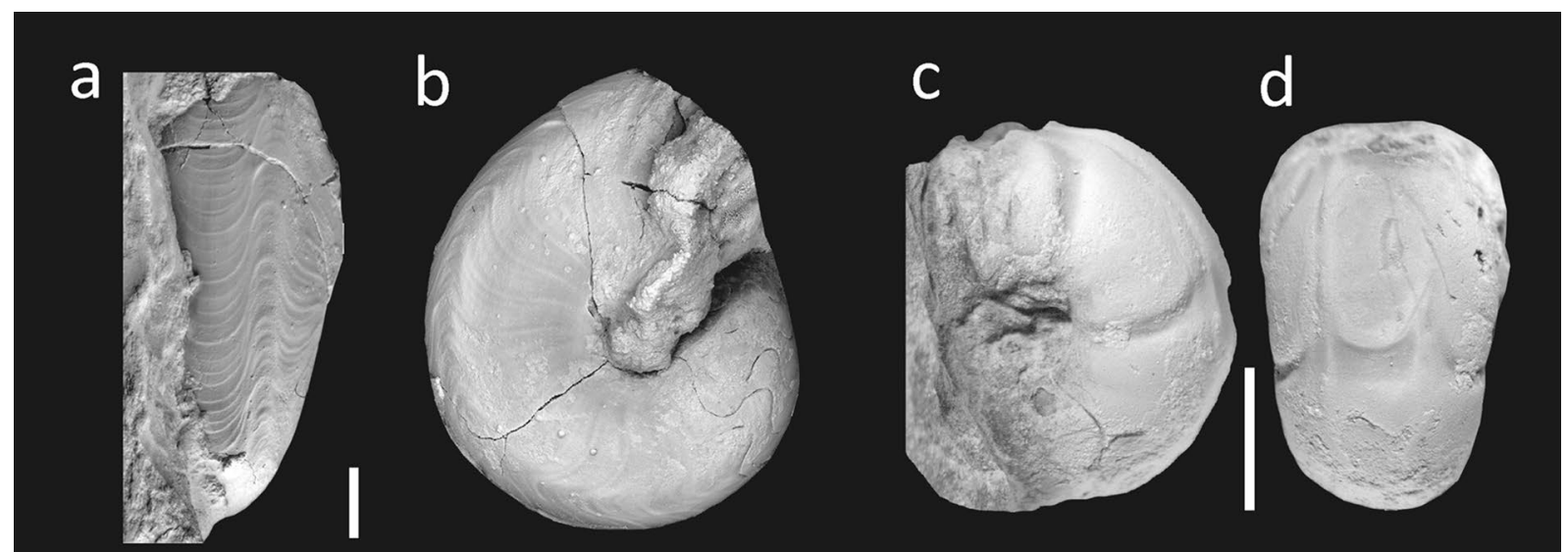

e
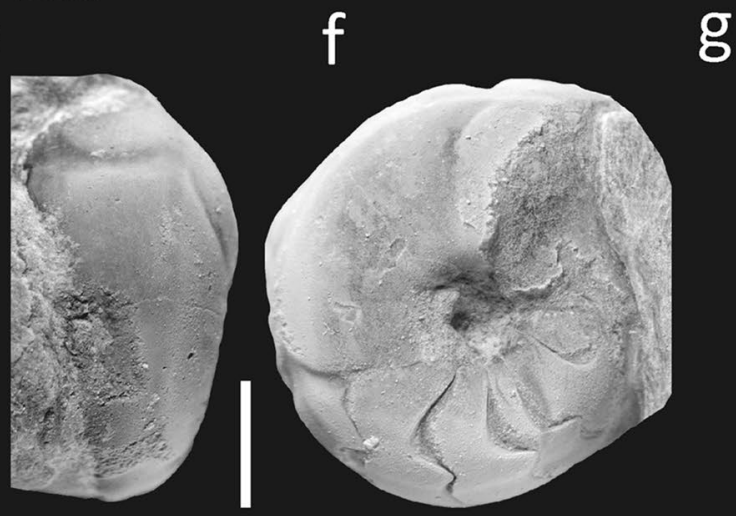

g
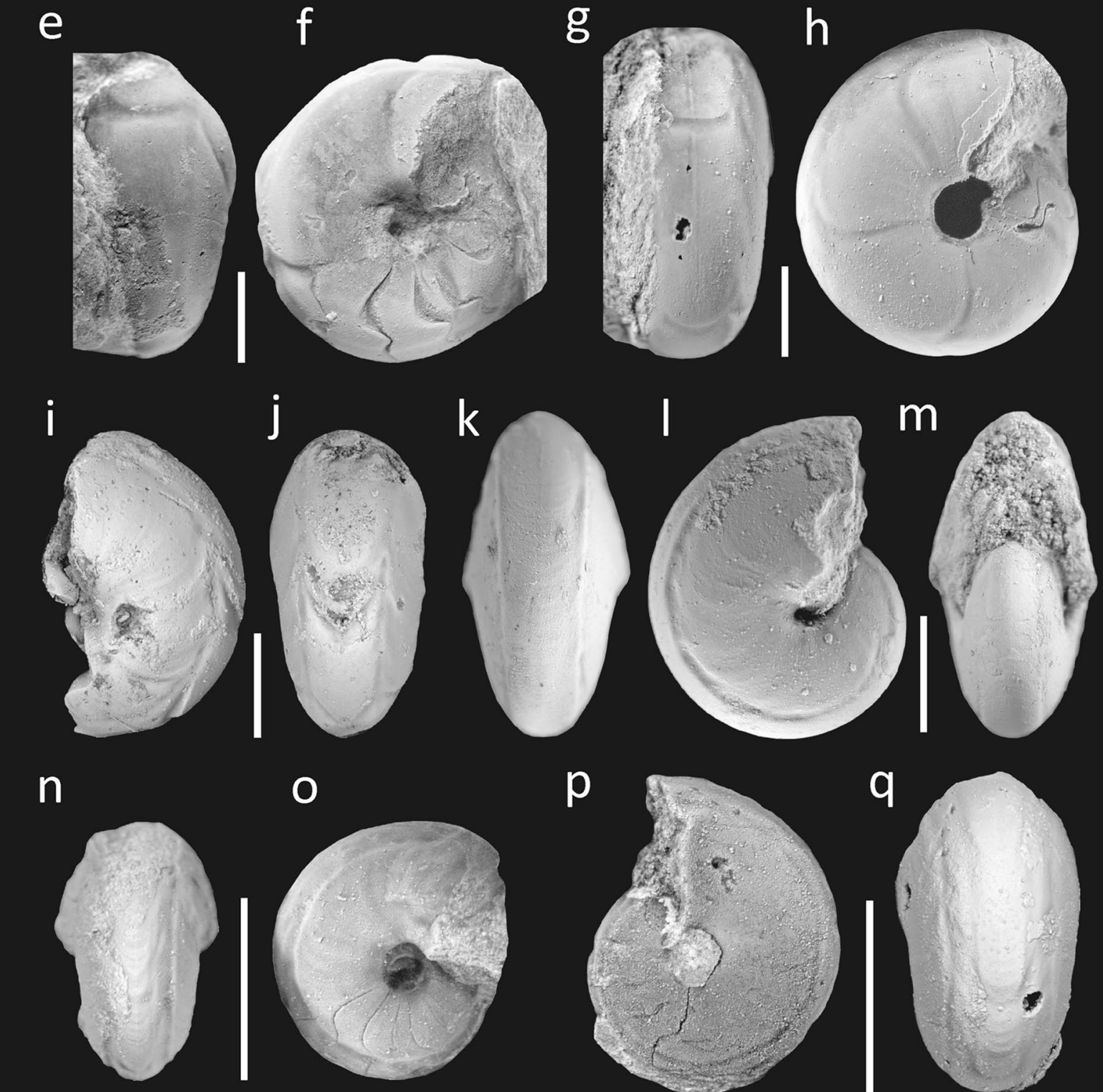

$\mathrm{p}$
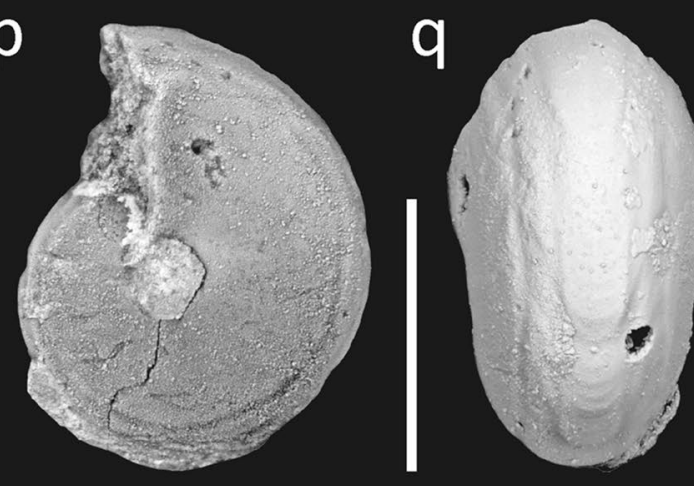
४Fig. 13 Aulatornoceratinae from the upper Frasnian Sand Formation (scale bar $2 \mathrm{~mm}$ ). a, b Aulatornoceras auris (Quenstedt, 1846), MB.C.29346.5, subadult specimen displaying typical sutures, a ventrolateral groove and strongly biconvex growth lirae forming a ventral band; ventral and lateral views, Sand $1, \times 4, \mathbf{c}, \mathbf{d}$ Aul. constrictum (Steininger, 1849), MB.C.29348.1, small specimen showing ventrolateral furrows and regular, strongly biconvex varices; lateral and ventral views, Sand A, $\times 8$, e, f Aul. constrictum (Steininger, 1849), MB.C.29348.2, showing the varices and suture with a small ventrolateral saddle; ventral and lateral, Sand A, $\times 7, \mathbf{g}, \mathbf{h}$ Aul. constrictum (Steininger, 1849), MB.C.29349.1, discoidal conch showing four varices and typical sutures; ventral and lateral views, Sand A, $\times 7$, i, j Aul. constrictum (Steininger, 1849), MB.C.29349.4, with regular varices, which are slightly more $\mathrm{V}$-shaped on the venter than in typical specimens; lateral and ventral views, Sand A, $\times 8, \mathbf{k}-\mathbf{m}$ Aul. eifliense (Steininger, 1849), MB.C.29351.1, typical specimen with high aperture, canaliculate ventrolateral grooves, and very weak ventral band; ventral, lateral and ventral views, Dombach-SanderStraße, $\times 9$, n, o Aul. aff. ventrosulcatum, specimen MB.C.29354, juvenile specimen with extremely prominent ventrolateral grooves, undulose ventral band, and very broad dorsolateral saddle; ventral and lateral views, Sand $1, \times 15, \mathbf{p}, \mathbf{q}$ Aul. aff. constrictum (Steininger, 1849), specimen MB.C.29355, displaying ventrolateral double furrows and an undulose ventral band; lateral and ventral views, Sand $1, \times 15$

extending dorsolaterally, very high, asymmetrically arched dorsolateral saddle that has a steeper mid-flank limb, deep, rounded V-shaped A-lobe, a moderately broad, subsymmetric ventrolateral saddle that remains lower than the dorsolateral saddle throughout ontogeny, and a relatively wide, short, V-shaped E-lobe.

Description. In the secondarily fragmented holotype (Fig. $2 \mathrm{~g}-\mathrm{i}$ ), the body chamber occupies at least $180^{\circ}$. The thickly tegoid, involute conch is rounded, with incipient spiral depressions creating a rounded ventral edge originating on the body chamber but lacking on the visible inner whorl. There are four, markedly biconvex varices per whorl that weaken briefly at the apex of their narrow ventrolateral projection. The ventral sinus is wide, deep, and U-shaped. The same juvenile conch form as in the holotype is seen in paratype MB.C.29358 (Fig. 2j-k), which possesses a slightly open umbilicus, shallow varices, and a rather rounded venter without any furrows.

Figure 12i-1 depicts the simple suture ontogeny based on the holotype and paratype MB.C.29358. Apart from a general increase of the suture relief, a slight dorsolateral widening of the L-lobe, a narrowing of the apex of the pronounced dorsolateral saddle, and a somewhat better rounding of the A-lobe, there is no change between 1.25 and ca. $3 \mathrm{~mm}$ wh. The ventrolateral saddle never reaches the height of the dorsolateral saddle during ontogeny. The development of the suture suggests that even very small specimens display already the characteristics required for species identifications.
Remarks. Based on the ontogenetically decreasing WER ratios, Aul. frenklerae sp. nov. may be assigned to the Aul. auris Group, where it is isolated due to the hardly developed ventrolateral furrows. At the same size, Aul. bickense is also stouter and subinvolute. In small Aul. constrictum, the A-lobe is less subtriangular and the ventrolateral furrows are well developed (e.g., Fig. 13i-j). Juvenile conchs of Aul. frenklerae sp. nov. could be mistaken for juvenile linguatornoceratids with varices (Fig. 2j-k). Among Frasnian Linguatornoceras, only the very poorly known Ling. restrictum possesses lateral varices but also a very deep, parallel-sided, tongue-shaped A-lobe, and higher whorls (WER ca. 2.40). The suture clearly differentiates our new species from Crassotornoceras and Tornoceras.

Stratigraphic range. So far only known from the upper Frasnian (UD I-K).

Aulatornoceras ventrosulcatum sp. nov.

Figures 21-m, 9j, 12m; Tables 1, 6

Etymology. After the varices ("mould sulci") that are restricted to the venter.

Holotype. MB.C.29360 (Museum für Naturkunde Berlin).

Paratype. MB.C.29361.

Type locality. Dombach-Sander-Straße, Bergisch Gladbach-Sand.

Type level. Sand Formation, upper Frasnian, UD I-K.

Diagnosis. Very small-sized; conch thickly discoidal and weakly depressed (ww/dm 0.55 and ww/wh 1.05 at $4 \mathrm{~mm} \mathrm{dm}$ ), subinvolute (uw/dm 0.15), with high whorl expansion rate (WER 2.20), tegoid, with smooth, gently rounded flanks, and narrowly rounded venter bordered by ventrolateral furrows. Growth lines strongly biconvex, with short and low dorsolateral salient, wide lateral sinus, high, narrow ventrolateral projection, and an incipient ventral band indicated by undulose, U-shaped ventral growth lines; with widely spaced, prominent $U$-shaped varices that are restricted to the venter. Suture with a broad, asymmetric, strongly arched dorsolateral saddle, a small, deep, slightly asymmetrically rounded, lingulate A-lobe, a very small and low ventrolateral saddle, and a short, rounded, divergent E-lobe.

Description. Holotype MB.C.29360 (Figs. 21-m, 12m) is a well preserved internal mould of ca. $4 \mathrm{~mm} \mathrm{dm}$. The involute and thickly discoidal conch is markedly tegoid, with a very short, rounded umbilical wall, maximum whorl width low on the very high whorl, and narrowly rounded venter marked by 
Table 11 Conch ontogeny of Aulatornoceras frenklerae sp. nov.

\begin{tabular}{|c|c|c|c|}
\hline $\mathrm{dm}$ & Conch shape & Whorl cross-section shape & Whorl expansion \\
\hline $4 \mathrm{~mm}$ & $\begin{array}{l}\text { Thinly pachyconic; involute } \\
(\mathrm{ww} / \mathrm{dm} \sim 0.65-0.70 ; \mathrm{uw} / \mathrm{dm}=0.10)\end{array}$ & $\begin{array}{l}\text { Weakly depressed; strongly embracing } \\
\text { (ww/wh 1.15-1.20; IZR } \sim 0.45 \text { ) }\end{array}$ & $\begin{array}{l}\text { High } \\
\text { (WER-2.20) }\end{array}$ \\
\hline $8 \mathrm{~mm}$ & $\begin{array}{l}\text { Thickly discoidal; involute } \\
(\mathrm{ww} / \mathrm{dm} \sim 0.50-0.55 ; \mathrm{uw} / \mathrm{dm}=0.10 \text { ) }\end{array}$ & $\begin{array}{l}\text { Weakly depressed; very strongly } \\
\text { embracing } \\
\text { (ww/wh 1.05-1.10; IZR 0.55) }\end{array}$ & $\begin{array}{l}\text { Moderate } \\
(\mathrm{WER} \sim 1.80)\end{array}$ \\
\hline
\end{tabular}

deep, U-shaped varices (four per whorl). Ventrolateral furrows are narrow and moderately distinctive. The strongly biconvex growth lines are typical for aulatornoceratids, with a high, narrow ventrolateral projection and broadly U-shaped ventral sinus. A ventral band is weakly indicated by undulose impressions of bundled growth lines (Fig. 2m). The course of the suture, especially the very small size of the ventrolateral saddle, are distinctive, and of Crassotornoceras-type.

Remarks. Aulatornoceras ventrosulcatum sp. nov. differs from the related Aul. constrictum and lower Famennian Aul. schurbuschense by its only ventral varices. It differs from associated Crassotornoceras species, such as Cr. belgicum and $\mathrm{Cr}$. crassum, by the ventrally restricted varices and the well-developed ventrolateral furrows.

Stratigraphic range. Restricted to the upper Frasnian (UD $\mathrm{I}-\mathrm{K})$.

Aulatornoceras aff. ventrosulcatum

Figures 9h, 12f, 13n-o; Tables 1, 6

Material. MB.C.29354.

Description. The juvenile specimen MB.C.29413 (Fig. 13no) is thinly pachyconic and weakly depressed (ww/dm ca. 0.60 and ww/wh 1.20 at $3 \mathrm{~mm} \mathrm{dm}$ ), subinvolute (uw/dm 0.20), and possesses a moderate whorl expansion rate (WER 1.95). The flanks and the venter are well-rounded, and the venter is bordered by distinctive canaliculate ventrolateral furrows with incipient spiral ridges (Fig. 13n). Weak varices are indicated on the venter only. Strongly biconvex growth line impressions are slightly visible on the flanks, followed by a characteristic, high ventrolateral projection, which peak lies directly inside the spiral furrow (Fig. 9h). The weak ventral band consists of undulose, slightly prominent growth line bundles, with two or three indistinctive lirae within one field (Fig. 13n). Sutures possess a generally low relief, a broadly rounded, asymmetric dorsolateral saddle embracing all of the flank until the ventrolateral furrows, a widely rounded, shallow A-lobe, a low, moderately broad, rounded ventrolateral saddle, and a small, pointed, divergent E-lobe (Fig. 12f).
Remarks. The species differs from all other aulatornoceratids by the very prominent ventrolateral furrows and its characteristic suture with a low relief, especially with the wide, non-lingulate A-lobe. Being only a juvenile specimen, the suture may change during later ontogeny but it differs markedly compared to juveniles of other Sand aulatornoceratids. MB.C.29354 resembles Aul. ventrosulcatum sp. nov. in terms of the weak ventral varices. We decided to put the species in open nomenclature until more material becomes available.

Stratigraphic range. Restricted to the upper Frasnian (UD I-K) (Fig. 3).

Acknowledgements We like to thank Helga Frenkler and Harald Steinhausen (Mineralien- und Fossilienfreunde Bayer Leverkusen e.V.) for collecting many of the specimens available for this study. The club members Inge and Michael Köhler (Leverkusen), Prof. Dr. Jürgen and Stefan Scherkenbeck (Wermelskirchen), Thomas Tix and Manfred Bundschuh (both Bergisch Gladbach) supported the excavations and collected many fossils. Traudel Fährenkemper (Münster) assisted with producing the figures. Davina Mathijssen (Münster) helped with preparing the conodont samples, Philip Herbers (Münster) assisted during the statistical analysis, and Pilar Valsera Moreno (Münster) helped with the chemical analysis via scanning electron microscopy. Helga Groos-Uffenorde (Göttingen) identified the entomozoid ostracods. Furthermore, we like to thank Dr. Doris Heidelberger (Wiesbaden) for providing holotype numbers of the Wiesbaden specimens (Sandberger collection). Lastly, we are very grateful for the helpful comments in the manuscript reviews by Dieter Korn (Berlin), Kenneth de Baets (Erlangen), Christian Klug (Zurich) and Mike Reich (Munich). The authors declare that they have no conflict of interest.

Funding Open Access funding enabled and organized by Projekt DEAL.

Open Access This article is licensed under a Creative Commons Attribution 4.0 International License, which permits use, sharing, adaptation, distribution and reproduction in any medium or format, as long as you give appropriate credit to the original author(s) and the source, provide a link to the Creative Commons licence, and indicate if changes were made. The images or other third party material in this article are included in the article's Creative Commons licence, unless indicated otherwise in a credit line to the material. If material is not included in the article's Creative Commons licence and your intended use is not permitted by statutory regulation or exceeds the permitted use, you will need to obtain permission directly from the copyright holder. To view a copy of this licence, visit http://creativecommons.org/licenses/by/4.0/. 


\section{References}

Amirie, G.H.B. 1984. Phytoplankton aus dem Frasne des Bergischen Landes, Rheinisches Schiefergebirge. Sonderveröffentlichungen des geologischen Instituts der Universität zu Köln 49(I-IV): 1-99.

Amirie, G.H.B. 1989. Sporomorphen aus dem Oberdevon (FrasneStufe) des südwestlichen Bergischen Landes, Rheinisches Schiefergebirge. Fortschritte in der Geologie von Rheinland und Westfalen 35: 107-141.

Bambach, R.K., A.J. Knoll, and S.C. Wang. 2004. Origination, extinction, and mass depletions of marine diversity. Paleobiology 30 : 522-542.

Becker, R.T. 1993a. Stratigraphische Gliederung und AmmonoideenFaunen im Nehdenium (Oberdevon II) von Europa und NordAfrika. Courier Forschungsinstitut Senckenberg 155: 1-405.

Becker, R.T. 1993b. Anoxia, eustatic changes, and Upper Devonian to lowermost Carboniferous global ammonoid diversity. In The Ammonoidea: Environment, Ecology, and Evolutionary Change, ed. M.R. House. Systematics Association Special Volume 49: $115-163$

Becker, R.T., and M.R. House. 1993. New early Upper Devonian (Frasnian) goniatite genera and the evolution of the "Gephurocerataceae". Berliner Geowissenschaftliche Abhandlungen (E: Paläobiologie) 9: 111-133.

Becker, R.T., and M.R. House. 1994. Kellwasser Events and goniatite successions in the Devonian of the Montagne Noire with comments on possible causations. Courier Forschungsinstitut Senckenberg 169: 45-77.

Becker, R.T., and M.R. House. 1999. Proposals for an international substage subdivision of the Frasnian. SDS Newsletter 15: 17-22.

Becker, R.T., and M.R. House. 2000a. Devonian ammonoid zones and their correlation with established series and stage boundaries. Courier Forschungsinstitut Senckenberg 220: 113-151.

Becker, R.T., and M.R. House. 2000b. Late Givetian and Frasnian ammonoid succession at Bou Tchrafine (Anti-Atlas, Southern Morocco). Notes et mémoires du Service géologique du Maroc 399: 27-36.

Becker, R.T., and M.R. House. 2009. Devonian ammonoid biostratigraphy of the Canning Basin. In Devonian Reef Complexes of the Canning Basin, Western Australia, eds. P.E. Playford, R.M. Hocking, and A.E. Cockbain. Geological Survey of Western Australia, Bulletin 145: 415-440.

Becker, R.T., M.R. House, and W.T. Kirchgasser. 1993. Devonian goniatite biostratigraphy and timing of facies movements in the Frasnian of the Canning Basin, Western Australia. Geological Society London, Special Publications 70: 293-321.

Becker, R.T., M.R. House, V.V. Menner, and N.S. Ovnatanova. 2000. Revision of ammonoid biostratigraphy in the Frasnian (Upper Devonian) of the Southern Timan (Northeast Russian Platform). Acta Geologica Polonica 50: 67-97.

Becker, R.T., Z.S. Aboussalam, J. Bockwinkel, V. Ebbighausen, A. El Hassani, and H. Nübel. 2004. The Givetian and Frasnian at Oued Mzerreb (Tata region, eastern Dra Valley). Documents de l'Institut Scientifique Rabat 19: 53-59.

Becker, R.T., S. Hartenfels, S. Helling, and G. Schreiber. 2016. The "Nehden Goniatite Shale" (lower Famennian, Brilon Reef Complex, NE Rhenish Massif). Münstersche Forschungen zur Geologie und Paläontologie 108: 179-195.

Becker, R.T., Z.S. Aboussalam, S. Hartenfels, A. El Hassani, and L. Baidder. 2018. Bou Tchrafine-central Tafilalt reference section for Devonian stratigraphy and cephalopod succession. Münstersche Forschungen zur Geologie und Paläontologie 110: 158-187.

Bengtson, P. 1988. Open nomenclature. Palaeontology 31(1): 223-227.

Beuth, F. 1776. Juliae et Montium subterranea sive fossilium variorum per utrumque ducatum hinc inde repertorum synatagna, in quo singular breviter recensentur ac describuntur, quade quidem collecta huisque servantur in Museo Francisco Beuth Missionarii Julio-Montensis, 1-181. Düsseldorf: Zehnpfennig.

Beyrich, E. 1837. Beiträge zur Kenntnis der Versteinerungen des Rheinischen Übergangsgebirges. Königliche Akademie der Wissenschaften zu Berlin 1837: 1-44.

Bockwinkel, J., and D. Korn. 2015. Latwe Givetian ammonoids from Oberberge (Middle Devonian; Rhenish Mountains). Neues Jahrbuch für Geologie und Paläontologie, Abhandlungen 278 (3): 351-363.

Bockwinkel, J., and D. Korn. 2017. Late Givetian ammonoids from Iserlohn and Neuenrade (northern Rhenish Mountains). Neues Jahrbuch für Geologie und Paläontologie, Abhandlungen 286 (2): 195-206.

Bockwinkel, J., D. Korn, V. Ebbighausen, and S. Graf. 2013. Late Givetian ammonoids from Hagen-Herbeck, Donnerkuhle quarry (Devonian, Rhenish Mountains). Neues Jahrbuch für Geologie und Paläontologie, Abhandlungen 270(3): 257-274.

Bogoslovskiy, B.I. 1969. Devonskiye ammonoidei. I. Agoniatity. Trudy Palaeontologicheskogo Instituta 124: 1-341.

Buch, L. von. 1832. Über Goniatiten. Abhandlungen der Königlichen Akademie der Wissenschaften zu Berlin, Physikalische Klasse 1830: 159-187.

Carmichael, S.K., J.A. Waters, P. Königshof, T.J. Suttner, and E. Kido. 2019. Paleogeography and paleoenvironments of the Late Devonian Kellwasser Event: a review of its sedimentological and geochemical expression. Global and Planetary Change, 1-125 + 1-34 in supplementary material. https://doi. org/10.1016/j.gloplacha.2019.102984.

Clarke, J.M. 1884. Die Fauna des Iberger Kalkes. Neues Jahrbuch für Mineralogie, Geologie und Paläontologie, Beilagen-Band 3: 316-411.

Clarke, J.M. 1898. The Naples fauna (fauna with Manticoceras intumescens) in western New York, 31-161 + pls. 1-9. Albany. (Preprint).

Clausen, C.D. 1969. Oberdevonische Cephalopoden aus dem Rheinischen Schiefergebirge. II. Gephuroceratidae, Beloceratidae. Palaeontographica (A: Paläozoologie, Stratigraphie) 132: 95-178.

D'Archiac, V., and M.E. De Verneuil. 1842. On the fossils of the older deposits in the Rhenish Provinces; preceded by a general survey of the fauna of the palaeozoic rocks, and followed by a tabular list of the organic remains of the Devonian System in Europe. Transactions of the Geological Society of London (second series) 6: 303-410.

Davis, R.A, N.H. Landman, J.-L. Dommergues, D. Marchand, and H. Bucher. 1996. Mature Modifications and Dimorphism in Ammonoid Cephalopods. In Ammonoid Paleobiology, eds. N.H. Landman, K. Tanabe, and R.A. Davis. Topics in Geobiology 13: 463-539.

De Baets, K., C. Klug, and D. Korn. 2011. Devonian pearls and ammonoid-endoparasite co-evolution. Acta Palaeontologica Polonica 56(1): 159-180.

De Baets, K., C. Klug, D. Korn, C. Bartels, and M. Poschmann. 2013. Emsian Ammonoidea and the age of the Hünsrück Slate (Rhenish Mountains, Western Germany). Palaeontographica (A: Paläozoologie, Stratigraphie) 299: 1-113.

De Baets, K., H. Keupp, and C. Klug. 2015. Parasites of Ammonoids. In Ammonoid Paleobiology: From Anatomy to Ecology, eds. C. Klug, D. Korn, K. De Baets, I. Kruta, and R.H. Mapes. Topics in Geobiology 43: 837-875.

De Vleeschouwer, D., A.-C. Da Silva, M. Sinnesael, D. Chen, J.E. Day, M.T. Whalen, Z. Guo, and P. Claeys. 2017. Timing and pacing of the Late Devonian mass extinction event regulated by eccentricity and obliquity. Nature Communications 8: 2268. 
Drevermann, F. 1901. Die Fauna der oberdevonischen Tuffbreccie von Langenaubach bei Haiger. Jahrbuch der Königlich Preussischen geologischen Landesanstalt und Bergakademie 21(for 1900): 99-191.

Dzik, J. 2002. Emergence and collapse of the Frasnian conodont and ammonoid communities in the Holy Cross Mountains, Poland. Acta Palaeontologica Polonica 47(4): 565-650.

Eichwald, C.E. von. 1851. Naturhistorische Bemerkungen als Beitrag zur vergleichenden Geognosie, auf einer Reise durch die Eifel, Tirol, Italien, Sizilien und Algier. Nouveaux Mémoires de la Société des Naturalistes de Moscou IX: 1-536.

Fara, E. 2001. What are Lazarus taxa? Geological Journal 36: 291-303.

Fischer, A.G., and M.A. Arthur. 1977. Secular variations in the pelagic realm. Socity of Economic Paleontologists and Mineralogists, Special Publications 25: 19-50.

Flessa, K.W., and D. Jablonski. 1983. Extinction is here to stay. Paleobiology 9: 315-321.

Fliegel, G. 1923. Die Kalkmulde von Paffrath. Jahrbuch der Preußischen Geologischen Landesanstalt XLIII(for 1922): 364-410.

Foord, A.C., and G.C. Crick. 1897. Catalogue of the fossil Cephalopoda in the British Museum (Natural History). Part III. Containing the Bactritidae, and part of the suborder Ammonoidea. 1-30, London: BMNH.

Frech, F. 1897. Lethaea geognostica. I. Theil: Lethaea palaeozoica. 2. Band. Stuttgart: Schweizerbart.

Frech, F. 1902. Über devonische Ammoneen. Beiträge zur Paläontologie und Geologie Österreich-Ungarns 14: 27-112.

Fuhrmann, A. 1954. Petrographie, Fauna und stratigraphische Stellung einiger Aufschlüsse im Oberharzer Devon, Blatt Zellerfeld und Riefensbeek. Geologisches Jahrbuch 69: 629-652.

Gatley, S.S. 1983. Frasnian (Upper Devonian) goniatites from Southern Belgium. Unpublished PhD Thesis, 1-375. Hull: The University of Hull.

Giebel, C.G. 1852. Fauna der Vorwelt mit steter Berücksichtigung der lebenden Thiere. 3. Mollusken. 1. Cephalopoden. xvi + 1-856, Leipzig: F.A. Brockhaus.

Glenister, B.F. 1958. Upper Devonian ammonoids from the Manticoceras Zone, Fitzroy Basin, Western Australia. Journal of Palaeontology 32: 58-96.

Grüneberg, H. 1925. Beiträge zur Kenntnis des Oberdevons der Herzkamper Mulde. Jahresberichte des naturwissenschaftlichen Vereins von Elberfeld 15: 48-96.

Harries, P.J., E.G. Kaufmann, and T.A. Hansen. 1996. Models for biotic survival following mass extinction. Geological Society of London, Special Publication 102: 41-60.

Hartkopf-Fröder, C., and H.M. Weber. 2016. From Emsian coastal to Famennian marine envirinments: palaeogeographic evolution and biofacies in the Bergisch Gladbach-Paffrath Syncline area (Rhenish Massif, Germany). Münstersche Forschungen zur Geologie und Paläontologie 108: 46-75.

Hartkopf-Fröder, C., U. Jux, G. Knapp, and M. Piecha. 2004. The Late Devonian of the Bergisch Gladbach-Paffrath Syncline (Ardennes-Rhenish Massif, Germany): An overview. Courier Forschungsinstitut Senckenberg 251: 7-18.

Holzapfel, E. 1895. Das obere Mitteldevon (Schichten mit Stringocephalus burtini and Maeneceras terebratum) im Rheinischen Schiefergebirge. Abhandlungen der Preußischen Geologischen Landesanstalt (Neue Folge) 16: 1-459.

House, M.R. 1958. Devonian ammonoid faunas in Southwest England. Bulletin of the Geological Society of America 69: 1587-1588.

House, M.R. 1960. Abnormal growths in some Devonian goniatites. Palaeontology 3: 129-136.

House, M.R. 1963. Devonian ammonoid successions and facies in Devon and Cornwall. Quarterly Journal of the Geological Society of London 119: 1-27.
House, M.R. 1965. A study in the Tornoceratidae: the succession of Tornoceras and related genera in the North American Devonian. Philosophical Transactions of the Royal Society of London, Series B 250: 79-130.

House, M.R. 1978. Devonian Ammonoids from the Appalachians and their bearing on international zonation and correlation. Special Papers in Palaeontology 21: 1-70.

House, M.R. 2002. Devonian (Frasnian) goniatites from Waterside Cove and Staverton Wood, South Devon. Geoscience in southwest England 10: 267-280.

House, M.R., and W.T. Kirchgasser. 1993. Devonian goniatite biostratigraphy and timing of facies movements in the Frasnian of eastern North America. In High Resolution Stratigraphy, eds. E.A. Hailwood, and R.B. Kidd. Geological Society of London, Special Publications 70: 267-292.

House, M.R., and W.T. Kirchgasser. 2008. Late Devonian Goniatites (Cephalopoda, Ammonoidea) from the New York State. Bulletins of American Palaeontology 374: 1-287.

House, M.R., and J.D. Price. 1985. New late Devonian genera and species of tornoceratid goniatites. Palaeontology 28: 159-188.

House, M.R., and W. Ziegler. 1977. The Goniatite and Conodont sequences in the early Upper Devonian at Adorf, Germany. Geologica et Palaeontologica 11: 69-108.

Hyatt, A. 1884. Genera of fossil cephalopods. Proceedings of the Boston Society of Natural History 22: 253-338.

Jablonski, D. 1986. Causes and consequences of mass extinctions: A comparative approach. In Dynamics of Extinction, ed. D.K. Elliott, 183-229. New York: Wiley.

Jux, U. 1967. Erste Funde von Graptolithen (?Palaeodictyota, Dendroidea) im Ober-Devon des Bergischen Landes (Rheinisches Schiefergebirge). Paläontologische Zeitschrift 41: 186-193.

Jux, U. 1982. Erläuterungen zu Blatt 5009 Overath. Geologische Karte von Nordrhein-Westfalen, 1:25000, Krefeld: 1-198.

Jux, U. 1984. Observations on Upper Devonian acritarch communities from the southern Bergisches Land (Rhenish Massive). Journal of Micropalaeontology 3: 35-40.

Jux, U. 1991. Fieldtrip of the Meuse-Rhine-Eurogeologists at Cologne University, 4th of May 1991 "Paffrather Mulde". Unpublished field guide, $1-30$.

Jux, U. 2008. Bergisch Gladbach-Paffrather Mulde. In Stratigraphie von Deutschland VIII. Devon. Schriftenreihe der Deutschen Gesellschaft für Geowissenschaften 52: 402-416.

Jux, U., and H. Groos. 1967. Nehden im Oberdevon der BergischGladbach-Paffrather Mulde. Neues Jahrbuch für Geologie und Paläontologie, Monatshefte 1967: 400-414.

Jux, U., and J. Krath. 1974. Die Fauna aus dem mittleren Oberdevon (Nehden-Stufe) des südwestlichen Bergischen Landes (Rheinisches Schiefergebirge). Palaeontographica (A: Paläozoologie, Stratigraphie) 147: 115-168.

Keupp, H. 1986. Perlen (Schalenkonkretionen) bei Dactylioceraten aus dem fränkischen Lias. Natur und Mensch 1986: 97-102.

Keyserling, A. 1844. Beschreibung einiger Goniatiten aus dem Domanik-Schiefer. Verhandlungen der Kayserlich-Russischen Mineralogischen Gesellschaft zu St. Petersburg 1844: 218-255.

Klapper, G. 1989. The Montagne Noire Frasnian (Upper Devonian) conodont succession. Canadian Society of Petroleum Geologists, Memoire 14(3): 449-468. (imprint 1988).

Klapper, G. 1997. Graphic correlation of Frasnian (Upper Devonian) sequences in Montagne Noire, France, and western Canada. Geological Society of America, Special Paper 321: 113-129.

Klapper, G., and W.T. Kirchgasser. 2016. Frasnian Late Devonian conodont biostratigraphy in New York: Graphic correlation and taxonomy. Journal of Paleontology 90(3): 525-554.

Kleinebrinker, G. 1992. Conodonten-Stratigraphie, Mikrofazies und Inkohlung im Mittel- und Oberdevon des Bergischen Landes. 
Sonderveröffentlichungen des geologischen Instituts der Universität zu Köln 85: 1-101.

Klug, C., and R. Hoffmann. 2015. Ammonoid Septa and Sutures. In Ammonoid Paleobiology: From Anatomy to Ecology, eds. C. Klug, D. Korn, K. De Baets, I. Kruta, and R.H. Mapes. Topics in Geobiology 43: 45-90.

Klug, C., M. Zaton, H. Parent, B. Hostettler, and A.Tajika. 2015. Mature Modifications and Sexual Dimorphism. In Ammonoid Paleobiology: From Anatomy to Ecology, eds. C. Klug, D. Korn, K. De Baets, I. Kruta, and R.H. Mapes. Topics in Geobiology 43: 253-320.

Korn, D. 2010. A key for the description of Palaeozoic ammonoids. Fossil Record 13(1): 5-12.

Korn, D., and C. Klug. 2002. Ammoneae Devonicae. Fossilium Catalogus (I: Animalia) 138: xvi + 1-375.

Korn, D., J. Bockwinkel, V. Ebbighausen, and S.A. Walton. 2013. Rare representatives in the ammonoid fauna from Budesheim (Cephalopoda, Eifel, Late Devonian) and the role of heterochrony. Neues Jahrbuch für Geologie und Paläontologie, Abhandlungen 269 (2): 111-124.

Kraft, S., D. Korn, and C. Klug. 2008. Patterns of ontogenetic septal spacing in Carboniferous ammonoids. Neues Jahrbuch für Geologie und Paläontologie, Abhandlungen 250(1): 31-44.

Maillieux, E. 1936. La Faune des Schistes de Matagne (Frasnian supérieur). Mémoires du Musée royal d'Histoire naturelle de Belgique 77: 1-74.

Manda, S., and V. Turek. 2009. Minute Silurian oncoceratid nautiloids with unusual colour patterns. Acta Palaeontologica Polonica 54: 503-512.

Matern, H. 1931a. Das Oberdevon der Dill-Mulde. Abhandlungen der Preußischen Geologischen Landesanstalt (Neue Folge) 134: 1-139.

Matern, H. 1931b. Die Goniatiten-Fauna der Schistes de Matagne in Belgien. Bulletin du Musée royal d'Histoire naturelle de Belgique 7(3): 1-15.

Miller, A.K. 1938. Devonian ammonoids of America. Special Papers of the Geological Society of America 14: 1-262.

Münster, G.G. 1832. Ueber die Planuliten und Goniatiten im Uebergang-Kalk des Fichtelgebirges, 1-38. Bayreuth: Birner.

Mutvei, H. 1967. On the microscopic shell structure on some Jurassic ammonoids. Neues Jahrbuch für Geologie und Paläontologie, Abhandlungen 129: 157-166.

Piecha, M. 2004. Late Famennian conodonts from the Refrath 1 Borehole (Bergisch Gladbach-Paffrath Syncline; Ardennes-Rhenish Massif, Germany). Courier Forschungsinstitut Senckenberg 251: 253-265.

Queins, J.F. 1988. Tentaculiten aus dem Devon des Bergischen Landes (Rheinisches Schiefergebirge). Unpublished Diploma Thesis, 1-84. Cologne: University of Cologne.

Quenstedt, F.A. 1846-49. Petrefactenkunde Deutschlands, Band 1 (Cephalopoden). Tübingen: 1-580.

Racki, G. 2005. Toward understanding Late Devonian global events: few answers, many questions. In Understanding Late Devonian and Permian-Triassic Biotic and Climatic Events: Towards an Integrated Approach, eds. D.J. Over, J.R. Morrow, and P.B. Wignall. Developments in Palaeontology \& Stratigraphy 20: 5-36.

Rakocinski, M. 2012. The youngest record of "Housean Pits" in Late Devonian ammonoids. Geological Quarterly 56 (2): 387-390.

Raup, D.M., and J.J. Sepkoski Jr. 1982. Mass extinctions in the marine fossil record. Science 215: 1501-1503.

Ribbert, K.H. 2012. Geologie im Rheinischen Schiefergebirge. Teil 2. Bergisches Land, 59-64. Krefeld: Geologischer Dienst NRW.

Roemer, F.A. 1843. Die Versteinerungen des Harzgebirges, $\mathrm{xx}+1-40$. Hannover: Hahn.

Roemer, F.A. 1850. Beiträge zur geologischen Kenntnis des nordwestdeutschen Harzgebirges. Palaeontographica 3: 1-69.
Sandberger, G., and F. Sandberger. 1850-1856. Die Versteinerungen des Rheinischen Schichtensystems in Nassau, 1-544. Wiesbaden: Kreidel \& Niedner.

Schindewolf, O.H. 1922. Einige Randbemerkungen zu E. PERNA's Abhandlung "Die Amoneen des oberen Neodevon vom Ostabhang des Südurals." Senckenbergiana 4: 185-196.

Schindewolf, O.H. 1936. Neue Gattungen tiefoberdevonischer Goniatiten. Zeitschrift der Deutschen Geologischen Gesellschaft 88 : 689-691.

Schindler, E. 1990. Die Kellwasser-Krise. Göttinger Arbeiten zur Geologie und Paläontologie 46: 1-115.

Schneider, C.L. 2018. Marine refugia past, present, and future: lessons from ancient geologic crises for modern marine ecosystem conservation. In Marine Conservation Paleobiology, eds. C.L. Tyler, and C.L. Schneider. Topics in Geobiology 46: 161-206.

Schöndorf, F. 1908. Verzeichnis der im Naturhistorischen Museum zu Wiesbaden befindlichen Originale. Abteilung für Geologie und Paläontologie. 2. Originale zu G. et F. Sandberger, Die Versteinerungen des rheinischen Schichtensystems in Nassau. Jahrbücher des Nassauischen Vereins für Naturkunde in Wiesbaden 61:39-71.

Schröter, J.S. 1777. Von den versteinten Annomiten und Terebratuliten, besonders von den Terebratuliten im Bergischen und in der Eifel. Abhandlungen verschiedener Gegenstände der Naturgeschichte 2: $335-404$.

Shannon, C.E. 1948. A mathematical theory of communication. Bell System Technical Journal 27: 379-423.

Simpson, E.H. 1949. Measurement of diversity. Nature 163: 688.

Spellerberg, I.F., and P.J. Fedor. 2003. A tribute to Claude Shannon (1916-2001) and a plea for more rigorous use of species richness, species diversity and the "Shannon-Wiener" index. Global Ecology and Biogeography 12 (3): 177-179.

Steininger, J. 1849. Die Versteinerungen des Uebergangsgebirges der Eifel. Jahrbuch des Schul-Cursus 1848/49 Gymnasium Trier, 1-34.

Steininger, J. 1853. Geognostische Beschreibung der Eifel, 1-143. Trier: Lintz.

Stigall, A.L. 2012. Speciation collapse and invasive species dynamics during the Late Devonian "Mass Extinction." GSA Today 22: 4-9.

Stridsberg, S., and V. Turek. 1997. A revision of the Silurian nautiloid genus Ophioceras Barrande. GFF 119: 21-36.

Trenkner, W. 1867. Paläontologische Novitäten vom nordwestlichen Harze. I. Iberger Kalk und Kohlengebirge von Grund. Abhandlungen der naturforschenden Gesellschaft Halle 10: 122-183.

Turek, V., and S. Manda. 2010. Variability of colour pattern and shell abnormalities in Silurian nautiloid Peismoceras Hyatt, 1884. Journal of the National Museum (Prague), Natural History Series 179: 171-178.

Weber, H.M. 2016. Die Kreishauserweiterung in Bergisch-Gladbachein Fossilfundplatz mit Überraschungen. Archäologie im Rheinland 2015: 50-51.

Weber, H.M., K.J. Herd, and C. Hartkopf-Fröder. 2013. Massensterben, Erdöl und eine neue oberdevonische Fauna aus Bergisch Gladbach-Sand. Archäologie im Rheinland 2012: 58-60.

Wedekind, R. 1910. Posttornoceras balvei n. gen. n. sp. Ein neuer Fall von Konvergenz bei Goniatiten. Centralblatt für Mineralogie, Geologie und Paläontologie 1910: 768-771.

Wedekind, R. 1913. Die Goniatitenkalke des unteren Oberdevons vom Martenberg bei Adorf. Sitzungsberichte der Gesellschaft Naturforschender Freunde zu Berlin 1: 1-77.

Wedekind, R. 1918. Die Genera der Palaeoammonoidea (Goniatiten). Mit Ausschluß der Mimoceratidae, Glyphioceratidae und Prolecanitidae. Palaeontographica 62: 85-184.

Woroncowa-Marcinowska, T. 2006. Upper Devonian goniatites and co-occuring conodonts from the Holy Cross Mountains: Studies of the polish geological institute collections. Annales Societatis Geologorum Poloniae 76: 113-160. 